\title{
Influences of Strip Mining on the Hydrologic Environment of Parts of Beaver Creek Basin, Kentucky, 1973-74
}

\section{U.S. GEOLOGICAL SURVEY PROFESSIONALPAPER 427-D}

Prepared in collaboration with the U.S. Department of the Interior, Bureau of Sport Fisheries and Wildlife and Bureau of Mines; U.S. Department of Agriculture, Forest Service and Soil Conservation Service; Department of the Army, Corps of Engineers; Commonwealth of Kentucky, University of Kentucky, Kentucky Geological Survey, Kentucky Department of Commerce, and Kentucky Department for Natural Resources and Environmental Protection

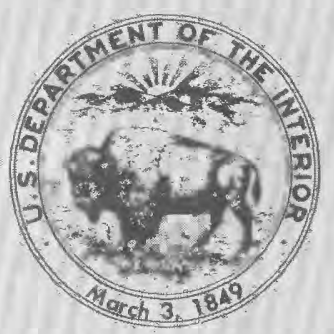




\section{Influences of Strip Mining on the Hydrologic Environment of Parts of Beaver Creek Basin, Kentucky, 1973-74}

Edited by ROBERT A. KRIEGER

H Y D R O L O I C I N F L U E N E S O F S T R I P M I N I N G

U.S. GEOLOGICAL SURVEY PROFESSIONAL PAPER 427-D

Prepared in collaboration with the U.S. Department of the Interior, Bureau of Sport Fisheries and Wildlife and Bureau of Mines; U.S. Department of Agriculture, Forest Service and Soil Conservation Service; Department of the Army, Corps of Engineers; Commonwealth of Kentucky, University of Kentucky, Kentucky Geological Survey, Kentucky Department of Commerce, and Kentucky Department for Natural Resources and Environmental Protection

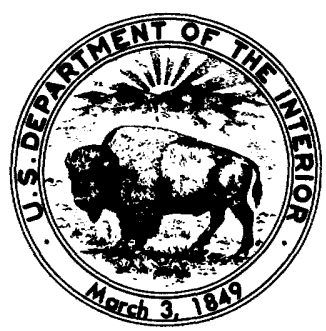




\section{DEPARTMENT OF THE INTERIOR \\ DONALD PAUL HODEL, Secretary}

\section{L.S. GEOLOGICAL SURVEY}

Dallas L. Peck, Director

Library of Congress Cataloging in Publication Data

Main entry under title:

Influences of strip mining on the hydrologic environment of parts of Beaver Creek basin, Kentucky, 1973-74.

(Hydrologic influences of strip mining) (U.S. Geological Survey professional paper ; 427-D)

"Prepared in collaboration with the U.S. Department of the Interior, Bureau of Sport Fisheries and Wildlife ... [et al.]"

Bibliography: p. $\mathbf{5 3}$

Supt. of Docs. no.: I 19.16:427-D

1. Strip mining-Environmental aspects-Kentucky-Beaver Creek Watershed. 2. Coal mines and mining-Environmental aspectsKentucky-Beaver Creek Watershed. 3. Freshwater biology-Kentucky-Beaver Creek Watershed. I. Krieger, Robert A. (Robert Albert), 1918- . II. United States. Bureau of Sport Fisheries and Wildlife. III. Series. IV. Series: Geological Survey professional paper ; 427-D

TD195.S75I54 $1984 \quad 553.7^{\prime} 09769^{\prime} 135 \quad 84-600131$

For sale by the Distribution Branch, U.S. Geological Survey 604 South Pickett Street, Alexandria, VA 22304 


\section{PREFACE}

This report is the fourth in a series on the environmental effects of strip mining of coal in Cane Branch basin, McCreary County, Kentucky. The series of reports, published by the U.S. Geological Survey as Professional Paper 427, is the product of a study by several Federal and State agencies. The physical environment of the study areas and the history of mining in the basin are described in the first report, Professional Paper 427-A (Musser, 1963). Results obtained during the study period 1955-59 and definitions of terms are given in the second report, Professional Paper 427-B (Collier and others, 1964). The third report, Professional Paper 427-C (Collier, Pickering, and Musser, 1970), describes the results of the investigation since 1955, with emphasis on the period 1959-66. With the end of the 1966 water year, the project became dormant until the 1974 water year, when it was reactivated for one year. The purpose of the reactivation was to determine the changes in the hydrologic characteristics of Cane Branch after the intervening seven years. This report describes the results of that investigation. 



\section{CONTENTS}

Preface

Summary, by Robert A. Krieger

Suggestions for further study

Conclusions

Introduction

Land use and cover conditions, by Beecher J. Hines

Precipitation and runoff, by John A. McCabe

Introduction

Instrumentation

Data available -

Runoff characteristics

Flow duration and variability - -

Peak discharges

Monthly runoff

Annual summaries of precipitation and runoff

Conclusions

Ground water, by Robert W. Davis -

Geochemistry of water, by Robert W. Davis

Introduction

Helton Branch -

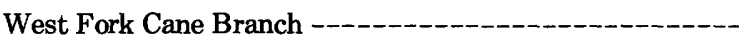

Cane Branch study area

Pools in mined areas

Tributaries of Cane Branch

Cane Branch

Comparison of chemical erosion in Cane Branch and

Helton Branch study areas -..-...-

Conclusions

Erosion and deposition, by John A. McCabe -

Introduction
Page

III Erosion and deposition-Continued

D1

3

4

4 areas
Erosion from the southwest spoil bank -_-_-_-_-_-_ D32

Sediment deposition in Cane Branch -_-_-_-__-_-_ 34

Erosion and sediment yield, by Beecher J. Hines --_-_-_-- 34

Conclusions - -

Suspended-sediment transport, by John F. Santos - Suspended-sediment transport at Cane Branch gaging station -..- 38

Storms --_-_- 42

Conclusions - -

Stream-bottom fauna, by Albert R. Jones -_-______-_- 44 Methods -_-_-_ 44 Results -_-

Comparison of accumulated bottom-fauna data --_-_-- $\quad 45$ Conclusions --_-- 45

Fish population, by John L. Boaze --_-_-_ $\quad 45$ Methods of conducting fish-population studies --.---- 46 Results of sampling fish populations --_-_-_-_-- 46 Conclusions -

Tree growth on spoils, by Thomas M. Yanosky and Robert

S. Sigafoos - Methods - -

Composition and distribution of vegetation in sampled

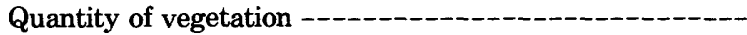

Growth rate of trees on spoils and on an abandoned farm -.-.-.- 51

Conclusions - - 52

Selected references - 53

Figures 1, 2. Maps showing:

1. Upper Beaver Creek basin study areas, stream-gaging stations, and recording precipitation stations, 1973-74

2. Location of mines and prospect areas in the Cane Branch and West Fork Cane Branch study areas, 197374 -

3-9. Graphs showing:

3. Comparison of monthly runoff for the periods of record: $A$, Cane Branch basin and $B$, Helton Branch basin ----

4. Flow-duration curves, Cane and Helton Branches -

5. Frequency of annual floods, water years 1956-74 Correlation of monthly runoffs, Cane and Helton Branches, October 1958 to September 1966 and May 1973 to September 1974

7. Changes in sulfate concentration of water in well 12 and annual precipitation, 1959-66 and 1973-74------

8. Range of dissolved solids and pH of surface waters in study areas, June 1956 to December 1959 and August 1967 to October 1974 -.

9. Relation of dissolved-solids concentration to water discharge in Helton Branch, 1956-58 and 1973-74 - - - -

10. Specific conductance and $\mathrm{pH}$ of water in pools, tributaries, and main stem of Cane Branch on September 11 and 12 ,

1973 
FiguREs 11-14. Graphs showing:

11. Decrease with time in specific conductance of water in selected pools on the southwest spoil bank ---_-_- D20

12. Relation of runoff and dissolved-solids load, 1957-66 and 1974 water years: $A$, annually, and $B$, relative to

13. Changes in relation of cumulative dissolved-solids load to cumulative runoff, Cane Branch gaging station, water years $1957-66$ and 1974

14. Relation of monthly water discharge to monthly gross dissolved-solids load in Cane and Helton Branches from October 1956 to September 1958 and from October 1973 to September 1974 --_-_---

15. Map showing sediment sampling and study sites in the Cane Branch study area, 1973-74 -_..--

16. Profiles of the floor of gully 14 showing erosion from August 1959 to March 1974

17. Contour map of area 11, an area on the southwest spoil bank drained by a large gully, February to March 1974

18. Profiles of upper surface of spoil bank, area 11, section A-A', showing erosion from October 1958 to March 1974 ------

19, 20. Comparative photographs showing:

19. Channel development, upper surface of spoil bank, area 11

20. Gully development in area 11

21, 22. Contour maps of:

21. Area 12, a rilled and terraced part of the southwest spoil bank, February 1974

22. Area 1, a reach of Cane Branch channel, February 1974

23. Cross-section and longitudinal profiles of Cane Branch in area 1

24. Comparative photographs of the Cane Branch channel in area 1

25. Longitudinal profile of Cane Branch in area 2

26-29. Graphs showing:

26. Relation of suspended-sediment concentration to precipitation and water discharge, Cane Branch near Parkers Lake, October 3, 1973 -_.

27. Variation in suspended-sediment discharge and water discharge for Cane Branch and Parkers Lake, by water year -

28. Relation of suspended-sediment concentration to precipitation and water discharge, Cane Branch near

Parkers Lake, March 21, 1974 - Relation of suspended-sediment discharge to water discharge by storms, Cane Branch near Parkers Lake -
29.

30, 31. Maps showing:

30. Location of fish-sampling stations and distribution of fish within the Beaver Creek basin, 1973-74 --_----

31. Cane Branch basin and location of forest plots

32. Graph showing basal area of all woody stems 1 inch or larger in diameter for all plots

\section{TABLES}

TABLE 1. Summary of annual precipitation, runoff, change in ground-water storage contributing to base flow, and evapotranspiration - -

2. Chemical analyses of common constituents in samples of ground water from well $12,1967-71$ and $1973-74$

3. Chemical analyses of common constituents in samples from Helton Branch at Greenwood, 1973-74 --_-_-

4. Chemical analyses of total and dissolved minor elements in samples from Heton Branch at Greenwood, 1973-74 -.-.-----

5. Chemical analyses of common constituents in a sample from West Fork Cane Branch, 1973

6. Chemical analyses of minor elements in a sample from West Fork Cane Branch near Parkers Lake, 1973

7. Chemical analyses of common constituents in samples from selected pools in Cane Branch study area, 1973 --_-_----

8. Chemical analyses of minor elements in samples from selected pools in Cane Branch study area, 1973 -.--

9. Chemical analyses of common constituents in samples from selected tributaries of Cane Branch, 1973 --

10. Chemical analyses of minor elements in samples from selected tributaries of Cane Branch, 1973

11. Chemical analyses of common constituents of samples from Cane Branch near Parkers Lake, 1967-74 -

12. Chemical analyses of total and dissolved minor elements in samples from Cane Branch near Parkers Lake, 1973-74 --------

13. Annual runoff, gross annual loads, and annual mean concentrations of selected chemical constituents at Cane Branch near Parkers Lake gaging station, water years 1957-66 and 1974-

14. Dissolved solids and sulfate concentrations and loads, Cane Branch near Parkers Lake, October 1973 to September 1974 ----

15. Dissolved solids and sulfate concentrations and loads, Helton Branch at Greenwood, October 1973 to September 1974 -------

16. Rates of chemical degradation and runoff in the Cane and Helton Branches study areas, water years 1957-62 and 1974 -----

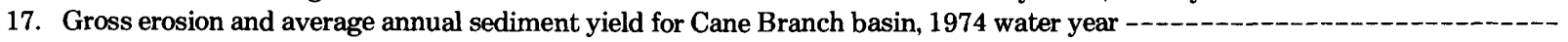

18. Gross erosion and average annual sediment yield for Helton Branch basin ---

19. Gross erosion and average annual sediment yield for West Fork Cane Branch basin -_-

20. Summary of sediment discharge by water year, Cane Branch near Parkers Lake

21. Summary of suspended sediment discharge by month, Cane Branch near Parkers Lake 
TABLE 22. Average number of bottom-fauna organisms per square foot in tributaries to Beaver Creek, June 1974

23. Average number per square foot of Ephemeroptera, Trichoptera, and Coleoptera in Little Hurricane Fork and Hughes

Fork below the mouth of Cane Branch in selected months, 1956-62, 1964, and 1974

24. Fish production in affected and reference streams, Beaver Creek basin, 1973-74

25. Comparison of the standing stocks of the affected and reference streams within the Beaver Creek basin, 1973-74 --..--_---

26. Relative abundance of various species of fish collected from the affected and reference stations within the Beaver Creek study area, 1973-74-

27. Mean number and mean basal area of species in four areas

28. Growth rates of pine trees on the young mine spoils and on abandoned farmland -

29. List of common and scientific names of woody species -

30. Discharge and runoff at the Cane Branch near Parkers Lake stream-gaging station -_-_-_-_-_-_-_-

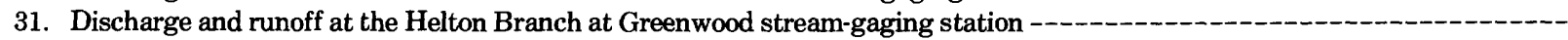

32. Annual maximum discharges for Cane Branch near Parkers Lake

33. Annual maximum discharges for Helton Branch at Greenwood -

34. Annual maximum discharges for West Fork Cane Branch near Parkers Lake -

35. Precipitation at recording gages, October 1966 to September 1974

36. Maximum precipitation amounts recorded in Cane Branch basin during selected storms

\section{CONVERSION FACTORS}

[Factors for converting inch-pound units to metric units are shown to four significant factors]

Inch-pound units

acres

acre-ft (acre-feet)

$\mathrm{ft}^{3} / \mathrm{s}$ (cubic feet per second)

ft (feet)

gal (gallons)

in (inches)

$\mathrm{mi}$ (miles)

$\mathrm{mi}^{2}$ (square miles)

tons (short)

tons $/ \mathrm{mi}^{2}$ (tons per square mile)
Multiply by

0.004047

0.001233

0.02832

0.3048

3.785

25.4

1.609

2.590

0.9072

0.350
Metric units

$\mathrm{km}^{2}$ (square kilometers)

$\mathrm{hm}^{3}$ (cubic hectometers)

$\mathrm{m}^{3} / \mathrm{s}$ (cubic meters per second)

m (meters)

L (liter)

$\mathrm{mm}$ (millimeters)

km (kilometers)

$\mathrm{km}^{2}$ (square kilometers)

$t$ (metric tons)

$\mathrm{t} / \mathrm{km}^{2}$ (metric ton per square kilometer) 



\title{
INFLUENGES OF STRIP MINING ON THE HYDROLOGIC ENVIRONMENT OF PARTS OF BEAVER GREEK BASIN, KENTUCKY, 1973-74
}

\author{
Edited by ROBERT A. KRIEGER
}

\author{
SUMMARY \\ By Robert A. Krieger
}

Coal was strip mined in the Beaver Creek basin, McCreary County, Ky., intermittently from 1955 to 1959. Three small areas of Cane Branch, West Fork Cane Branch, and Helton Branch basins in the headwaters of Beaver Creek were studied for changes resulting from this mining. About 10 percent of the Cane Branch study area had been mined, and the West Fork Cane Branch basin had been prospected. The Helton Branch study area, which had not been mined, was used as a control. Investigations of the three areas were made during the years 1955-66, and the areas in Cane Branch and Helton Branch basins were restudied in 1973-74. It was originally proposed that 1-year studies of the effects of mining be activated every 10 years in order to develop information on the rate of recovery of the area. However, because of the possibility that part of the study area would be declared a Wilderness Area, it was necessary to reactivate the project in 1973 rather than in 1976. Under Wilderness Area classification, further access and data-acquisition activities would be severely constrained. Also, the spoil bank would be regraded and seeded to restore the mined area to a more natural state.

Mining in the Cane Branch basin significantly changed the chemical quality of the surface and ground waters, increased the sediment yield from the basin, and adversely affected the aquatic life in the streams. The picture that emerged from the wet water year 1974 was that of a drainage basin and its stream gradually recovering toward its premining quality.

In the 1974 water year, heavy rainfall on the basins produced runoff from November to January that was more than twice as great on the whole, as the average runoff for these months. Runoff was about 54 percent of precipitation for Cane Branch basin and 64 percent for Helton Branch basin. Runoff records for gaging stations on Cane and Helton Branches showed marked differences. However, the effects of strip mining could not be separated from the usual factors in the hydrologic environment that also affect the flow regimen.

Records for the earlier period of study indicated that at higher flows the discharge for Cane Branch generally exceeded the discharge for Helton Branch. The reverse was true at lower flows. During 1973-74, Helton Branch discharge generally exceeded Cane Branch discharge throughout the range of discharge, except for the maximum for the year. At durations of less than about 20 percent, Helton Branch flows exceeded Cane Branch flows by as much as 30 percent. This perceptible shift to higher runoff in Helton Branch during 1973-74 could be due to an inherent difference in flows (in years of heavy precipitation) that existed before strip mining began. However, small mountain streams are some of the most difficult to measure accurately, especially at high flows. It is possible that the differences in flood discharges between the two basins are within the margin of error.

No significant trends in ground-water levels were observed other than normal seasonal variations in response to rainfall and evapotranspiration.

Cane Branch became a highly mineralized acid stream in early 1956 as a result of intermittent strip mining of coal in the basin during the periods May 1955 to April 1956 and December 1958 to August 1959. The increase in concentrations of dissolved solids, sulfate, and acidity in the water of Cane Branch was significant. These concentrations began to decrease in 1960 and by 1962 had reached the 1957 level. Although fluctuations of annual mean concentration due to climatic variations made it difficult to identify a definite trend for the period 1962-66, it appeared there was little change in the rate of chemical weathering or 
in the chemical composition of the water in Cane Branch during these 5 years of the study.

Cane Branch in water year 1974 transported out of the basin a dissolved-solids load of 237 tons $/ \mathrm{mi}^{2}$ (tons per square mile), about 57 percent of the load for the high runoff year 1960 and somewhat less than the load for water year 1962, also a high runoff year. Nearby Helton Branch in water year 1974 transported about 66 tons $/ \mathrm{mi}^{2}$ of dissolved-solids load.

Corrected for the dissolved solids in precipitation during the period 1957-62, Cane Branch transported a net dissolved-solids load of about 1,370 tons per square mile of dranage area, and Helton Branch transported a net load of about 111 tons per square mile of drainage area. In water year 1974, the net loads of dissolved solids were 202 tons $/ \mathrm{mi}^{2}$ and 35 tons $/ \mathrm{mi}^{2}$ for Cane Branch and Helton Branch areas, respectively. The rate of chemical degradation for the Cane Branch area was about 12 times greater than that for the Helton Branch area during the 6-year period and about 6 times greater in the wet water year 1974 .

As an indication of the quality of the water in the Cane Branch study area prior to the April 1955 mining, several small streams unaffected by mining have had a median dissolved-solids concentration of $20 \mathrm{mg} / \mathrm{L}$ (milligrams per liter) and a $\mathrm{pH}$ range of 5.2 to 7.6 units. From June 1956 to December 1959, the dissolved-solids concentration of Cane Branch water increased, ranging from 76 to $1,460 \mathrm{mg} / \mathrm{L}$ with a median value of $310 \mathrm{mg} / \mathrm{L}$. Sulfate made up about 70 percent of the dissolved solids, ranging in concentration from 46 to $1,220 \mathrm{mg} / \mathrm{L}$. In contrast, from August 1967 to October 1974 the concentration of dissolved solids narrowed to a range of 40 to $366 \mathrm{mg} / \mathrm{L}$ while sulfate ranged from 21 to $226 \mathrm{mg} / \mathrm{L}$.

Helton Branch, which drains a nearby similar basin that had not been mined, changed little in water quality from 1956 to 1974 , remaining low in mineral content and with a nearby neutral $\mathrm{pH}$. In the 1973-74 study, the discharge-weighted average concentration for dissolved solids was about $25 \mathrm{mg} / \mathrm{L}$ and the median value for sulfate was about $7 \mathrm{mg} / \mathrm{L}$.

Water in pools formed by the strip mining of coal has become less mineralized. Since 1956-59, some pool waters in the southwest spoil bank have shown a tenfold reduction in sulfate concentration and specific conductance and are less acidic. By 1973, specific conductance of some pool waters had begun to level off at about 100 micromhos, or about that of natural surfacewater drainage. The exceptions are the metals aluminum, iron, and manganese, which continue, collectively, to exceed $1 \mathrm{mg} / \mathrm{L}$ in acid waters. The rapid rate of chemical degradation in the Cane Branch area is attributed largely to the strip mining of coal in 1955-56 and 1958-59, which exposed pyrite and other unweathered minerals to agents of weathering and erosion.

There is compelling evidence that erosion of the spoil banks and deposition of sediment in the Cane Branch channel is decreasing. Erosion and downcutting of gullies on the southwest spoil bank have continued, but at a lower rate since the 1966 surveys. The mean degradation along the profiles of gullies 14 and 15 averaged $0.24 \mathrm{ft} / \mathrm{yr}$ (feet per year) during the period 1966-74, well below the value during the 1959-62 period. For area 12, a rilled and terraced part of the southwest spoil bank, the 1974 survey indicated an average net fill (sediment deposit) on the area of less than $0.1 \mathrm{ft}$ since the 1966 survey, well within the margin of measurement error.

The February 1974 survey showed that the channel of Cane Branch in the lower reaches of the study area (area 1) has been scoured since 1966 and possibly has undergone a number of scour and fill cycles. The channel appears to be returning to its condition prior to strip mining. Material eroded from the spoil piles and deposited in the channel from 1958 to 1966 has been transported out of the study area and redeposited farther downstream. Gross erosion or soil loss in the 0.67-square-mile area of Cane Branch basin is about $2,400\left(\right.$ tons $\left./ \mathrm{mi}^{2}\right) / \mathrm{yr}$, and the measured sediment yield at the gaging station is $1,170\left(\right.$ tons $\left./ \mathrm{mi}^{2}\right) / \mathrm{yr}$. Thus, about 49 percent of the sediment eroded is delivered to the streams. The bulk of the soil loss, 1,500 tons, or nearly 94 percent, comes from the spoil piles.

These observations are in sharp contrast with the undisturbed (unmined) Helton Branch basin, where the gross erosion is about $796\left(\right.$ tons $\left./ \mathrm{mi}^{2}\right) / \mathrm{yr}$ and the measured sediment yield is 207 (tons $\left./ \mathrm{mi}^{2}\right) / \mathrm{yr}$. Thus, Cane Branch basin has an erosion rate more than three times and a sediment yield more than five times the rates for Helton Branch. With only about 2 percent of West Fork Cane Branch acreage in mine spoil, there is no apparent increase in erosion or sediment yield in comparison with values compiled for Helton Branch basin.

The annual suspended sediment yield from Cane Branch ranged from 617 to 3,010 tons $/ \mathrm{mi}^{2}$ during the period 1957-66. The highest weighted mean concentration was $1,640 \mathrm{mg} / \mathrm{L}$. In 1974 , the suspended sediment yield was 1,170 tons $/ \mathrm{mi}^{2}$, with a weighted mean concentration of $416 \mathrm{mg} / \mathrm{L}$.

Thus, the current data (1973-74) support the conclusion that sufficient revegetation has taken place in Cane Branch to cause a decrease in suspended sediment yields. The discharge-weighted concentration of suspended sediment in 1973-74 was the minimum for the study years, while the discharge was a maximum. This significant change in water discharge versus sediment discharge indicates that less material is readily available for transport out of the basin. 
Bottom-fauna data from the Beaver Creek basin for the years 1956-66 and 1974 reveal that the acid water and the sediment resulting from the strip mining of coal have resulted in a loss of invertebrate bottom fauna in Cane Branch and Hughes Fork. In Helton Branch, about 24 organisms per square foot of stream bottom were present, while in an equal area of stream bottom in Cane Branch only 1 organism was present.

Results of fish-population sampling in Beaver Creek basin in 1973-74 indicate that Cane Branch remains devoid of fish owing to low $\mathrm{pH}$ of the water draining from the strip-mined areas. Comparison of the standing stock in the reference streams within Beaver Creek basin with stock in Cane Branch and Lower Hughes Fork seems to indicate that surface mining is responsible for depressing or eliminating the fish population in the streams receiving the acid runoff. The reference streams were supporting 3.7 times as many fish by number and 2.5 times as many fish by weight as the affected streams. The fish population in Hughes Fork below the confluence with Cane Branch was severely restricted in both numbers and species. However, natural stream recovery appeared to be taking place, as indicated by the increase in fish population in the lower section of Hughes Fork of Beaver Creek.

The number, form, and density of woody vegetation in various parts of the Cane Branch study area indicate the overall negative influence of strip mining on woody vegetation. The significantly smaller amount of vegetation on the young mine spoils than on the older mine spoils, abandoned farmland, and upland probably is related to poorer site conditions on the younger spoils. Basal area of pines on the spoils is less than on the abandoned farmland because fewer trees per unit area grow on the spoils, as reflected in density values. Although trees on the young spoils are younger than trees on the abandoned farmland, time alone cannot account for the differences in quantity of vegetation. Comparable growth rates of trees on the two sites indicate that, in places on the spoils, trees grow as well as on nonmined areas.

Reforestation of those parts of the mined areas now inadequately forested will undoubtedly continue, and future studies are needed to document their rate of recovery.

\section{SUGGESTIONS FOR FURTHER STUDY}

Although it is unlikely that another 1-year study will be made, the following studies and practices would be useful. These suggestions are phrased in terms of the conclusions reached from the 1-year resumption of data collection in Beaver Creek basin.

1. A minimum continuing program to monitor longterm change should include a daily record of water discharge at the Cane Branch and Helton Branch gaging stations, records of monthly and maximum precipitation at the two recording precipitation stations in Cane Branch basin (storm events exceeding 2 inches), seasonal measurement of water level and sulfate content of well 12, and chemical analysis of water at pools 2,3 , and 9 in the mined area. The program should also include, for both Cane Branch and Helton Branch, at least quarterly chemical analysis, a resurvey of areas 1 and 2 in Cane Branch Channel and areas 11 and 12 and gullies 14 to 17 on the southwest spoil banks, an update of the annual gross erosion estimate for Cane Branch and Helton Branch, and measurement of monthly and annual suspended sediment discharge for Cane Branch and Helton Branch. In addition, the study should include a summer-period survey of stream-bottom fauna and fish population for a section of Cane Branch and Helton Branch above and below the affected areas, and a resurvey of reforestation and growth rates of trees on selected mine spoils.

2. The Beaver Creek study was started after strip mining had begun in Cane Branch basin. The lack of hydrologic data for Cane Branch before mining made it necessary to choose another, nearby basin as a control against which the hydrologic character of Cane Branch basin after mining could be compared. The major criteria for choosing a control basin should include: (1) the control basin must be as similar as possible to the study basin and (2) the control basin should not be altered during the study. Wherever and whenever possible, the study basin and the control basin should be investigated and data collected for 2 or 3 years before strip mining is begun.

3. Stream-discharge stations on small streams in mountainous terrain are often very difficult to operate, making it difficult to obtain data within normal standards of accuracy. The flashy character of the stormflows, the very low discharges during base flows, and difficulty of access can produce data of less accuracy than desirable unless special data collection techniques are used. In this instance, the water-discharge data could have been more accurate had a flume and a broadbase weir been used for increased sensitivity at low flows and floodflows, respectively. Floodflows would still be a problem requiring study of best placement of intakes and instrumentation for measurement of high flow. Ease of access during storms is an important factor in devising a data-collection program.

4. If another study of this kind is made, it would be informative to measure the acidity or $\mathrm{pH}$ of the 
spoil material in a number of areas to a depth of $3 \mathrm{ft}$ to document the leaching of acidic material from the surface layer for comparison with the rate and extent of revegetation.

\section{CONCLUSIONS}

The intent of the Beaver Creek study was to document the effects of the strip mining of coal in mountainous terrain and restoration methods normal for the time. This was accomplished, as shown by the numerous data given in this and other chapters in U.S. Geological Survey Professional Paper 427. The data support several overall conclusions, as follows:

1. The method of piling the overburden without any specific attempt to bury the sulfurous minerals was a major factor in promoting the intensity and duration of acid mine drainage to the streams.

2. The method of piling the overburden and allowing natural revegetation to reclaim the area delayed the recovery process.

3. Drift mining of the coal seam in the strip pit seemed to have no measurable effect on either erosion or production of mine acids. If there was any effect, it was masked by the load of sediment and acid from the spoil bank.

4. The primary products from the strip mining of coal harmful to the environment are sediment and mineral acids. These in turn affect the biological component of the environmental system. Both sediment and acidity can be qualitatively and quantitatively measured with a reasonable degree of accuracy.

5. Under the conditions that prevailed in this study, sediment yield decreased more rapidly than did the production of mineral acids.

6. The strip mining of coal in Cane Branch basin had no measurable effect on the total flow of Cane Branch. However, the effect of increasing erosion and fluvial sediment, degrading the chemical quality of the water, and depressing the biological system was highly significant.

7. Measurement of the effects of strip mining is best done by establishing baseline data, by a few years of environmental study preceding the mining, for comparison with postmining data.

8. The effect on the ground-water system in the Cane Branch basin was negligible compared with the effect on the surface-water and the biological systems.

9. The unordered method of piling and leveling of the spoil material produced some sorting of the raw spoil into pockets of highly acidic and of low- or non-acidic material. This resulted in some areas of surface material that were soon suitable for natural revegetation and other surface areas that were very hostile, for long periods, to any kind of revegetation. The obvious conclusion is that the practice, sometimes used in strip-mining reclamation, which separates and then restores soil and soil material as the top layer for promoting reclamation, is indeed a good one.

\section{INTRODUCTION}

A study of the hydrologic effects of the strip mining of coal with very little subsequent reclamation commenced in 1955 in the basin of Cane Branch, a tributary of Beaver Creek in McCreary County, southern Kentucky. At the same time, a comparative study was made in the basin of Helton Branch, another, nearby tributary of Beaver Creek, where mining had not taken place (see fig. 1).

The results of these studies through the 1966 water year have been documented in three earlier reports (Musser, 1963; Collier and others, 1964, 1970). The project was essentially closed down in 1966; however, the three gaging stations in Cane Branch, West Fork Cane Branch, and Helton Branch basins and the precipitation gages in Cane Branch and Helton Branch basins continued to operate. The original plan called for reactivation of the study every 10 years after 1966 to assess the long-term effects of strip mining. However, because the U.S. Forest Service was contemplating reclamation work in the Cane Branch basin, the Interagency Beaver Creek Work Group Committee met May 19, 1973, and decided to reactivate the project for an additional year of study beginning July 1, 1973. Actually, data collection extended over a 15 -month period ending September 30, 1974.

Agencies that participated in the most recent study were U.S. Forest Service; U.S. Army Corps of Engineers; U.S. Fish and Wildlife Service; U.S. Soil Conservation Service; U.S. Geological Survey; U.S. Bureau of Mines; Kentucky Department of Commerce; Kentucky Department for Natural Resources and Environmental Protection; University of Kentucky; Kentucy Geological Survey; and Kentucky Reclamation Association.

The Interagency Beaver Creek Work Group Committee was chaired by E. L. Hendricks, retired chief hydrologist, U.S. Geological Survey. A. K. Trethow, Topographic Division, U.S. Geological Survey, provided the resurveys of the areas and gullies on the southwest spoil bank and in the Cane Branch channel.

In preparing this chapter of Professional Paper 427, it was assumed that the reader would be reasonably familiar with basic characteristics of the area and with the progress and findings of the study that were described in the three previous chapters. Therefore, no 


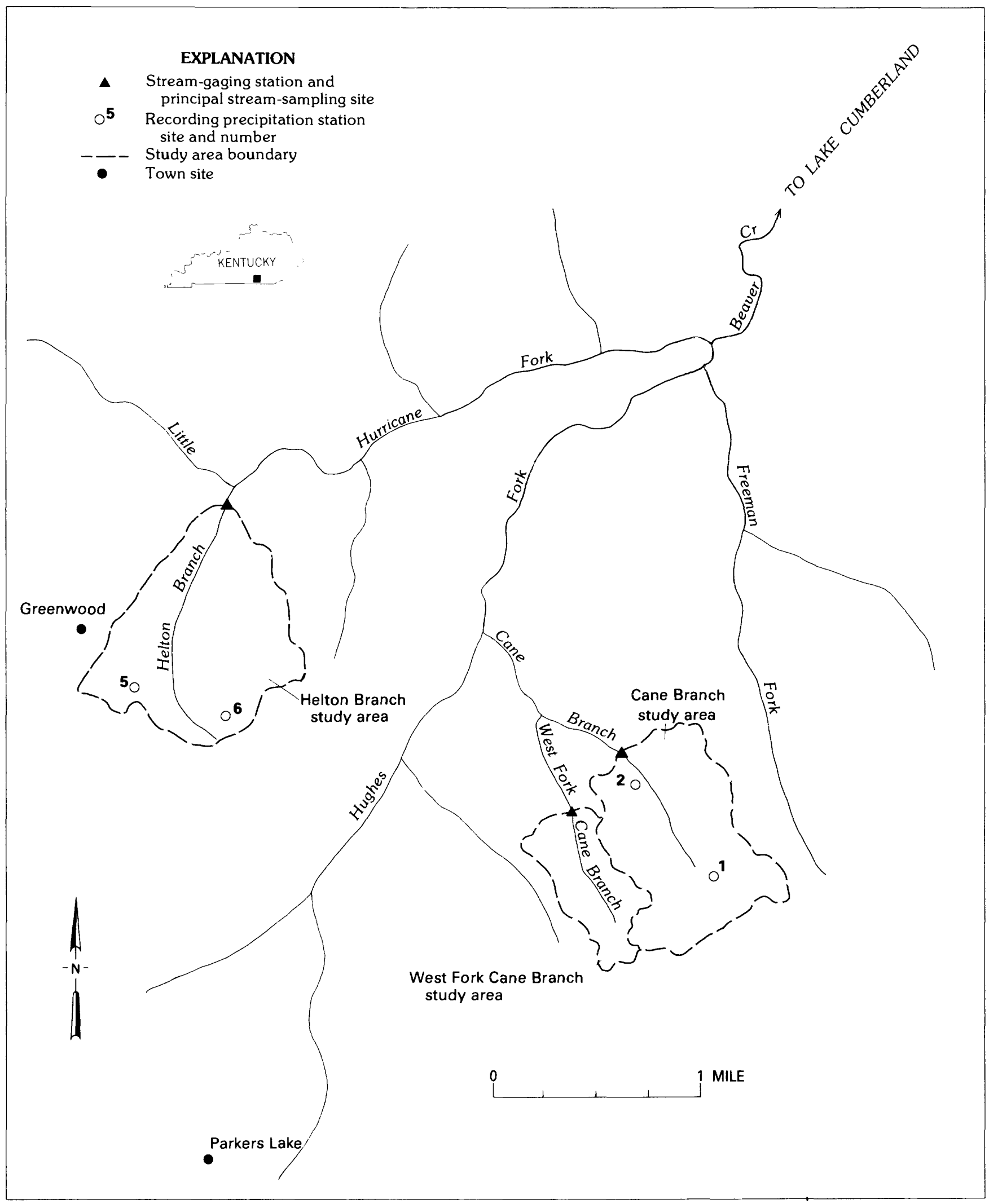

FIGURE 1.-Upper Beaver Creek basin study areas, stream-gaging stations, and recording precipitation stations, $1973-74$. 
attempt was made to describe the geology of the three study areas or the soils, mining activities, hydrology, and other details. However, it seemed desirable to provide some simple sketch maps for orientation purposes and to include some previous material in instances in which data and records were extended to include September 1974. Because so many changes were made in the spoil banks, roads, and vegetation cover upon conversion of parts of the study areas to Wilderness Area classification, no further work is intended. Furthermore, the Wilderness Area classification forbids many of the activities required to continue the study.

\section{LAND USE AND COVER CONDITIONS}

\author{
By Beecher J. Hines \\ U.S. Soil Conservation Service
}

The undisturbed areas along Helton Branch have remained about the same, or perhaps show some improvement, since 1966 . The one farm that lies partially within the watershed has converted from rotation corn-meadow to permanent grass. The sod is an excellent stand of almost pure fescue. Cultural changes include the construction of one small dwelling and the presence of one mobile home situated on land that was previously idle.

U.S. Highway 27 has been relocated since the last study. Most of the roadbanks have been successfully seeded to fescue, resulting in an excellent stand of grass on the banks, shoulders, and berms. The remaining bare areas consist of steep cut banks that average $8 \mathrm{ft}$ in height and approximately $1,600 \mathrm{ft}$ in length. These bare roadbanks constitute sediment-source areas to Helton Branch.

The Cane Branch basin has not been disturbed since the March 1966 study. Ground cover in the woods may be slightly improved in 1974 owing to the added growth of the shrubs, forbs, and young trees. The abandoned fields and idle land now have a dense stand of young trees, weeds, and blackberry briars.

There is some variation in the cover conditions on the spoil banks. Most of the high walls remain bare, but better vegetative cover has been established on some of the spoil banks than on others.

The mined area (fig. 2, northeast strip mine) in the northeastern part of Cane Branch basin (Musser, 1963, pl. 3, fig. 1) includes about 13 acres. The younger spoil (4.2 acres) has Virginia pines on about 35 percent of the area. Accumulation of pine needles provides good cover on about 10 percent of the 4.2 acres. The older mine spoil ( 8.8 acres) has 55 percent vegetative cover; Virginia pine is dominant, and there are a few oak, maple, and shrubs. Common lespedeza grows on some spoil areas along with wild grasses and weeds.
The spoil area of the east strip mine covering 4.2 acres (fig. 2) had the best vegetative cover of any site in 1974. This area is in a saddle or gap and has more gentle slopes than the other spoil areas. A dense growth of weeds, wild legumes, and grasses cover the outer perimeter, and only 10 percent of the spoil area remains bare. Virginia pine dominates the tree species, but shortleaf pine, maple, poplar, oak, and other trees are present, with a mixture of wild grasses and legumes.

The small, 1.1-acre mine spoil and prospect area (fig. 2, strip mine, 1947) in the southern part of Cane Branch basin (Musser, 1963, pl. 3, fig. 1) has a fairly good cover of wild legumes, weeds, and grasses under pine trees. Approximately 20 percent of this area remains bare.

The largest mined area (Musser, 1963, pl. 3, fig. 1), consisting of 24.8 acres (fig. 2, southwest strip mine) has almost no vegetation other than Virginia pines. Salt crystals or salty deposits are visible where surface water has evaporated. Nearly all the trees are on the spoil that has been leveled or on the slopes toward the high wall. The outslopes are almost bare, perhaps 65 percent of the total. Pine needles cover about 30 percent of the portion shaded by trees.

The three small coal prospecting areas (fig. 2), one of which is in the West Fork Cane Branch basin watershed, have about 60 percent ground cover (1974), with wild legumes, weeds, and grasses growing between the trees to provide fair to good soil cover.

\section{PRECIPITATION AND RUNOFF \\ By John A. McCabe \\ U.S. Geological Survey}

\section{INTRODUCTION}

Precipitation and runoff data were collected during the 1974 water year as support records for other phases of the project. Thomas (in Collier and others, 1964, p. B4-B19) and McCabe (in Collier and others, 1970 , p. C5-C9) determined differences in runoff characteristics between the Cane Branch and Helton Branch basins. Thomas concluded that the Cane Branch runoff data probably reflected, to an unknown degree, the changes in land cover and use resulting from strip mining in the basin. McCabe was unable to determine any progressive change in runoff characteristics that could be related to the history of mining in the area, within the limits of error of the runoff data.

\section{INSTRUMENTATION}

The Cane Branch gaging station had been converted to a crest-stage/low-flow partial-record station on September 30,1966 . With the reactivation of the project, 


\section{EXPLANATION}

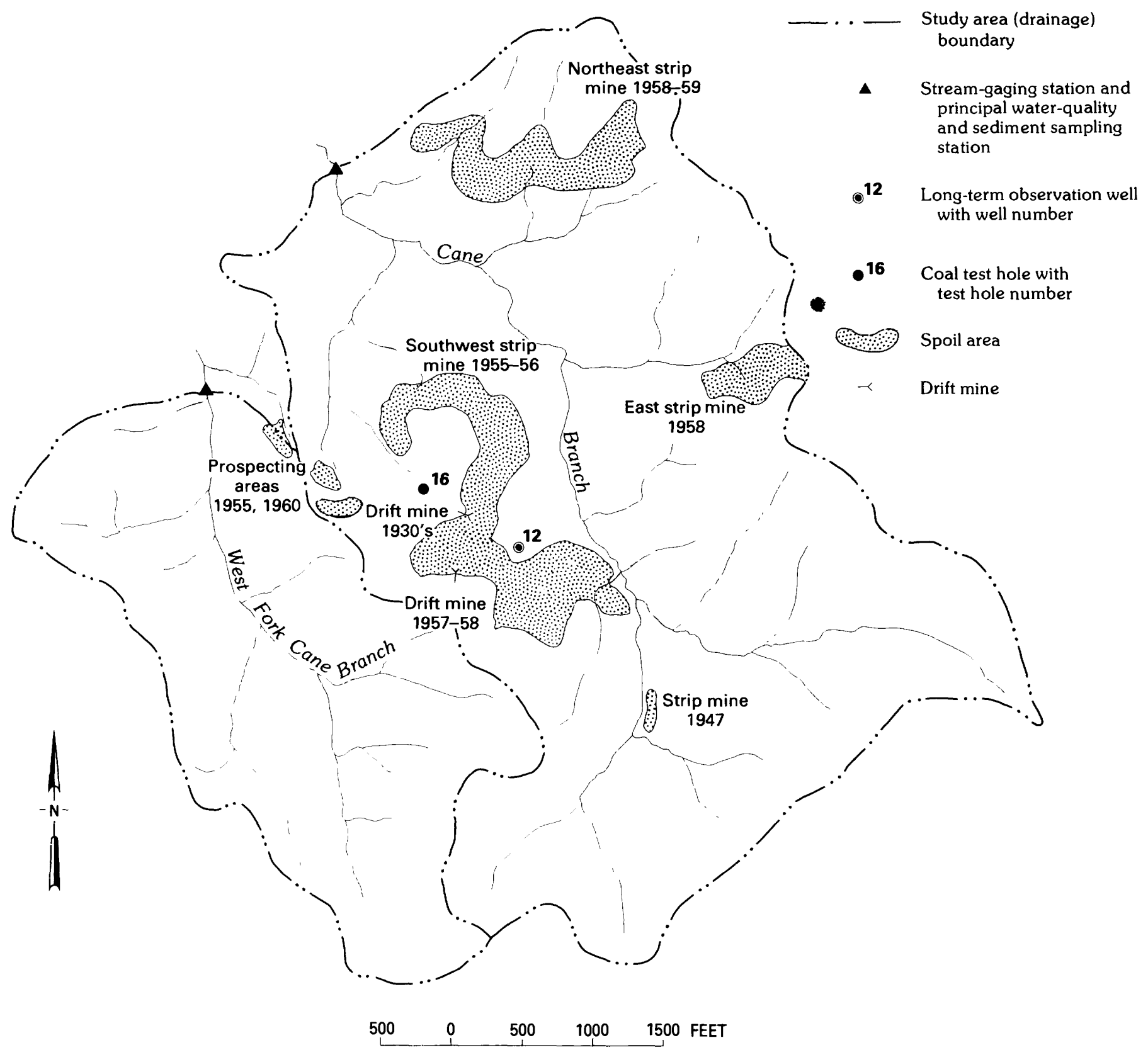

Figure 2.-Location of mines and prospect areas in the Cane Branch and West Fork Cane Branch study areas, $1973-74$.

daily recording of water discharge at that station was resumed and continued from May 1973 to September 1974. The daily record for Helton Branch, the West Fork Cane Branch crest-stage partial-record station, and the four recording rain gages in the Cane and Helton Branch basins had continued in operation since the end of the 1955-66 phase of the project. The location of these data-collection points is shown in figure 1.

\section{DATA AVAILABLE}

Daily precipitation records were available for two stations in each of the two basins in the study area. In addition, daily records were available at three nearby U.S. Weather Service stations, namely, Cumberland Falls, Monticello, and Stearns, for evaluation of the four gages in the study area. 
The precipitation records for the gages, gages 5 and 6 in Helton Branch basin and gages 1 and 2 in Cane Branch basin, were reviewed and evaluated for accuracy using U.S. Weather Service station data at Cumberland Falls, Monticello, and Stearns for comparison. Double-mass curves were used extensively in the evaluation. The two gages in Cane Branch basin were found to yield valid, acceptable data. However, the gages in Helton Branch basin (gages 5 and 6) were found to give consistently low readings beginning in 1965 , probably owing to the rain-shadow effect of encroaching trees and shrubs. In addition, gage 5 developed an instrument error. From the double-mass curve evaluation, the record for gage 6 was corrected for the period 1965-74 on the basis of the records for gages 1 and 2 in Cane Branch basin and the U.S. Weather Bureau gages at Cumberland Falls, Monticello, and Stearns. From 1965 on, the record for gage 5 was not used. Annual precipitation records, including the corrected record for gage 6, runoff, changes in groundwater storage, and evapotranspiration, are given in table 1.

Maximum precipitation amounts recorded in Cane Branch basin since the 1966 water year are listed in table 36 (at end of paper). Listed are storms during which precipitation exceeded 2 inches at one of the two recording precipitation stations.

Records of daily mean flow at the gaging stations, Cane Branch near Parkers Lake and Helton Branch at Greenwood, have been published by the U.S. Geological Survey in its Water-Supply Paper annual series
(1957-60), in the Water-Supply Paper 5-year series (1961-65 and 1966-70), and in the series of annual State reports (1961-74). The water-discharge records for the Cane Branch and Helton Branch stations are rated as fair to poor for the purpose of evaluating the effects of strip mining on runoff.

Monthly values of runoff for Cane Branch for the 1973 and 1974 water years are given in table 30 , and monthly values of runoff for Helton Branch for the water years 1967-74 are given in table 31 (Both tables at end of paper).

Comparable flow and precipitation data prior to the 1967 water year were given by Thomas (in Collier and others, 1964, B5-B6) and by McCabe (in Collier and others, 1970, p. C62-C65).

\section{RUNOFF CHARACTERISTICS}

The distributon of average monthly runoff in the Cane Branch and Helton Branch basins for the periods February 1956 to September 1966 and October 1973 to September 1974 is shown in figure 3. A comparison of the runoff characteristics for 1956-66 indicates that the monthly distributon of flow is about the same for both basins.

The 1974 water year was a very wet one. The runoff from the Cane Branch basin during the 1974 water year was 31.35 inches, and from the Helton Branch basin, 36.49 inches (table 1). These amounts were by far the maximum annual runoff from each basin for the period of record. In relation to total precipitation for

TABLE 1.-Summary of annual precipitation, runoff, change in ground-water storage contributing to base flow, and evapotranspiration [All values are in inches]

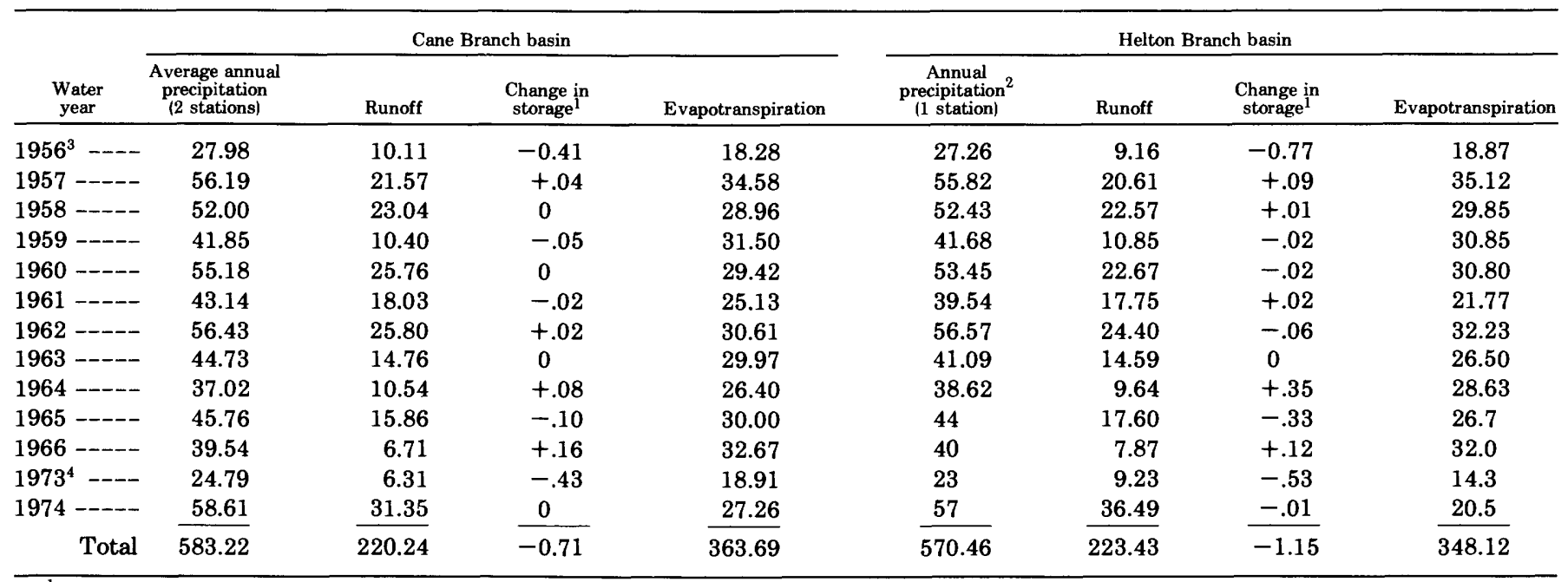

\footnotetext{
${ }^{1}$ Change in ground-water storage contributing to base flow.

${ }^{2}$ Record for gage 6: 1956-64 as measured; 1965-74 corrected by double-mass curve technique using gages 1 and 2 versus U.S. Weather Service stations at Cumberland Falls, Monticello, and Stearns and gages 1 and 2 versus gage 6.

${ }^{3}$ March to September

${ }^{4}$ May to September.
} 


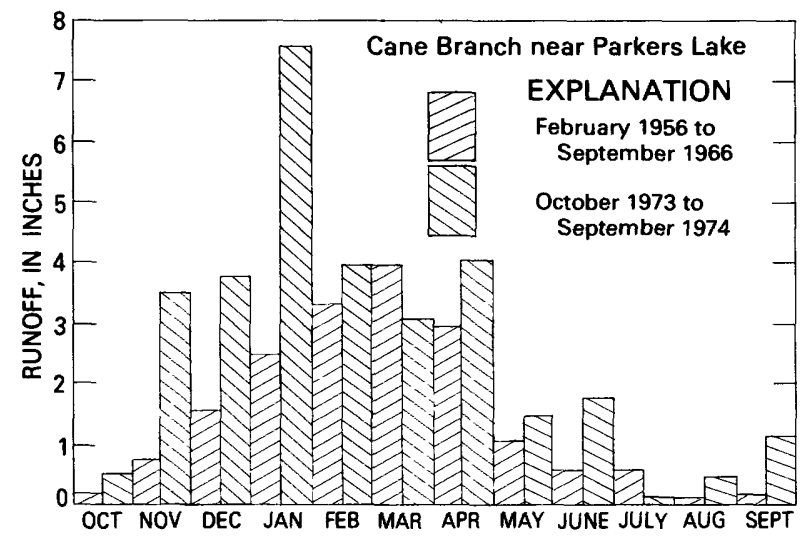

A. Cane Branch basin

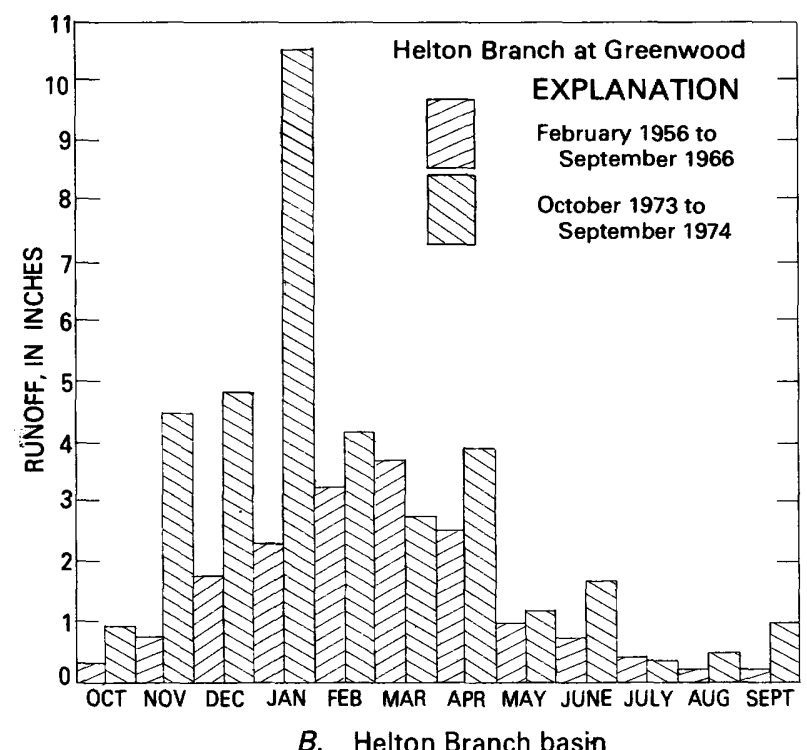

FiguRE 3.-Comparison of monthly runoff for the periods of record, $A$ : Cane Branch basin and $B$, Helton Branch basin.

1974 in the basins, runoff was 53.5 percent for Cane Branch and 64 percent for Helton Branch. These values are much greater than the average runoff for the 19-year period of record, 1956-74, of 38 percent for Cane Branch and 39 percent for Helton Branch.

Expressed in these terms, the extent of wetness in the two basins in 1974 was about 15 percent greater than the 19-year average of runoff to total precipitation for Cane Branch basin and about 25 percent greater for Helton Branch basin.

The data show (fig. 3) that high runoff in the 1974 water year occurred during November, December, and January, when excessive rains fell on the basins and produced runoff more than twice as great, on the whole, as the average runoff for these months. The previous annual maximum runoff from the Cane Branch basin for the water years 1957 to 1966 was 25.80 inches for the 1962 water year (table 1). The previous annual maximum runoff from the Helton Branch basin for the 1957 to 1973 water years was 27.04 inches for the 1973 water year, which makes it probable that runoff in 1973 in Cane Branch was also the second highest of record.

For the 12 years of record, 1956-66 and 1974, the average annual runoff from Cane Branch basin was 16.9 inches, and for the 19 years of record for Helton Branch basin, 1956-74, average annual runoff was 17.2 inches. Some monthly records for Cane Branch basin for the 1956 and 1973 water years were missing. Excluding those 2 years, the average annual runoff for the 11 years of continuous record for Cane Branch basin was 18.5 inches and for Helton Branch, 19.5 inches. For all practical purposes, average annual runoff amounts for the periods of record for the two basins were within an inch of each other. McCabe (in Collier and others, 1970) also correlated runoff from Cane Branch with runoff from Helton Branch at the two stations for different periods of the year (annual 7-day minimum and 30-day minimum flows) for the period of record. He concluded that the relation in runoff between the two basins changed very little during the 17-year period.

Thus, it can be shown that in the exceptionally wet water year of 1974, the annual runoff in both basins was almost twice the annual average for the period of record.

This similarity between runoff of the two basins for the periods of record is evidence that mining has produced no noticeable changes in average monthly and annual runoff of the Cane Branch basin. The results of more detailed comparisons of the basins using other runoff characteristics are discussed in the following sections.

\section{FLOW DURATION AND VARIABILITY}

A comparison of variability in runoff of Cane and Helton Branches for the periods 1956-66 and 1973-74 is shown in figure 4 by flow-duraton curves. These curves are cumulative-frequency curves that show the percentage of time during which specific discharges were equaled or exceeded, without regard to sequence of flow.

Runoff characteristics at Cane and Helton Branches were different during May 1973-September 1974 than during 1956-66. During the earlier period, the discharge per square mile at Helton Branch exceeded that for Cane Branch at the lower flows. During storms, Cane Branch had the higher flow per unit area. This is shown in figure 4 by the lesser slope of the duration curve for Helton Branch at low discharges and indicates a somewhat greater seepage of ground water into Helton Branch to sustain the stream during 


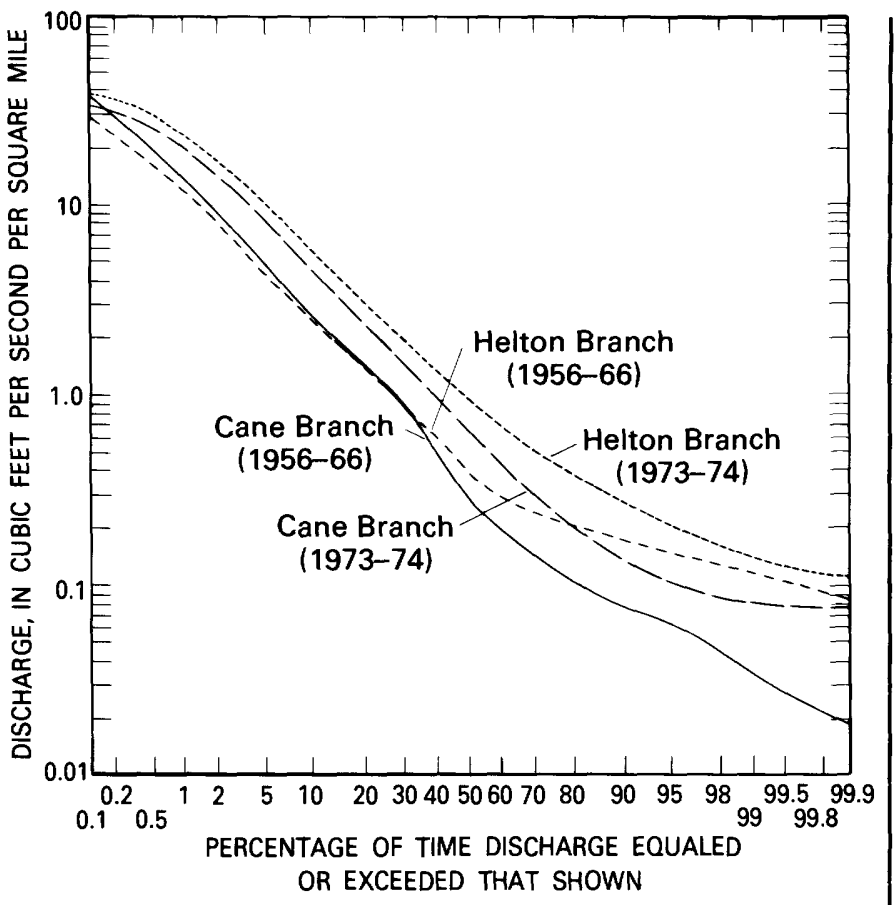

Figure 4.-Flow-duration curves, Cane and Helton Branches.

periods of dry weather. However, a duration curve for 1 year of record is not as reliable as a curve based on several years of record.

At duration of 50 percent, daily flow at Helton Branch during the period 1956-66 was approximately $1 \frac{1}{2}$ times greater than at Cane Branch (Thomas, in Collier and others, 1964). At 84-percent duration (one standard deviation from the median), Helton Branch had nearly three times the flow of Cane Branch.

Cane Branch had greater flood discharges than Helton Branch. At durations of less than about 20 percent, which represent overland flow, Cane Branch discharges exceeded those of Helton Branch by as much as 60 percent (Thomas, in Collier and others, 1974). This situation was reversed during 1973-74, when runoff was greater than during previous water years of record. Helton Branch generally exceeded Cane Branch throughout the range of discharge. At durations of less than about 20 percent, Helton Branch flood flows exceeded those of Cane Branch by as much as 30 percent.

The general long-term situation at higher base flows and lower flood discharges in Helton Branch can be attributed in part to better infiltration rates and greater storage capacity of the rocks due to both a thick duff layer on the forest floor and much more sandstone in the basin. Cane Branch basin has much less duff and sandstone, and both those conditions favor lower base flows and higher flood discharges. It should be noted that the discharge data are rated as fair to poor owing to instrument and measurement problems.
In summary, there is no hard and satisfactory explanation for some of the water-discharge data. Factors such as climate, channel geometry, and the relation between area and elevation are considered to have minor effects on the differences in flow-duration characteristics of the two basins.

\section{PEAK DISGHARGES}

The annual maximum discharges for Cane Branch and Helton Branch were analyzed by the annual flood method developed by Dalrymple, as described by McCabe in Collier and others $(1970$, p. C6-C7). The recurrence interval for each flood at each of the stations was plotted against the discharge of the flood in cubic feet per second per square mile (see tables 32-34 at end of paper), and smooth curves were fitted by eye to the plots for each of the stations (fig. 5).

The curves in figure 5 might be in error for the rarer events, but their relative positions are not expected to change greatly for longer periods of record. The addition of flood peaks for the water years 1967-74 changed the curves somewhat but did not change the relative positions of the three curves. The curves show that Cane Branch has a greater flood potential than Helton Branch.

The list of flood peaks makes up a partial duration series and covers a period of nearly 19 years ending September 1974. Most of the floods were associated with "winter-type" storms, that is, storms generally of longer duration during which precipitaton intensities were not particularly high. In contrast, "summertype" storms, usually typified by one or more bursts of rainfall of high intensity, produced lesser peak flows (Thomas, in Collier and others, 1964, p. B9). Significant increases in Helton Branch discharges are mainly associated with winter-type storms. Antecedent hydrologic conditions and vegetative characteristics generally favor higher runoff in winter, also.

For summer storms, the lower peak discharges and small runoff show that retention characteristics, in-

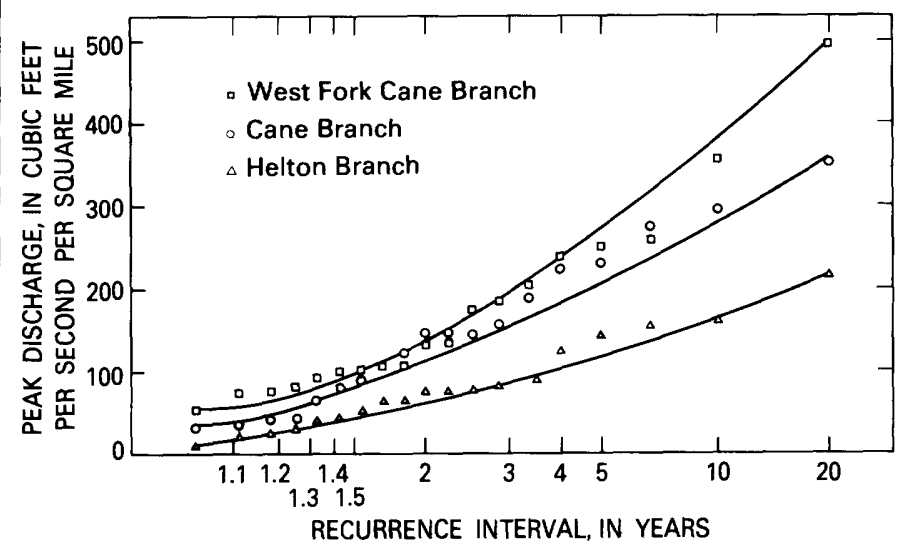

FigURE 5.-Frequency of annual floods, water years 1956-74. 
cluding the impediment of overland and subsurface runoff and loss by evaporation and transpiration, are important factors in both basins during the summer.

Time intervals from the beginning of flood rises to the peaks of the floods were determined by Thomas for the Cane and Helton Branches for 1958-59. He found that the lag at Cane Branch was about 1 hour $10 \mathrm{~min}$ utes less than at Helton Branch. McCabe (in Collier and others, 1970) reported that the additional years of record since the 1959 water year had not changed this average difference. "Thus, it appears that the 1959 mining in the northeastern part of the Cane Branch basin had no measurable effect on the rate at which flood peaks moved downstream" (Collier and others, 1970, p. C7).

\section{MONTHLY RUNOFF}

A correlation of monthly runoffs for Cane Branch and Helton Branch during the periods 1958-66 and 1973-74 is shown by the solid regression line in figure 6 . The dashed line in figure 6 is the equal yield line. Points plotted below the equal yield line represent runoff per square mile of Helton Branch that exceeded Cane Branch, and points plotted above the line, when runoff of Cane Branch exceeded that of Helton Branch. As described in the "Runoff Characteristics" section (also see fig. 3), runoff in Helton Branch generally exceeded that in Cane Branch during the 1973-74 period and at times of low flow or during rainless periods.

For 1958-66, at discharges greater than $1\left(\mathrm{ft}^{3} / \mathrm{s} / \mathrm{mi}^{2}\right.$, the runoff of Cane Branch was slightly more than that of Helton Branch. The points for months of low runoff are scattered but indicate less runoff in Cane Branch than in Helton Branch. Thus, the greater runoff in Helton Branch for both low and high runoff during 1974 may reflect, for years of heavy precipitation, the inherent difference in flow that existed before strip mining began.

\section{ANNUAL SUMMARIES OF PRECIPITATION AND RUNOFF}

Annual summaries of precipitation, runoff, changes in base-flow storage, and computed evapotranspiration for Cane Branch and Helton Branch for years for which there are runoff records for Cane Branch are given in table 1. Annual values for 1973 and 1974 runoff were taken from tables 30 and 31 . Table 1 is an update of table 1 in Collier and others (1970). Annual values of 1973 and 1974 precipitation for Cane Branch were taken from table 35 . Commencing about 1961, the precipitation gages for Helton Branch apparently were in some kind of rain shadow, for records were not consistent with precipitation records for Cane Branch and for nearby U.S. Weather Service stations. Therefore, the annual precipitation amounts for Helton Branch are values corrected using double-mass curves, as indi- cated, and represent revisions of the data given in table 1 of Collier and others (1970).

Changes in base-flow storage were chosen from figure 10 in Collier and others (1964) using the daily discharge on the last day of the indicated water year. Thomas developed the relation between base-flow discharge and storage on the basis of records for January 1956 to September 1958. Additional records collected for water years 1959-66 showed no change in the relation. The change in storage for each water year is minor, as the water year ends September 30, during the low-water season.

\section{CONCLUSIONS}

Analysis of precipitation and runoff data for the periods of records, including monthly runoff, flow duration and variability, and peak discharges, provides evidence that there have been no significant changes in runoff characteristics that could be related to the history of mining in the area.

For all practical purposes, the average annual runoff amounts for the period of record for Cane Branch and the unmined Helton Branch were within an inch of each other, about 19 inches for the 19-year period of record 1956-74. That portion of precipitaton that runs off also is nearly identical, 39 to 38 percent for each basin. The monthly distribution of flow is about the same for both basins.

In the 1974 water year, heavy rainfall on the basins produced runoff from November to January that was more than twice as great as the average runoff for these months. Runoff was about 54 percent of precipitation for Cane Branch basin and 64 percent of precipitation for Helton Branch basin.

Previous analysis of precipitation and runoff for Cane Branch and Helton Branch basins for the water years 1955-66 indicated that measurable differences in runoff characteristics between the two basins may be attributed more to differences in geology, soils, and vegetative cover than to mining operations (see Collier and others, 1970 , p. C9). This previous analysis indicated that at higher discharges Cane Branch has greater flows on a square-mile basis than Helton Branch and that Helton Branch has greater base flows on a square-mile basis than Cane Branch.

During the excessively wet 1974 water year, the runoff in inches from Helton Branch was double the long-term average and exceeded the runoff from Cane Branch by 5.14 inches.

\section{GROUND WATER \\ By Robert W. Davis \\ U.S. Geological Survey}

Investigation of the ground water in the principal spoil bank (fig. 2, southwest strip mine) mined in 


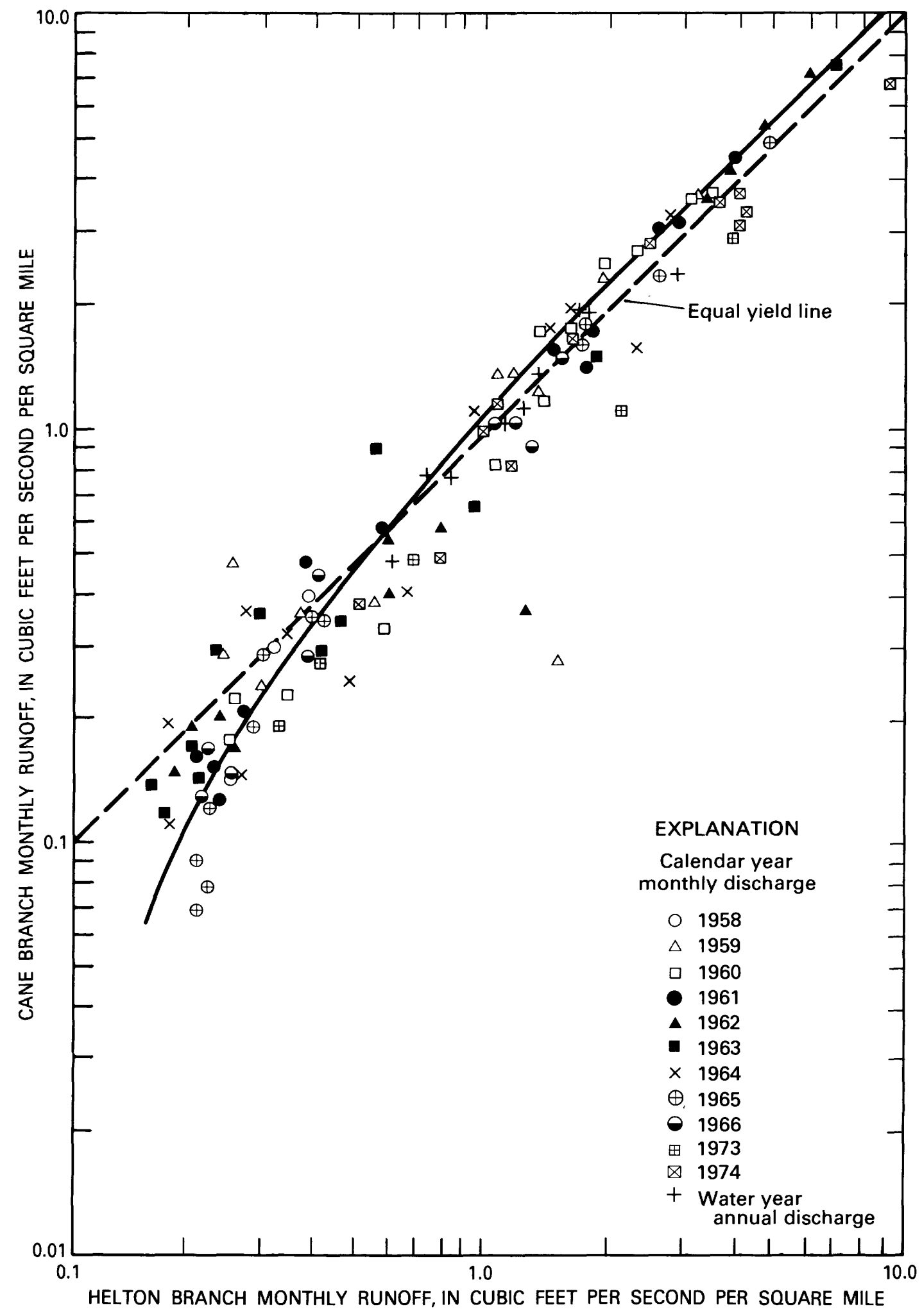

Figure 6.-Correlation of monthly runoffs, Cane and Helton Branches, October 1958 to September 1966 and May 1973 to September 1974.

1955-56, and the adjacent bedrock ridge was begun in 1958 to determine the effects of mining on the occurrence and quality of ground water in the Cape Branch study area. The ridge is the source of the coal and spoil material, and it is connected hydrologically to the spoil bank. The unmined West Fork Cane Branch study area 
on the other side of the same ridge provided a basis for comparison of the ground-water characteristics of mined and undisturbed land.

Price (in Collier and others, 1964, p. B19-B24) concluded that the quantity of water discharged from the approximately 1.3 linear miles of spoil banks as determined by using calculations based on Darcy's law is very much smaller than the quantity determined on the basis of seasonal changes in storage. A rough estimate of the quantity of water discharged from the spoil banks ranges from approximately $40 \mathrm{gal} / \mathrm{d}$ if the spoil banks are of lower permeability to approximately $600 \mathrm{gal} / \mathrm{d}$ if the spoil banks are of higher permeability. Price further concluded that the value of $10,000 \mathrm{gal} / \mathrm{d}$, obtained by the changes-in-storage method, is the more accurate because it is based on a longer period of time and a larger area. The wide difference in discharge obtained by the two methods may indicate relatively rapid ground-water movement along zones of higher permeability within or beneath the spoil piles. Even so, the total amount of water moving in and out of the banks is small. Probably some of the water seeps into the bedrock and streams, but most of it is discharged by evaporation.

Hopkins and Mull (in Collier and others, 1970, p. C9-C14) stated that in spite of the small transmissivity of the spoil, water seeping from the spoil bank continuously provides highly mineralized water to Cane Branch. This contribution is particularly significant during periods of low flow, when it constitutes a major part of the flow of Cane Branch and provides the bulk of the dissolved-solids and acid loads of that stream.

The investigators concluded there had been no significant change in the occurrence and movement of ground water in the vicinity of the southwest spoil bank since observations began in the spring of 1958. Shallow ground water in bedrock is recharged by precipitation and moves from topographically high areas to streams. Ground water in the southwest spoil bank is recharged by direct infiltration of precipitation and seepage from adjacent pools, and it discharges mostly eastward into tributaries draining the spoil bank area.

Fluctuations of the water table in the spoil bank are largely controlled by direct infiltration of precipitation during the winter-spring season, but they are strongly influenced by seepage from pools adjacent to the spoil bank during the summer-autumn season. Recharge from the pools varies with water levels in the pools during the summer-autumn season, but it is fairly constant during the winter-spring season, when the pools are full most of the time.

The shape and slope of the water table in the spoil bank have not changed significantly since observations began in 1958 (see fig. 8 in Collier and others, $1970,(12))$. Although the amount of ground water in storage in bedrock areas and in the southwest spoil bank changes seasonally, there was little overall change over the period of record. However, there was indication of a small overall loss in storage during the study period, mostly the result of deficient precipitation in 1963, 1964, and 1966 but possibly due in part to deepening of gullies in the spoil bank and increased transpiration by vegetation.

Erosion of the spoil piles, vandalism, and filling of wells by debris have destroyed or partly filled most of the former network of temporary observation wells at the project site. However, well 12 (see fig. 2), which predates the beginning of the project, was preserved for observation of changes in both water level and water quality. No upward or downward trend in water level was noted, merely seasonal variations in response to rainfall and evapotranspiration.

During the period 1966-74, water samples were collected from well 12 each year except 1972. the analyses of water from this well are shown in table 2. Musser and Pickering (in Collier and others, 1970, p. C19) observed that between 1959 and 1966 there was an increase in mineralization of the water from well 12 . The increase in mineralization was relatively minor, however, and was apparent only in the sulfate content of the well water. Since 1966, the amount of mineralization of the water has varied, but it is within the range of the 1959-66 analyses, generally above the median level for that period. The quality of water from the well is neither better nor worse.

There is no discernible correlation between sulfate and annual precipitation during the water years 1959-66 and 1973-74 (fig. 7). Musser and Pickering (in Collier and others, 1970, p. C19) found a pattern of relation between monthly precipitation and specific conductance. They observed that the ground water in coal-test hole 16 was most dilute (least mineralized and had lowest conductance) during the winter-spring period, when recharge is greatest, and most mineralized during the summer-autumn period, when recharge is slight and evapotranspiration is high.

\section{GEOCHEMISTRY OF WATER \\ By Robert W. Davis \\ U.S. Geological Survey}

\section{INTRODUCTION}

One of the most significant and obvious effects of strip mining in Cane Branch basin on the environment is the degradation of the chemical quality of water in Cane Branch. The stream became highly mineralized and acidic in early 1956 because of strip mining in the basin beginning in 1955. Mining was intermittent, last occurring in 1959, but Cane Branch in 1974 remained mineralized and acidic. This section of the report 
TABLE 2.-Chemical analyses of common constituents in [All constituents in milligrams

\begin{tabular}{|c|c|c|c|c|c|c|c|c|}
\hline & Date of sample & $\begin{array}{c}\text { Dissolved } \\
\text { silica } \\
(\mathrm{SiO}) \\
(\mu \mathrm{g} / \mathrm{L})\end{array}$ & $\begin{array}{c}\text { Dissolved } \\
\text { iron } \\
(\mathrm{Fe}) \\
(\mu \mathrm{g} / \mathrm{L})\end{array}$ & $\begin{array}{c}\text { Dissolved } \\
\text { manganese } \\
(\mathrm{Mn}) \\
(\mu \mathrm{g} / \mathrm{L})\end{array}$ & $\begin{array}{l}\text { Dissolved } \\
\text { calcium } \\
\text { (Ca) }\end{array}$ & $\begin{array}{c}\text { Dissolved } \\
\text { magnesium } \\
\text { (Mg) }\end{array}$ & $\begin{array}{l}\text { Dissolved } \\
\text { sodium } \\
\text { (Na) }\end{array}$ & $\begin{array}{l}\text { Dissolved } \\
\text { potassium } \\
\text { (K) }\end{array}$ \\
\hline Oct. & 31,1968 & 43 & $\ldots$ & --- & 28 & 13 & 31 & 3.4 \\
\hline Sept. & 26,1969 & 32 & --- & --- & 24 & 11 & 29 & 3.2 \\
\hline Nov. & 4,1970 & 19 & $-\cdots$ & --- & 20 & 7.6 & 12 & 3.3 \\
\hline Oct. & 28,1971 & 38 & -- & --- & 25 & 11 & 30 & 3.4 \\
\hline
\end{tabular}
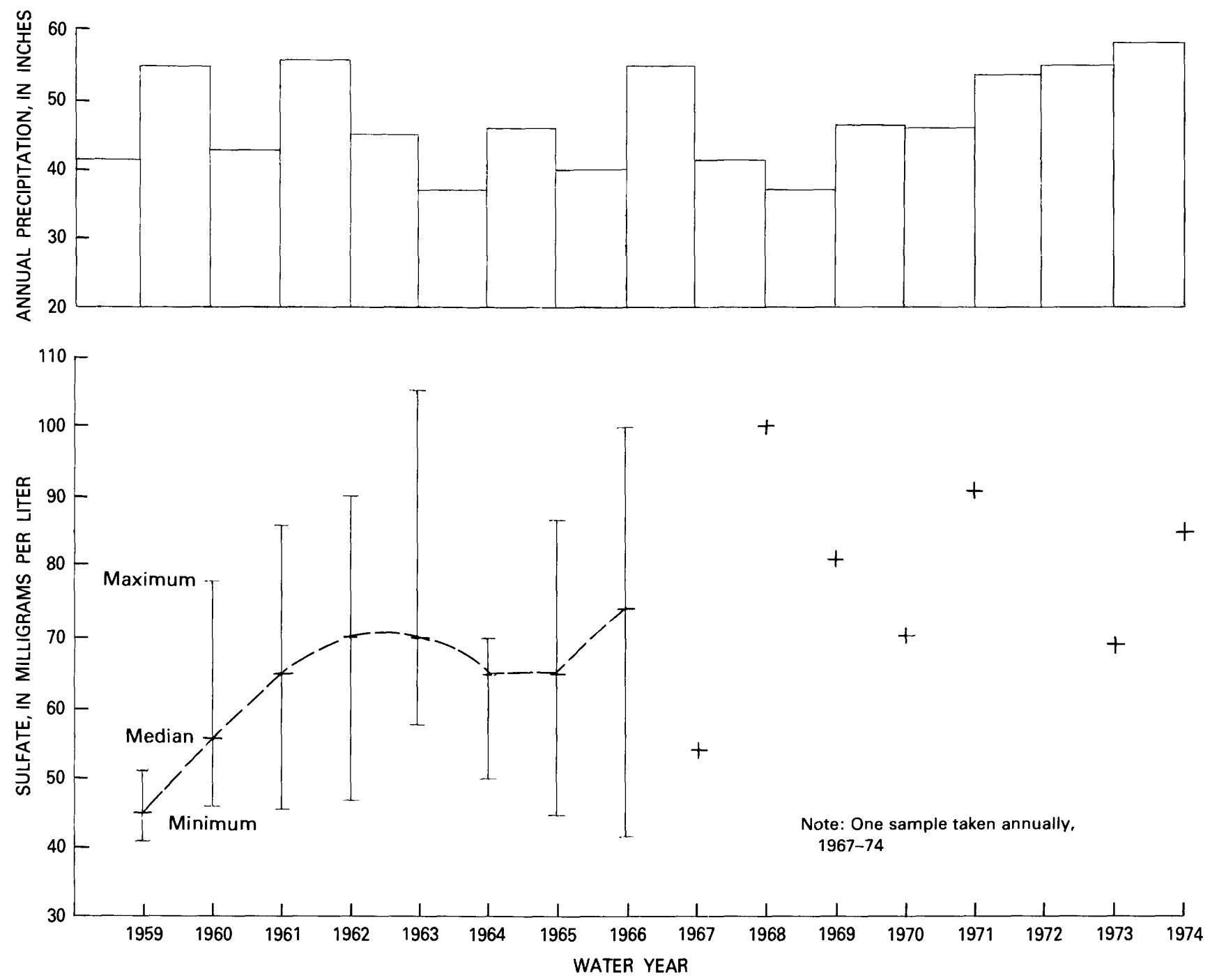

FiguRe 7.-Changes in sulfate concentration of water in well 12 and annual precipitation, 1959-66 and 1973-74.

reviews and describes the changes in the chemical quality of water within the Cane Branch study area affected by strip mining and describes the chemical quality of water in Helton Branch, a nearby, com- parable basin in which no strip mining has occurred. Results of two earlier studies of these areas have been published in Collier and others (1964, p. B25-B48) and Collier and others (1970, p. C14-C30). 
samples of ground water from well 12, 1967-71 and 1973-74

per liter except as noted]

\begin{tabular}{|c|c|c|c|c|c|c|c|c|}
\hline $\begin{array}{c}\text { Bicarbonate } \\
\left(\mathrm{HCO}_{3}\right)^{\prime}\end{array}$ & $\begin{array}{c}\text { Dissolved } \\
\text { sulfate } \\
\left(\mathrm{SO}_{4}\right)\end{array}$ & $\begin{array}{c}\text { Dissolved } \\
\text { chloride } \\
\text { Cl) }\end{array}$ & $\begin{array}{l}\text { Dissolved } \\
\text { fluoride } \\
\text { (F) }\end{array}$ & $\begin{array}{c}\text { Dissolved } \\
\text { nitrate } \\
\left(\mathrm{NO}_{3}\right)\end{array}$ & $\begin{array}{c}\text { Dissolved } \\
\text { solids } \\
\text { (residue } \\
\text { at } 180^{\circ} \mathrm{C} \text { ) }\end{array}$ & $\begin{array}{l}\text { Hardness } \\
\text { (Ca, Mg) }\end{array}$ & $\begin{array}{c}\text { Specific } \\
\text { conductance } \\
(\mu \mathrm{mho})\end{array}$ & $\mathbf{p H}$ \\
\hline 6 & 54 & 62 & 0.5 & 43 & 268 & 99 & 426 & 5.1 \\
\hline 6 & 81 & 51 & .5 & 31 & 266 & 105 & 434 & 4.9 \\
\hline 3 & 70 & 22 & .4 & 18 & 172 & 81 & 278 & 5.0 \\
\hline 4 & 91 & 51 & .8 & 34 & 288 & 110 & 442 & 4.7 \\
\hline
\end{tabular}

The scope of this study of the geochemistry of the water in 1973-74 is more limited than that of the previous two studies; however, the 19-year record of periodic water sampling at the gaging station on Cane Branch furnishes a unique opportunity to compare the water-quality changes while mining was active with the changes after mining ceased. Continuous recording of streamflow and measurements of conductivity of water at the Cane Branch gaging station were discontinued from 1966 to 1973; therefore, no attempt was made to calculate cumulative dissolved-solids loads and chemical-erosion values to compare the mined with the unmined basin. However, the results from water year 1974 records are included in this section, as is a discussion of quantitative comparisons of chemical loads transported prior to 1966 and in water year 1974 by Cane Branch and Helton Branch and chemical losses from the land areas of the two basins.

\section{HELTON BRANCH}

Dissolved solids in water in Helton Branch during 1973-74 remained at low levels, never exceeding $60 \mathrm{mg} / \mathrm{L}$ in the monthly chemical analyses. These results are comparable to similar low levels observed in earlier studies. The water in Helton Branch is a dilute calcium bicarbonate type (see table 3). In spite of the differences in sampling patterns between the 1958-65 period and the 1973-74 period, the quality of water in Helton Branch was substantially the same. Based on median values of 14 samples for 1958-65 and 13 samples for 1973-74, the following values, in milligrams per liter, are obtained:

$\begin{array}{lcc} & 1958-65 & 1973-74 \\ \text { Dissolved solids ---- } & 25 & 32 \\ \text { Silica --_----- } & 6 & 5.8 \\ \text { Calcium -------- } & -10 & 5 \\ \text { Bicarbonate ------ } & 10 & 14 \\ \text { Sulfate ------ } & 5.3 & 7.4\end{array}$

Very small but detectable amounts of minor elements also occur in the water of Helton Branch, as given in table 4. There appears to be no occurrence of these metals in water in amounts exceeding drinking water standards.
The range of $\mathrm{pH}, 6.6$ to 7.4 units, of Helton Branch water during 1973-74, as shown in figure 8, was slightly less than for 1958-65 (pH 5.8 to 7.4 units), as reported by Musser and Pickering (in Collier and others, 1970 , p. C15). Median pH was about 7.2 units, compared with about 6.7 units during the sampling period 1956-59 (fig. 8). One cause of this slightly higher alkalinity, as shown by the bicarbonate content, is considered to be the effects of the highway relocation and the addition of limestone fill in the headwaters of the
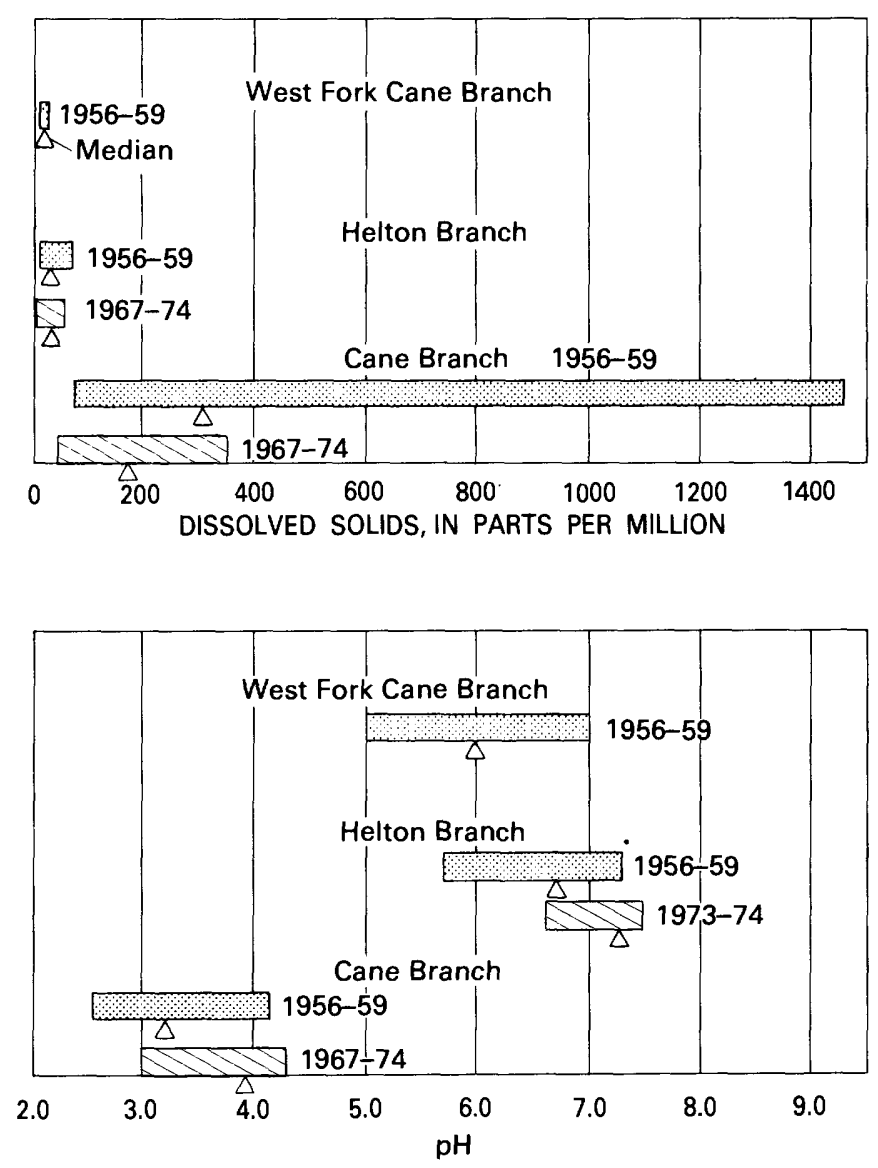

FIGURE 8.- Range of dissolved solids and $\mathrm{pH}$ of surface waters in study areas, June 1956 to December 1959 and August 1967 to October 1974. 
TABLE 3.-Chemical analyses of common constituents in [All constituents in milligrams

\begin{tabular}{|c|c|c|c|c|c|c|c|c|}
\hline & Date of sample & $\begin{array}{c}\text { Instantaneous } \\
\text { discharge } \\
\left(\mathrm{ft}^{3} / \mathrm{s}\right)\end{array}$ & $\begin{array}{l}\text { Dissolved } \\
\text { silica } \\
\left(\mathrm{SiO}_{2}\right)\end{array}$ & $\begin{array}{c}\text { Dissolved } \\
\text { aluminum } \\
(\mathrm{A})) \\
(\mu \mathrm{g} / \mathrm{L})\end{array}$ & $\begin{array}{c}\text { Dissolved } \\
\text { iron } \\
(\mathrm{Fe}) \\
(\mu \mathrm{g} / \mathrm{L})\end{array}$ & $\begin{array}{c}\text { Dissolved } \\
\text { manganese } \\
(\mathrm{Mn}) \\
(\mu \mathrm{g} / \mathrm{L}\end{array}$ & $\begin{array}{c}\text { Dissolved } \\
\text { calcium } \\
\text { (Ca) }\end{array}$ & $\begin{array}{c}\text { Dissolved } \\
\text { magnesium } \\
\text { (Mg) }\end{array}$ \\
\hline & 1973 & & & & & & & \\
\hline Sept. & $11-\infty-1$ & 0.43 & 7.8 & -- & 120 & 26 & 13 & 1.3 \\
\hline Nov. & $14-\cdots$ & .31 & 5.8 & 30 & 50 & 14 & 5.4 & 1.2 \\
\hline \multirow[t]{2}{*}{ Dec. } & 26 & 12.5 & 4.4 & -- & 30 & 40 & 3.5 & 1.5 \\
\hline & 1974 & & & & & & & \\
\hline Feb. & $5-\ldots$ & 13.4 & 4.8 & -- & -- & -- & 4.3 & 1.0 \\
\hline Mar. & $8 \ldots$ & 1.9 & 5.0 & -- & 70 & 25 & 4.1 & .9 \\
\hline Apr. & $25-\cdots---$ & 1.3 & 5.2 & -- & 10 & 50 & 4.2 & 1.0 \\
\hline May & $2-$ & 1.4 & 4.7 & -- & -- & - & 7.0 & 1.4 \\
\hline June & $7--$ & .96 & 5.8 & -- & 30 & 33 & 5.0 & .9 \\
\hline July & $23 \ldots$ & .26 & 6.5 & -- & 90 & 15 & 2.3 & .4 \\
\hline Aug. & 12 & .31 & 5.8 & - & 9 & 25 & 7.0 & .8 \\
\hline Sept. & 17 - & .70 & 6.4 & - & 80 & 30 & 9.0 & 1.2 \\
\hline Sept. & 30 & .26 & 6.5 & -- & 30 & 10 & 5.9 & 1.0 \\
\hline Oct. & $29-\ldots$ & .18 & 6.5 & -- & 70 & 30 & 3.8 & .8 \\
\hline
\end{tabular}

${ }^{1}$ Daily mean.

TABLE 4.-Chemical analyses of total and dissolved minor elements (All constituents in

\begin{tabular}{|c|c|c|c|c|c|c|c|c|}
\hline & Date of sample & $\begin{array}{c}\text { Dissolved } \\
\text { arsenic } \\
\text { (As) }\end{array}$ & $\begin{array}{l}\text { Total } \\
\text { arsenic } \\
\text { (As) }\end{array}$ & $\begin{array}{l}\text { Dissolved } \\
\text { cadmium } \\
\text { (Cd) }\end{array}$ & $\begin{array}{c}\text { Total } \\
\text { cadmium } \\
\text { (Cd) }\end{array}$ & $\begin{array}{c}\text { Dissolved } \\
\text { chromium } \\
\text { (Cr) }\end{array}$ & $\begin{array}{c}\text { Total } \\
\text { chromium } \\
\text { (Cr) }\end{array}$ & $\begin{array}{c}\text { Dissolved } \\
\text { cobalt } \\
\text { (Co) }\end{array}$ \\
\hline & 1973 & & & & & & & \\
\hline Nov. & 14 & - & -- & 0 & - & 0 & -- & 3 \\
\hline Dec. & $26-\cdots$ & 2 & -- & 3 & 4 & 0 & -- & 0 \\
\hline Apr. & 25 & 0 & 0 & 0 & 1 & 3 & 3 & 6 \\
\hline June & 7 - & 6 & 6 & 2 & 1 & 0 & -- & -- \\
\hline Aug. & $12-$ & 0 & 1 & 1 & 2 & 0 & 40 & 2 \\
\hline Sept. & $30-\cdots$ & 0 & 0 & 1 & 0 & 0 & $<10$ & 0 \\
\hline
\end{tabular}

basin in 1965. The limestone is considered the source of the increased and sustained alkalinity in Helton Branch which has persisted for almost 10 years after the relocation of the highway.

The dissolved-solids concentration of the runoff is virtually constant (fig. 9) and is controlled by chemical equilibrium between the solutes in precipitation and solid phases. In the study area, the dissolved-solids concentration of rainwater ranges from 8 to $10 \mathrm{mg} / \mathrm{L}$ (see Collier and others, 1964, p. B29).

\section{WEST FORK CANE BRANCH}

The single analysis of water in West Fork Cane Branch shows it to be low in concentration of dissolved solids, similar to the water in Helton Branch, and of a dilute magnesium and calcium sulfate and bicarbonate type (tables 5 and 6). The $\mathrm{pH}$ was about midpoint in the range of values reported for 1958-65 (Collier and others, 1970, p. C16). The West Fork Cane Branch basin was prospected but not mined, and water in this stream could be assumed to be very similar to the type of water that would be in Cane Branch if mining had not occurred between 1955 and 1959. The coalprospect trenches dug in 1960 exposed small quantities of iron sulfide minerals to weathering, but there were no significant changes in sulfate or other dissolved solids in the water because of this activity (Collier and others, 1970, p. C16). A few minor elements were barely detectable. The sample collected in 1973-74 shows no appreciable change from previous analyses of water for 1956-61. 
samples from Helton Branch at Greenwood, 1973-74

per liter except as noted]

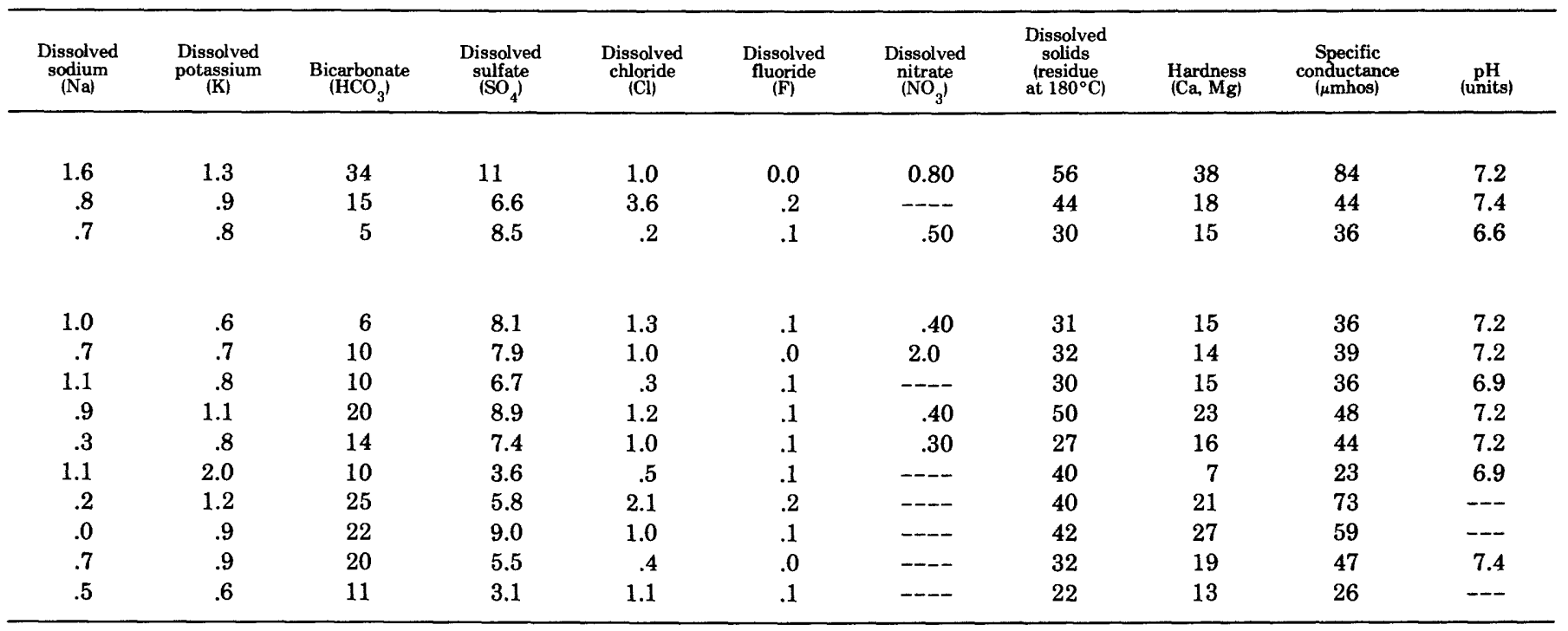

in samples from Helton Branch at Greenwood, 1973-74

micrograms per liter]

\begin{tabular}{|c|c|c|c|c|c|c|c|c|c|c|}
\hline $\begin{array}{c}\text { Total } \\
\text { Cobalt } \\
(\mathbf{C o})\end{array}$ & $\begin{array}{l}\text { Dissolved } \\
\text { Copper } \\
\text { (Cu) }\end{array}$ & $\begin{array}{c}\text { Total } \\
\text { Copper } \\
\text { (Cu) }\end{array}$ & $\begin{array}{l}\text { Dissolved } \\
\text { lead } \\
(\mathrm{Pb})\end{array}$ & $\begin{array}{l}\text { Total } \\
\text { lead } \\
(\mathrm{Pb})\end{array}$ & $\begin{array}{c}\text { Dissolved } \\
\text { mercury } \\
\text { (Hg) }\end{array}$ & $\underset{\substack{\text { Total } \\
\text { mercury } \\
(\mathbf{H g})}}{2}$ & $\begin{array}{c}\text { Dissolved } \\
\text { selenium } \\
\text { (Se) }\end{array}$ & $\begin{array}{c}\text { Total } \\
\text { selenium } \\
\text { (Se) }\end{array}$ & $\begin{array}{c}\text { Dissolved } \\
\text { zinc } \\
(\mathbf{Z n})\end{array}$ & $\begin{array}{l}\text { Total } \\
\text { zinc } \\
(\mathbf{Z n})\end{array}$ \\
\hline- & 0 & - & 8 & -- & .3 & --- & -- & -- & 4 & --- \\
\hline 5 & 10 & 0 & 25 & 33 & .2 & --- & 12 & -- & 4 & 150 \\
\hline 3 & 3 & 5 & 1 & 3 & .1 & .0 & 2 & 6 & 0 & 6 \\
\hline 2 & 0 & 3 & -- & 0 & .0 & .0 & 2 & 2 & 3 & 20 \\
\hline 2 & 2 & 3 & 8 & 12 & .0 & .1 & - & 3 & 10 & 0 \\
\hline 0 & 5 & 3 & 2 & 0 & .0 & .0 & -- & -- & 8 & 4 \\
\hline
\end{tabular}

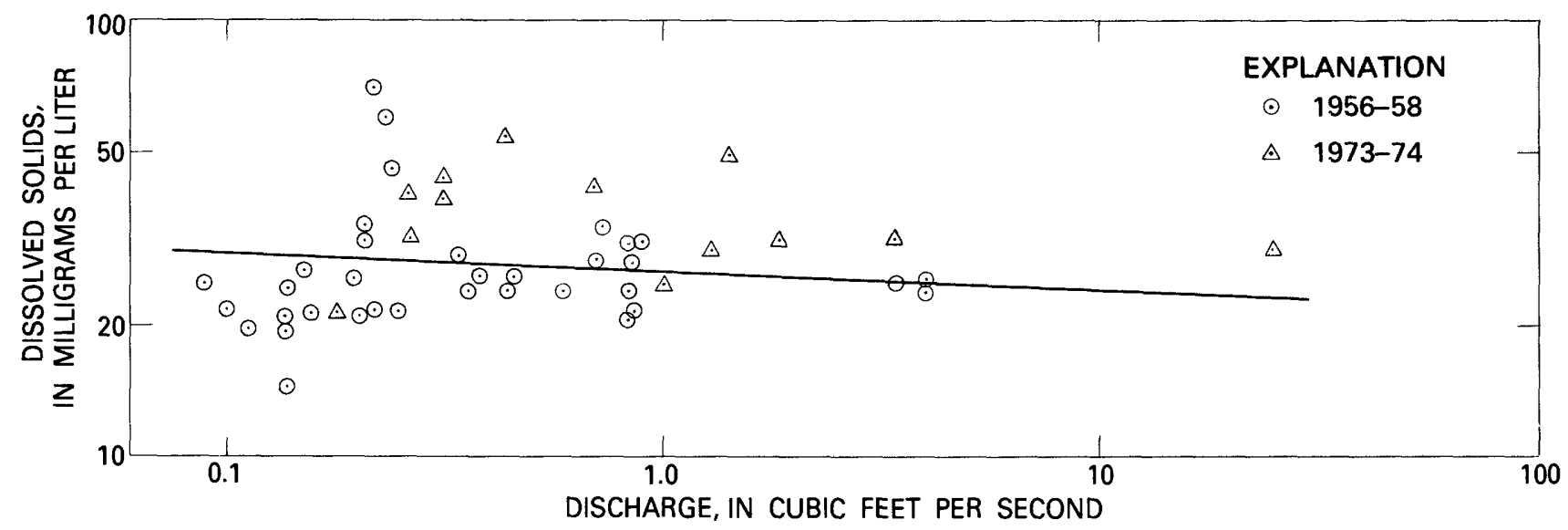

Figure 9.-Relation of dissolved-solids concentration to water discharge in Helton Branch, 1956-58 and 1973-74. 


\begin{tabular}{|c|c|c|c|c|c|c|c|}
\hline $\begin{array}{l}\text { Location and } \\
\text { date of sample }\end{array}$ & $\begin{array}{l}\text { Dissolved } \\
\text { silica } \\
\left(\mathrm{SiO}_{2}\right)\end{array}$ & $\begin{array}{c}\text { Dissolved } \\
\text { aluminum } \\
(\mathrm{Al}) \\
(\mu \mathrm{g} / \mathrm{L})\end{array}$ & $\begin{array}{c}\text { Dissolved } \\
\text { iron } \\
(\mathrm{Fe}) \\
(\mu \mathrm{g} / \mathrm{L})\end{array}$ & $\begin{array}{c}\text { Dissolved } \\
\text { manganese } \\
(\mid \mathrm{Mn}) \\
\langle\mu \mathrm{g} / \mathrm{L})\end{array}$ & $\begin{array}{l}\text { Dissolved } \\
\text { calcium } \\
\text { (Ca) }\end{array}$ & $\begin{array}{l}\text { Dissolved } \\
\text { magnesium } \\
\text { (Mg) }\end{array}$ & $\begin{array}{l}\text { Dissolved } \\
\text { sodium } \\
\text { (Na) }\end{array}$ \\
\hline $\begin{array}{l}\text { West Fork Cane Branch, } \\
\text { Nov. 11, } 1973\end{array}$ & 6.5 & 60 & 130 & 25 & 1.3 & 0.8 & 0.6 \\
\hline
\end{tabular}

\section{CANE BRANCH STUDY AREA}

Strip mining of the Barren Fork coal seam in 1955-56 and 1958-59 exposed and redistributed in the spoil piles large quantities of iron sulfide minerals and nodules (pyrite or marcasite). These minerals are capable of producing acidic water when exposed to weathering processes. Consequently, the water in Cane Branch first became acidic in the spring of 1956 . Precipitation that percolates into the spoil piles and seeps slowly from pools in the mined area into the spoil piles reacts with the buried iron sulfide minerals to produce acidic leachate. Locations of pools are shown in figure 10. This leachate seeps continually from the piles to help sustain the flow of Cane Branch. Overland flow from the spoil piles also dissolved products of weathering and increased the acidity of Cane Branch.

In recent years, erosion has breached some of the formerly permanent pools and they are either dry or contain water only temporarily during storm runoff. The breaching of the pools has reduced somewhat the amount of storage during storms, but the increase in contributing area is considered to be small.

Cane Branch is a slightly mineralized stream (less than 50 micromhos of specific conductance measured on September 11 and 12,1973) upstream from the spoil piles. There is very little buffering capacity in the water because of the low mineralization. Although Cane Branch continues to flow out of the study area as a more mineralized acidic stream, the acid load, as measured by the sulfate ion concentration, is decreasing. The iron sulfide minerals are being dissolved and carried off from both the surface and within the spoil piles. Nodules of pyritic material that once lay on the surface during the early part of the Cane Branch studies have been altered and dissolved by weathering and are no longer visible. Pyritic material remains within the piles, however, causing acidic leachate to drain from the spoil piles into Cane Branch.
POOLS IN MINED AREAS

Pools, most of which contain acidic water, have formed in depressions between the spoil piles and the high wall of the abandoned strip mines. At times in winter and spring, the pools overflow into tributaries of Cane Branch; when the pools do not overflow, their contents are lessened by evapotranspiration and slow seepage into the spoil piles. Chemical analyses of water collected from selected pools (fig. 10) during November $13-15,1973$, are shown in tables 7 and 8 . The samples are considered typical of the water in the pools during the dry period of the year in the fall. Rainfall prior to November $13-15$ was 0.05 inch on November 8,1973 (an insignificant amount) and 1 inch (average of rainfall from four rain gages at the study site) on November $4-5,1973$. On November 14, 1973, the discharge of Cane Branch was $0.31 \mathrm{ft}^{3} / \mathrm{s}$, about at base flow.

Pools 1 through 11 (fig. 10) are in the area on the southwest side of Cane Branch that was strip mined in 1955-56. At the time of sampling, pools 5, 7, and 10 were dry and pool 1 was almost dry. The principal dissolved constituents of the water in the remaining pools were aluminum, iron, manganese, calcium, magnesium, and sulfate. At times, aluminum, iron, and manganese in the acidic waters exceeded $1 \mathrm{mg} / \mathrm{L}$. Bicarbonate was absent in six of the nine water samples. However, there was a marked improvement in the quality of the water over that observed in 1956-59 and 1960-66. For example, in the water years 1956-59, sulfate concentration in these pools ranged from 52 to $3,080 \mathrm{mg} / \mathrm{L}$, with a median value of $530 \mathrm{mg} / \mathrm{L}$. In the 1973 , dry-period sampling, sulfate concentration ranged from about 6 to $200 \mathrm{mg} / \mathrm{L}$, and the median value was $78 \mathrm{mg} / \mathrm{L}$. Further evidence of real change is that sulfate in pools 3,9 , and $11 \mathrm{ex}-$ ceeded $300 \mathrm{mg} / \mathrm{L}$ for all samples in 1956-59 but did not exceed $80 \mathrm{mg} / \mathrm{L}$ in the 1973 samples.

TABLE 6.-Chemical analyses of minor elements in a sample from West Fork Cane Branch near Parkers Lake, 1973 [Results in micrograms per liter]

\begin{tabular}{ccccccc}
\hline $\begin{array}{c}\text { Location } \\
\text { and date } \\
\text { of sample }\end{array}$ & $\begin{array}{c}\text { Dissolved } \\
\text { cadmium } \\
\text { (Cd) }\end{array}$ & $\begin{array}{c}\text { Dissolved } \\
\text { chromium } \\
\text { (Cr) }\end{array}$ & $\begin{array}{c}\text { Dissolved } \\
\text { cobalt } \\
\text { (Co) }\end{array}$ & $\begin{array}{c}\text { Dissolved } \\
\text { copper } \\
\text { (Cu) }\end{array}$ & $\begin{array}{c}\text { Dissolved } \\
\text { lead } \\
\text { (Pb) }\end{array}$ & $\begin{array}{c}\text { Dissolved } \\
\text { mercury } \\
\text { (Hg) }\end{array}$ \\
\hline $\begin{array}{c}\text { West Fork Cane Branch Nov, 15, } \\
\text { 1973 - }\end{array}$ & 0 & 0 & 1 & 1 & 6 & $\begin{array}{c}\text { Dissolved } \\
\text { zinc } \\
(\mathrm{Zn})\end{array}$ \\
\hline
\end{tabular}


in a sample from West Fork Cane Branch, 1973

liter, except as indicated]

\begin{tabular}{|c|c|c|c|c|c|c|c|c|}
\hline $\begin{array}{l}\text { Dissolved } \\
\text { potassium } \\
\text { (K) }\end{array}$ & $\begin{array}{c}\text { Bicarbonate } \\
\left(\mathrm{HCO}_{3}\right)\end{array}$ & $\begin{array}{c}\text { Dissolved } \\
\text { sulfate } \\
\left(\mathrm{SO}_{4}\right)\end{array}$ & $\begin{array}{l}\text { Dissolved } \\
\text { chloride } \\
\text { (CI) }\end{array}$ & $\begin{array}{l}\text { Dissolved } \\
\text { fluoride } \\
\text { (F) }\end{array}$ & $\begin{array}{c}\text { Dissolved } \\
\text { solids } \\
\text { (residue } \\
\text { at } 180^{\circ} \mathrm{C} \text { ) }\end{array}$ & $\begin{array}{l}\text { Hardness } \\
(\mathrm{Ca}, \mathrm{Mg})\end{array}$ & $\begin{array}{c}\text { Specific } \\
\text { conductance } \\
(\mu \mathrm{mhos})\end{array}$ & $\mathrm{pH}$ \\
\hline 1.1 & 4 & 5.4 & 0.6 & 0.1 & 24 & 7 & 23 & 6.6 \\
\hline
\end{tabular}

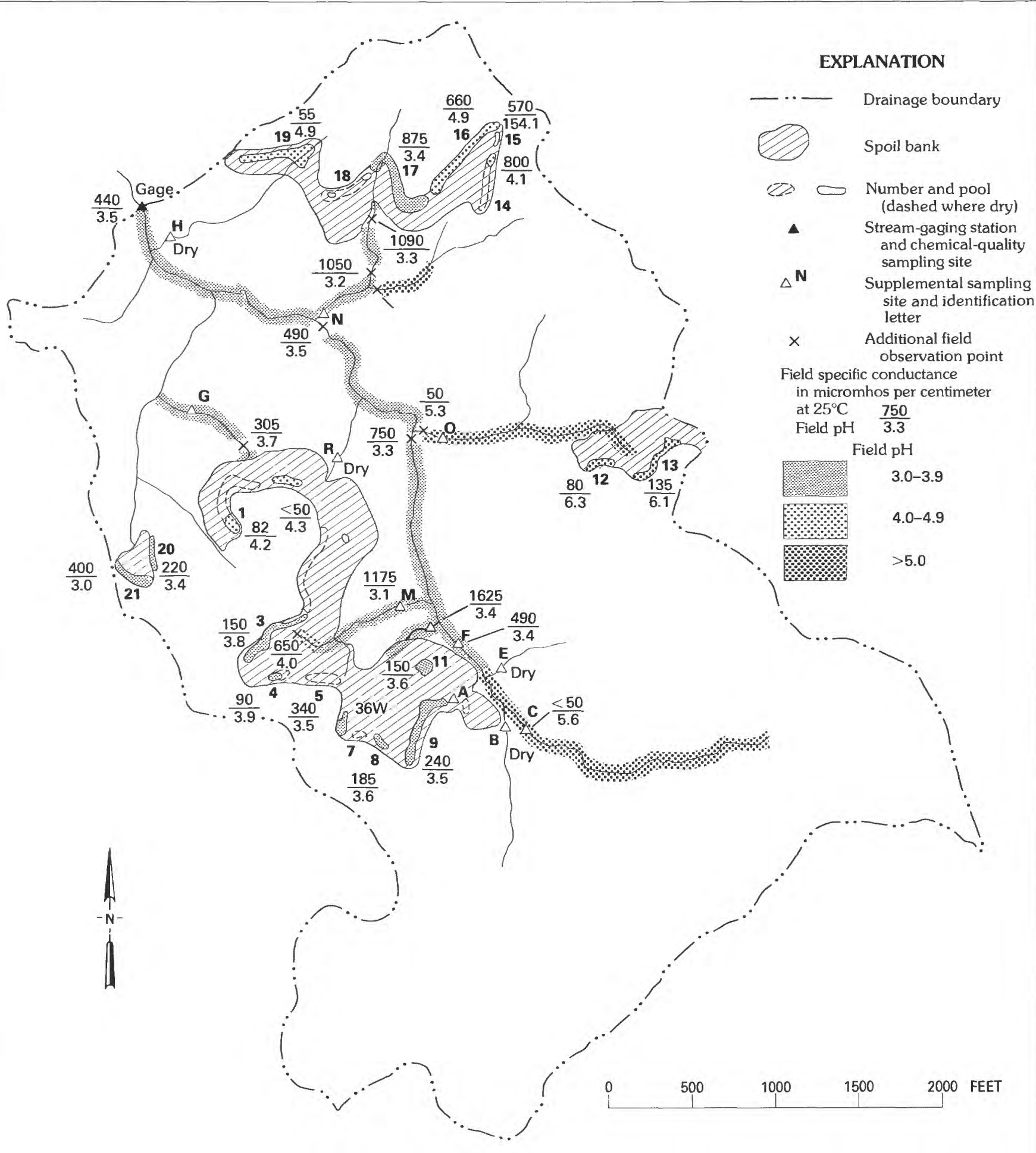

FIGURE 10.-Specific conductance and pH of water in pools, tributaries, and main stem of Cane Branch on September 11 and $12,1973$. 
TABLE 7.-Chemical analyses of common constituents in samples [Results in milligrams per

\begin{tabular}{|c|c|c|c|c|c|c|c|c|}
\hline & $\begin{array}{l}\text { Location and } \\
\text { date (1973) } \\
\text { of sample }\end{array}$ & $\begin{array}{l}\text { Dissolved } \\
\text { silica } \\
\left(\mathrm{SiO}_{2}\right)\end{array}$ & $\begin{array}{c}\text { Dissolved } \\
\text { aluminum } \\
\text { (Al) } \\
(\mu \mathrm{g} / \mathrm{L})\end{array}$ & $\begin{array}{c}\text { Dissolved } \\
\text { iron } \\
(\mathrm{Fe}) \\
(\mathrm{mg} / \mathrm{L})\end{array}$ & $\begin{array}{c}\text { Dissolved } \\
\text { manganese } \\
(\mathrm{Mn}) \\
(\mu \mathrm{g} / \mathrm{L})\end{array}$ & $\begin{array}{c}\text { Dissolved } \\
\text { calcium } \\
\text { (Ca) }\end{array}$ & $\begin{array}{l}\text { Dissolved } \\
\text { magnesium } \\
\text { (Mg) }\end{array}$ & $\begin{array}{l}\text { Dissolved } \\
\text { sodium } \\
\text { (Na) }\end{array}$ \\
\hline Pool & 2, Nov. 14 -- & 0.1 & 330 & 50 & 230 & 0.9 & 0.5 & 0.2 \\
\hline Pool & 3, Nov. 13 & 1.6 & 1,500 & 400 & 600 & 5.2 & 1.3 & .3 \\
\hline Pool & 4, Nov. 14 & .9 & 650 & 90 & 400 & 2.2 & .7 & .3 \\
\hline Pool & 9, Nov. 14 & 2.9 & 1,700 & 580 & 1,200 & 16 & 5.2 & .6 \\
\hline Pool & 11, Nov. $14 \ldots$ & .1 & 1,500 & 120 & 280 & 3.5 & 1.2 & .3 \\
\hline Pool & 12 , Nov. 15 & 6.1 & 90 & 70 & 550 & 5.2 & 6.7 & .3 \\
\hline Pool & 13 , Nov. 15 & $-\cdots$ & 10 & 60 & 25 & --- & --- & --- \\
\hline Pool & 16, Nov. 15 & 3.3 & 10 & 30 & 140 & 74 & 7.5 & .6 \\
\hline Pool & 17 , Nov. 15 & -- & 3,100 & 3,200 & 5,000 & --- & --- & --- \\
\hline Pool & 18 , Nov. 14 & 1.3 & 1,300 & 180 & 1,200 & 12 & 2.1 & .3 \\
\hline Pool & 19, Nov. 15 & 1.5 & 30 & 80 & 100 & 1.3 & .6 & .3 \\
\hline
\end{tabular}

TABLE 8,-Chemical analyses of minor elements in samples from selected pools in Cane Branch study area, 1973 [Results in micrograms per liter]

\begin{tabular}{|c|c|c|c|c|c|c|c|c|}
\hline $\begin{array}{l}\text { Location and } \\
\text { date (1973) } \\
\text { of sample }\end{array}$ & $\begin{array}{l}\text { Dissolved } \\
\text { cadmium } \\
\text { (Cd) }\end{array}$ & $\begin{array}{c}\text { Dissolved } \\
\text { chromium } \\
\text { (Cr) }\end{array}$ & $\begin{array}{c}\text { Dissolved } \\
\text { cobalt } \\
\text { (Co) }\end{array}$ & $\begin{array}{c}\text { Dissolved } \\
\text { copper } \\
\text { (Cu) }\end{array}$ & $\begin{array}{c}\text { Dissolved } \\
\text { lead } \\
(\mathrm{Pb})\end{array}$ & $\begin{array}{c}\text { Dissolved } \\
\text { mercury } \\
(\mathrm{Hg})\end{array}$ & $\begin{array}{l}\text { Dissolved } \\
\text { zinc } \\
(\mathrm{Zn})\end{array}$ & $\begin{array}{c}\text { Dissolved } \\
\text { arsenic } \\
\text { (As) }\end{array}$ \\
\hline Pool 2, Nov. 14 & 0 & 0 & 5 & 1 & 6 & 0.2 & 30 & -- \\
\hline Pool 3, Nov. 13 & 0 & 2 & 14 & 5 & 6 & .0 & 60 & 0 \\
\hline Pool 4, Nov. 14 & 0 & 0 & 7 & 3 & 4 & .0 & 40 & 0 \\
\hline Pool 9, Nov. 14 & 0 & 0 & 23 & 9 & 6 & .1 & 100 & -- \\
\hline Pool 11, Nov. 14 & 0 & 0 & 9 & 4 & 6 & .0 & 70 & 1 \\
\hline Pool 12, Nov. 15 & 0 & 0 & 4 & 0 & 7 & .0 & 50 & 12 \\
\hline Pool 13, Nov. 15 & 0 & 0 & 0 & 3 & 5 & .0 & 30 & 3 \\
\hline Pool 16, Nov. 15 - & 1 & 0 & 3 & 0 & 6 & .0 & 20 & 2 \\
\hline Pool 17, Nov. 15 & 0 & 1 & 60 & 5 & 3 & .0 & 310 & 0 \\
\hline Pool 18, Nov. 14 & 0 & 0 & 14 & 2 & 9 & .2 & 50 & -- \\
\hline Pool 19, Nov. 15 -- & 1 & 0 & 1 & 3 & 10 & .0 & 20 & 0 \\
\hline
\end{tabular}

The sulfate and specific conductance in 1973-74 (an indicator of dissolved-solids content) were about onetenth of the values reported for 1956-59 (see specific conductance versus time for pools 2,3 , and 9, fig. 11). Small amounts of free acidity, $0.5 \mathrm{mg} / \mathrm{L}$ or less, occurred with $\mathrm{pH}$ in the range of 3.8 to 5.1 units, similar to amounts reported for 1960-66. The water contained less iron, less than $0.6 \mathrm{mg} / \mathrm{L}$, but the dissolvedmanganese content of the water had not changed significantly from the 1960-66 values. A few minor elements, particularly cobalt, copper, lead, and zinc, occurred at barely detectable levels.

Pools 12 and 13 are in a small mined area on the northeast side of the basin (fig. 10). Pool 12 contained about the same range of concentration of constituents in 1973 as it contained in 1966. Pool 13 was not acidic in 1966 or in 1973, indicating that the water in the pool is not influenced by iron sulfide minerals.

Pools 14 to 19 are on the north side of the Cane Branch basin (fig. 10). At the time of sampling, pool 14

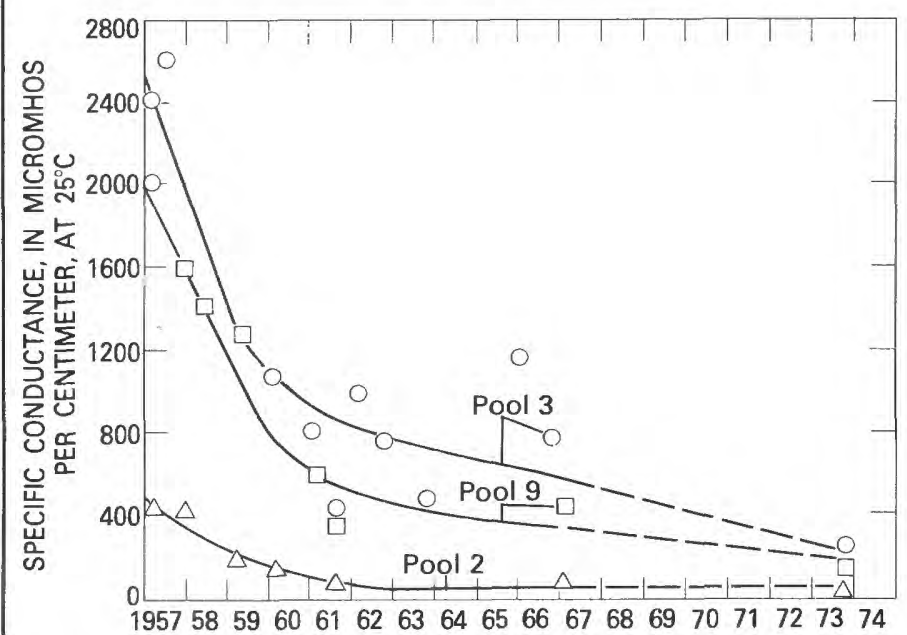

Figure, 11,-Decrease with time in specific conductance of water in selected pools on the southwest spoil bank. 


\begin{tabular}{|c|c|c|c|c|c|c|c|c|c|}
\hline $\begin{array}{c}\text { Dissolved } \\
\text { potassium } \\
\text { (K) }\end{array}$ & $\begin{array}{c}\text { Bicarbonate } \\
\left(\mathrm{HCO}_{3}\right)\end{array}$ & $\begin{array}{c}\text { Dissolved } \\
\text { sulfate } \\
\left(\mathrm{SO}_{4}\right)\end{array}$ & $\begin{array}{c}\text { Dissolved } \\
\text { chloride } \\
\text { (Cl) }\end{array}$ & $\begin{array}{l}\text { Dissolved } \\
\text { fluoride } \\
\text { (F) }\end{array}$ & $\begin{array}{c}\text { Dissolved } \\
\text { solids } \\
\text { (residue } \\
\text { at } 180^{\circ} \mathrm{C} \text { ) }\end{array}$ & $\begin{array}{l}\text { Hardness } \\
\text { (Ca, Mg) }\end{array}$ & $\begin{array}{l}\text { Total } \\
\text { acidity } \\
\text { as H+ }\end{array}$ & $\begin{array}{c}\text { Specific } \\
\text { conductance } \\
(\mu \mathrm{mhos})\end{array}$ & $\mathrm{pH}$ \\
\hline 2.5 & 0 & 37 & .1 & .1 & 54 & 18 & 0.5 & 156 & 3.8 \\
\hline 2.8 & 0 & 19 & .2 & .1 & 29 & 8 & .2 & 80 & 4.1 \\
\hline 3.0 & 0 & 78 & 1.2 & .4 & 117 & 61 & .5 & 240 & 3.8 \\
\hline 2.1 & 0 & 33 & .6 & .1 & 55 & 14 & .5 & 151 & 3.8 \\
\hline 3.2 & 5 & 200 & .7 & .3 & 338 & 220 & -.. & 461 & 6.7 \\
\hline --- & - & --- & $\ldots$ & -- & $\ldots$ & - & --- & 772 & 3.1 \\
\hline 2.9 & 0 & 55 & .1 & .3 & 80 & 39 & .4 & 185 & 3.9 \\
\hline 1.6 & 2 & 6.2 & .6 & .0 & 25 & 6 & --- & 24 & 5.3 \\
\hline
\end{tabular}

was almost dry and pool 17 drained into pool 18, which in turn was draining through a breach in the spoil pile, maintaining a small flow of water into the northbranching tributary (see fig. 10). The water in pools 16 and 18 is similar in type to water in pools 1 through 11. Water in pool 16 was slightly less mineralized in 1973 than in 1966; however, the water flowing through pool 18 was appreciably less mineralized than in 1966 , possibly because the water was in contact with iron sulfide minerals for a shorter time than when the pool did not drain. Noteworthy is that pool 19 had reversed the trend, cited by Musser and Pickering (in Collier and others, 1970, p. C17-C18), of becoming more mineralized since 1961 . The water contained only $6.2 \mathrm{mg} / \mathrm{L}$ of sulfate in 1973 compared with $238 \mathrm{mg} / \mathrm{L}$ in 1966. Pool 19 was one of the few pools containing bicarbonate ions.

Pools 20 and 21, new pools on the west side of the basin, were not sampled for chemical analyses, but field $\mathrm{pH}$ and specific-conductance measurements, as shown on figure 10 , indicate that the water was acidic and probably contained appreciable concentrations of sulfate ion.

In summary, since 1956-59 some pool waters, as in the southwest spoil bank, have shown a tenfold reduction in sulfate concentration and specific conductance and are less acidic. The rate of reduction was very rapid during the first 5 years and then slowed after about 1961 or 1962 . The bedrock in the highwall, along with the overlying weathered soil, has slumped into the strip pits since their abandonment, resulting in the restriction of air and water circulation to the sulfidebearing rocks in the highwall and probably contributing to the decrease in mineralization in the pools. By 1973 , the specific conductance of some pool waters had begun to level off at about 100 micromhos, or about that of natural surface water. The exceptions to large reductions in concentration were the metals aluminum, iron, and manganese, which continued, collectively, to exceed $1 \mathrm{mg} / \mathrm{L}$ in acidic waters.

\section{TRIBUTARIES OF CANE BRANCH}

Tributary streams of Cane Branch carry overland runoff from precipitation and ground-water discharge from the rocks and seepage from the spoil piles into Cane Branch. Locations of the tributaries and sampling points are shown on figure 10 . The only streamflow that never was affected by strip mining was sampled at site $\mathrm{C}$, in the headwaters of Cane Branch. In September 1973 , the conductivity of the water at site $\mathrm{C}$ was less than 50 micromhos (fig. 10), the minimum reading on the instrument, and the field $\mathrm{pH}$ was 5.6 units. This water was low in dissolved solids; however, in November there was insufficient water at this site to obtain a sample for chemical analysis. Downstream from site $\mathrm{C}$, water that has been in contact with iron sulfide minerals in the spoil piles of the southwest strip mine enters Cane Branch from seeps and tributary streams that carry leachate from the spoil piles. Field specific conductance and $\mathrm{pH}$ of water in the pools and water entering Cane Branch upstream from the gaging station in September 1973 are shown in figure 10. At that time Cane Branch was near base flow at $0.15 \mathrm{ft}^{3} / \mathrm{s}$.

Upstream from the spoil piles, water in Cane Branch is slightly acidic and of low mineralization. At sites $P$ and $M$, tributary streams draining the southwest spoil piles enter Cane Branch; the water in the Branch becomes acidic, and dissolved-mineral content increases about tenfold. Site $3 \mathrm{GW}$ is the beginning of ground-water discharge or seepage from the spoil pile just below pool 3. Additional tributaries sampled at sites $\mathrm{G}, \mathrm{N}$, and $\mathrm{O}$ enter Cane Branch upstream from the gaging station. Chemical analyses of water from tributary streams are shown in tables 9 and 10 .

Water in the tributaries is a calcium, magnesium, sulfate type, low in $\mathrm{pH}$, with appreciable quantities of 
TABLE 9.-Chemical analyses of common constituents in [Results in milligrams per

\begin{tabular}{|c|c|c|c|c|c|c|c|}
\hline $\begin{array}{l}\text { Location and } \\
\text { date (1973) } \\
\text { of sample }\end{array}$ & $\begin{array}{c}\text { Dissolved } \\
\text { silica } \\
\left(\mathrm{SiO}_{2}\right)\end{array}$ & $\begin{array}{c}\text { Dissolved } \\
\text { aluminum } \\
(\mathrm{Al}) \\
(\mu \mathrm{g} / \mathrm{L})\end{array}$ & $\begin{array}{c}\text { Dissolved } \\
\text { iron } \\
(\mathrm{Fe}) \\
(\mu \mathrm{g} / \mathrm{L})\end{array}$ & $\begin{array}{c}\text { Dissolved } \\
\text { manganese } \\
(\mathrm{Mn}) \\
(\mu \mathrm{g} / \mathrm{L})\end{array}$ & $\begin{array}{l}\text { Dissolved } \\
\text { calcium } \\
\text { (Ca) }\end{array}$ & $\begin{array}{c}\text { Dissolved } \\
\text { magnesium } \\
(\mathrm{Mg})\end{array}$ & $\begin{array}{l}\text { Dissolved } \\
\text { sodium } \\
\text { (Na) }\end{array}$ \\
\hline Site 3GW, Nov. 13 & 31 & 7,500 & 3,800 & 7,200 & 31 & 26 & 1.7 \\
\hline Site G, Nov. 14 & 18 & 5,300 & 5,900 & 2,500 & 3.5 & 5.8 & .3 \\
\hline Site M, Nov. 13 & 30 & 12,000 & 2,200 & 14,000 & 43 & 32 & 2.0 \\
\hline Site N., Nov. 13 --_--- & 14 & 4,600 & 660 & 13,000 & 50 & 22 & 1.7 \\
\hline Site 0 , Nov. 13 & 6.9 & 180 & 110 & 550 & 3.0 & 3.3 & .3 \\
\hline Site P, Nov. 13 & 20 & 10,000 & 2,300 & 40,000 & 100 & 48 & 2.6 \\
\hline
\end{tabular}

silica, aluminum, iron, and manganese. With the exception of water at site $O$, the tributary waters were more mineralized than was water in the pools. Water from site $\mathrm{O}$, which has drained from the easternmost stripmine area, is acidic and low in dissolved solids because pools 12 and 13 , and their associated spoil piles, contribute low-mineralized water to this tributary. Apparently there are fewer iron sulfide minerals in the drainage area contributory to site $O$ than in the other tributary drainage areas. The amount of dissolved constituents in water from all sites is within the range of samples taken in 1958-66. Although the overall water quality of base flow has not improved, the dissolvediron concentration has decreased at all sites.

\section{CANE BRANCH}

The effect of acid mine drainage on the chemical quality of water in Cane Branch has been measured since 1956 by periodic sampling at the Cane Branch gaging station downstream from the mined area. Chemical analyses of water from Cane Branch for 1967-74 are given in tables 11 and 12. Selected chemical analyses for 1955-66 are given in part C of this series (in Collier and others, 1970, p. C23).

Some indication of the quality of the water in the Cane Branch study area before the April 1955 mining is given by Musser and Whetstone (in Collier and others, 1964, fig. 27, p. B38-B39), who noted that, for several small streams not influenced by mining, the median dissolved-solids concentration was $20 \mathrm{mg} / \mathrm{L}$ and the $\mathrm{pH}$ ranged from 5.2 to 7.6 units.

From January to June 1956, the mine debris affected the chemical character of the Cane Branch water, altering it to a calcium and magnesium sulfate type. The dissolved-solids concentration increased from 31 to $195 \mathrm{mg} / \mathrm{L}$.

From June 1956 to December 1959, the dissolvedsolids concentration of Cane Branch ranged from 76 to $1,460 \mathrm{mg} / \mathrm{L}$. The principal ionic species in solution were hydrogen, aluminum, iron, manganese, calcium, magnesium, and sulfate. Silica made up about 4 percent of the dissolved-solids content and ranged in concentration from 1 to $19 \mathrm{mg} / \mathrm{L}$. The sulfate ion accounted for about 70 percent of the dissolved solids and ranged from 46 to $1,220 \mathrm{mg} / \mathrm{L}$.

The high flows of 1974 carried an average of 237 tons of dissolved solids, of which 155 tons were sulfate, from each square mile of drainage of the Cane Branch study area (table 13). These values were higher than for most of the years from 1957 to 1966 , as shown in table 13. However, the concentrations of $104 \mathrm{mg} / \mathrm{L}$ and $68 \mathrm{mg} / \mathrm{L}$ for dissolved solids and sulfate, respectively, were the lowest for the same period. The effect of time and the relation of loads to discharge is not so obvious in table 13 as they are in figure 12. Helton Branch tends to show much less response in loads of dissolved solids to increases in runoff than Cane Branch (see fig. 12A). Of considerable significance is the change with

TABLE 10.-Chemical analyses of minor elements in samples from selected tributaries of Cane Branch, 1973 [Results in micrograms per liter]

\begin{tabular}{|c|c|c|c|c|c|c|c|c|}
\hline $\begin{array}{l}\text { Location and } \\
\text { date (1973) } \\
\text { of sample }\end{array}$ & $\begin{array}{l}\text { Dissolved } \\
\text { cadmium } \\
\text { (Cd) }\end{array}$ & $\begin{array}{c}\text { Dissolved } \\
\text { chromium } \\
\text { (Cr) }\end{array}$ & $\begin{array}{c}\text { Dissolved } \\
\text { cobalt } \\
\text { (Co) }\end{array}$ & $\begin{array}{c}\text { Dissolved } \\
\text { copper } \\
(\mathrm{Cu})\end{array}$ & $\begin{array}{l}\text { Dissolved } \\
\text { lead } \\
\text { (Pb) }\end{array}$ & $\begin{array}{c}\text { Dissolved } \\
\text { mercury } \\
(\mathbf{H g})\end{array}$ & $\begin{array}{l}\text { Dissolved } \\
\text { zinc } \\
(\mathrm{Zn})\end{array}$ & $\begin{array}{c}\text { Dissolved } \\
\text { arsenic } \\
\text { (As) }\end{array}$ \\
\hline Site 3GW, Nov. 13 & 0 & 2 & 66 & 1 & 4 & 0.0 & 220 & 0 \\
\hline Site G, Nov. 14 & 1 & 0 & 47 & 6 & 8 & .1 & 120 & - \\
\hline Site M, Nov. 13 -- & 0 & 2 & 40 & 5 & 0 & 2.6 & 1,600 & 0 \\
\hline Site N, Nov. 13 - & 0 & 2 & 96 & 9 & 0 & 5.0 & 290 & 0 \\
\hline Site O, Nov. 13 - & 1 & 0 & 1 & 1 & 0 & .0 & 20 & 0 \\
\hline Site $\mathrm{P}$, Nov. 13 - & 0 & 2 & 74 & 9 & 1 & .0 & 200 & 6 \\
\hline
\end{tabular}


samples from selected tributaries of Cane Branch, 1973

liter, except as indicated]

\begin{tabular}{|c|c|c|c|c|c|c|c|c|c|}
\hline $\begin{array}{l}\text { Dissolved } \\
\text { potassium } \\
\text { (K) }\end{array}$ & $\begin{array}{c}\text { Bicarbonate } \\
\left(\mathrm{HCO}_{3}\right)\end{array}$ & $\begin{array}{c}\text { Dissolved } \\
\text { sulfate } \\
\left(\mathrm{SO}_{4}\right)\end{array}$ & $\begin{array}{l}\text { Dissolved } \\
\text { chloride } \\
\text { (Cl) }\end{array}$ & $\begin{array}{l}\text { Dissolved } \\
\text { fluoride } \\
\text { (F) }\end{array}$ & $\begin{array}{c}\text { Dissolved } \\
\text { solids } \\
\text { (residue } \\
\text { at } 180^{\circ} \mathrm{C} \text { ) }\end{array}$ & $\begin{array}{l}\text { Hardness } \\
\text { (Ca, Mg) }\end{array}$ & $\begin{array}{l}\text { Total } \\
\text { acidity } \\
\text { as } \mathrm{H}+\end{array}$ & $\begin{array}{c}\text { Specific } \\
\text { conductance } \\
(\mu \mathrm{mhos})\end{array}$ & $\mathbf{p H}$ \\
\hline 4.5 & 0 & 320 & 0.1 & 0.7 & 494 & 180 & 3.4 & 1,000 & 2.9 \\
\hline 45 & 0 & 430 & .1 & .7 & 705 & 240 & 3.9 & 1,280 & 2.8 \\
\hline 3.3 & 0 & 290 & .8 & .3 & 445 & 220 & 1.5 & 752 & 3.3 \\
\hline 1.3 & 0 & 23 & .7 & .1 & 51 & 21 & $\cdots$ & 73 & 4.6 \\
\hline
\end{tabular}

the passage of time of the ratio of the dissolved load per square mile to water discharge (fig. 12B). The loaddischarge ratio for Helton Branch showed no change with the variation in runoff, whereas the ratio varied considerably with the discharge from Cane Branch. Generally, the dissolved load showed a downward trend in Cane Branch basin after the peak water year of 1959. Although mineral loads are important in comparing year-to-year change and in determining trends in water quality, it is the concentration of the mineral and its components that are important to the life of aquatic organisms.

Loads of sulfate and dissolved solids passing Cane Branch gaging station during each month of water year 1974 are given in table 14. Data for water years 1957 and 1958 were reported by Musser and Whetstone (in Collier and others, 1964, p. B47) and for 1959-66 by Musser and Pickering (in Collier and others, 1970, p. C73-C74). The monthly load depends on both the amount of water passing the gaging station and the concentration of the chemical constituent in that water. Monthly loads were computed from mean concentrations using the appropriate discharge.

To examine the record of monthly loads transported by Cane Branch for significant changes during the period 1956-66, Musser and Pickering prepared a cumulative plot of runoff and dissolved-solids load. Figure 13 shows the Muser-Pickering curves with the addition of 1973-74 data. The slopes of the lines in figure 13 represent average concentrations on dissolved solids in the water; an increase or decrease in slope means that the average dissolved-solids concentration for that period increased or decreased, respectively, with time.

The bulk of the dissolved constituents in Cane Branch is contributed by direct runoff and seepage from the spoil banks. Changes in slope of the lines in figure 13 thus represent changes in the quantity of dissolved constituents contributed by these spoil-bank waters to Cane Branch. The average concentration of the dissolved solids during a period of time is defined by the slope of the line through all points for that period.
A plot (the inset on fig. 13) of dissolved-solids load for water year 1974 (237 tons) and corresponding runoff $\left(842 \mathrm{ft}^{3} / \mathrm{s}\right.$ per day) show a marked decrease in the slope of the line to about 30 percent, indicative of a lower mean concentration for water year 1974 (104 mg/L) compared with the 1960's.

\section{MPARISON OF CHEMICAL EROSION IN CANE BRANCH AND HELTON BRANCH STUDY AREAS}

The disturbance of the land surface in the Cane Branch area by strip mining has placed unweathered rocks at or near the surface. These exposed rocks allow the rate of chemical erosion to increase in the mined areas. With time, higher concentrations and loads of chemical constituents occur in the runoff from the mined areas than from the unmined areas.

An example compares the load of dissolved constituents being transported by Cane and Helton Branches at their gaging stations. The relation of the monthly water discharge and the monthly dissolved yield for Cane and Helton Branches depicted in figure 14 for 1956-58 and 1973-74 show that at a given water discharge the Cane Branch load is greater than the Helton Branch load. In both study areas, the greatest loads are transported during winter-type months when the water discharges are high. In both areas, also, winter discharges are distinct from summer discharges in dissolved-solids concentrations.

Noteworthy in figure 14 is that the 1973-74 monthly loads for Cane Branch have shifted significantly toward the weighted mean line of Helton Branch as mean concentrations in Cane Branch continue to decrease and as the stream basin gradually returns to the premining conditions represented by Helton Branch. It is likely that as time goes on, assuming no other changes take place in Cane Branch basin, the dissolved-solids concentration of Cane Branch will gradually decrease and the $\mathrm{pH}$ values will gradually increase. This may be regarded as the mine-age factor or the die-out curve. If this be the case, it will be many years before the quality of water in Cane Branch is reasonably similar to that of Helton Branch. 
TABLE 11.-Chemical analyses of common constituents of [All constituents in milligrams

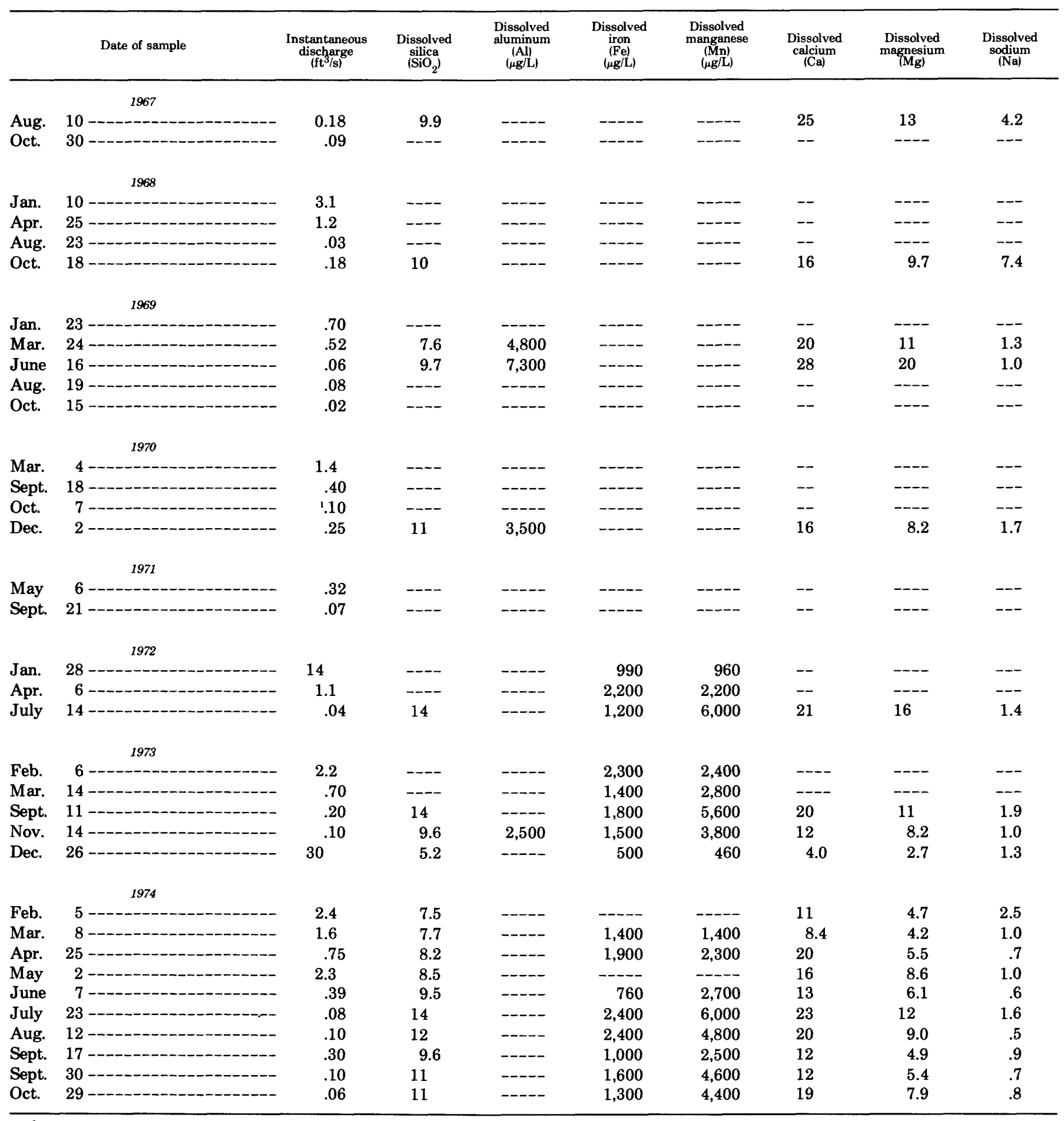

\footnotetext{
${ }^{1}$ Estimated.
} 
samples from Cane Branch near Parkers Lake, 1967-74

per liter except as noted]

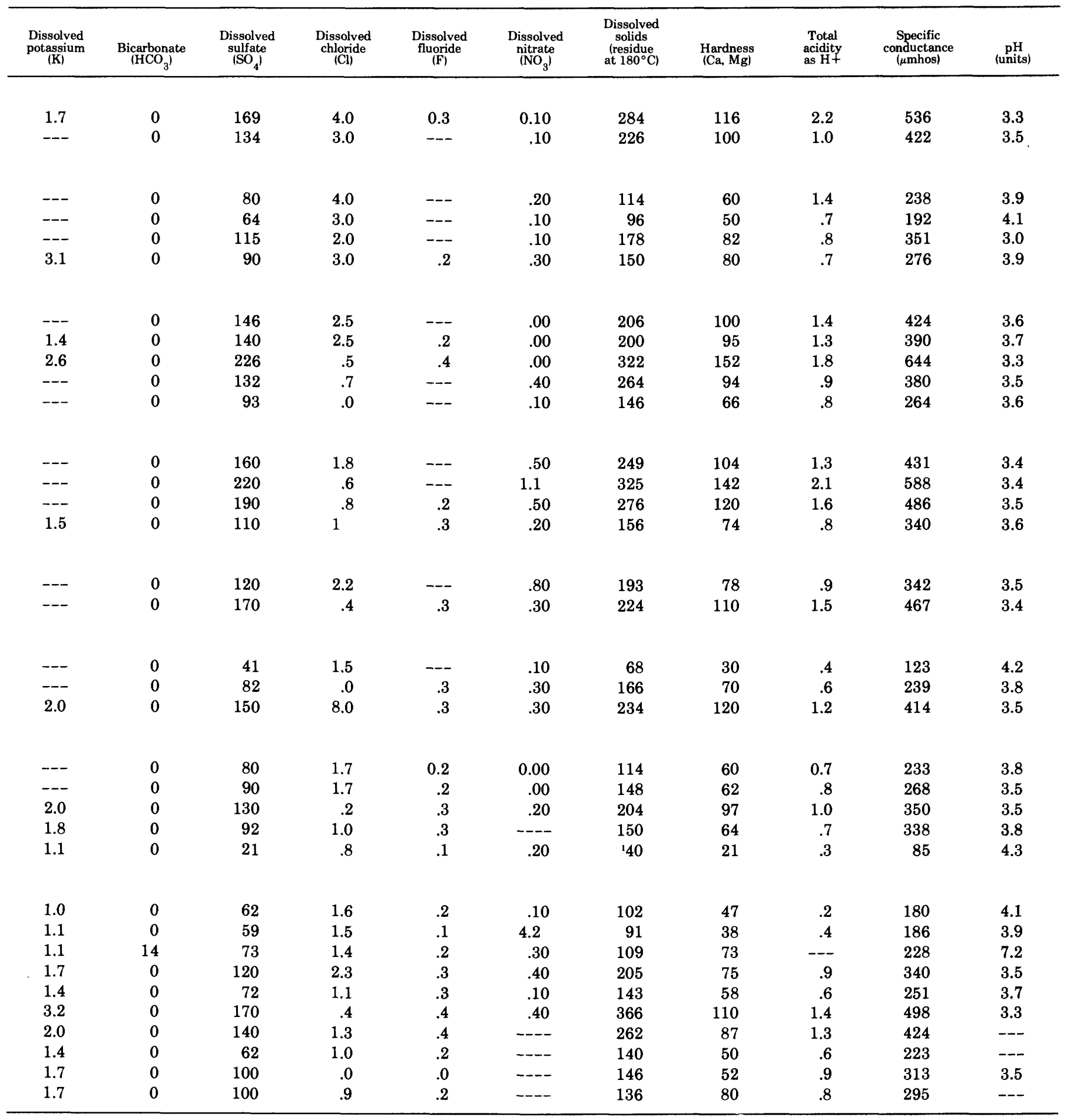


TABLE 12.-Chemical analyses of total and dissolved minor [All constituents in

\begin{tabular}{|c|c|c|c|c|c|c|c|c|}
\hline & Date of sample & $\begin{array}{l}\text { Dissolved } \\
\text { arsenic } \\
\text { (As) }\end{array}$ & $\begin{array}{c}\text { Total } \\
\text { arsenic } \\
\text { (As) }\end{array}$ & $\begin{array}{l}\text { Dissolved } \\
\text { cadmium } \\
\text { (Cd) }\end{array}$ & $\begin{array}{l}\text { Total } \\
\text { cadmium } \\
\text { (Cd) }\end{array}$ & $\begin{array}{c}\text { Dissolved } \\
\text { chromium } \\
\text { (Cr) }\end{array}$ & $\begin{array}{c}\text { Total } \\
\text { chromium } \\
\text { (Cr) }\end{array}$ & $\begin{array}{c}\text { Dissolved } \\
\text { cobalt } \\
(\mathbf{C o})\end{array}$ \\
\hline & 1973 & & & & & & & \\
\hline Nov. & 14 & - & -- & 0 & - & 0 & -- & 37 \\
\hline Dec. & 26 & 0 & -- & 3 & 0 & 1 & -- & 1 \\
\hline Apr. & 25 -- & 2 & 7 & 0 & 2 & 0 & 0 & 6 \\
\hline June & $7 \ldots$ & 0 & 0 & 3 & 1 & 1 & -- & 12 \\
\hline Aug. & $12---$ & 1 & 2 & 1 & 1 & 0 & 10 & 58 \\
\hline Sept. & $30--$ & 1 & 0 & 0 & 0 & 0 & $<10$ & 42 \\
\hline
\end{tabular}

TABLE 13.-Annual runoff, gross annual loads, and annual mean concentrations of selected chemical constituents at Cane Branch near Parkers Lake gaging station, water years 1957-66 and 1974 [e=estimated]

\begin{tabular}{|c|c|c|c|c|c|c|c|}
\hline \multirow[b]{2}{*}{$\begin{array}{l}\text { Water } \\
\text { year }^{2}\end{array}$} & \multirow[b]{2}{*}{$\begin{array}{c}\text { Annual } \\
\text { runoff } \\
{\left[\left(\mathrm{ft}^{3} / \mathrm{s}-\mathrm{d}\right) / \mathrm{mi}^{2}\right]}\end{array}$} & \multicolumn{3}{|c|}{$\begin{array}{l}\text { Gross annual load } \\
\text { (tons per square mile) }\end{array}$} & \multicolumn{3}{|c|}{$\begin{array}{c}\text { Annual mean concentration } \\
\text { (milligrams per liter) }\end{array}$} \\
\hline & & $\begin{array}{l}\text { Dissolved } \\
\text { solids }\end{array}$ & Sulfate & $\begin{array}{c}\text { Acidity } \\
\text { (equivalent } \\
\left.\mathrm{H}_{2} \mathrm{SO}_{4}\right)\end{array}$ & $\begin{array}{l}\text { Dissolved } \\
\text { solids }\end{array}$ & Sulfate & $\begin{array}{c}\text { Acidity } \\
\text { (equivalent } \\
\left.\mathrm{H}_{2} \mathrm{SO}_{4}\right)\end{array}$ \\
\hline 1957 & 580 & 227 & 147 & 55 & 145 & 94 & 35 \\
\hline 1958 & 619 & 219 & 140 & 51 & 131 & 84 & 31 \\
\hline 1959 & 280 & 189 & 121 & 61 & 250 & 160 & 81 \\
\hline 1960 & 691 & 414 & 275 & 115 & 222 & 147 & 62 \\
\hline 1961 & 485 & 221 & 153 & 62 & 169 & 117 & 47 \\
\hline 1962 & 694 & 274 & 178 & 60 & 146 & 95 & 32 \\
\hline 1963 & 398 & ${ }^{3} 168 \mathrm{e}$ & --- & --- & ${ }^{5} 156 \mathrm{e}$ & -- & --- \\
\hline 1964 & 284 & ${ }^{4} 172 \mathrm{e}$ & --- & --- & ${ }^{5} 166 \mathrm{e}$ & -- & --- \\
\hline 1965 & 427 & ${ }^{4} 191 \mathrm{e}$ & $-\cdots$ & $\cdots$ & ${ }^{5} 166 \mathrm{e}$ & --- & --- \\
\hline 1966 & 180 & 106 & 64 & 26 & 218 & 132 & 53 \\
\hline 1974 & 842 & 237 & 155 & 20 & 104 & 68 & 46 \\
\hline
\end{tabular}

${ }^{\mathrm{l}}$ Annual mean concentration $(\mathrm{mg} / \mathrm{L})=$ annual load $\left(\right.$ tons $\left./ \mathrm{mi}^{2}\right) /\left(\mathrm{ft}^{3} / \mathrm{s}-\mathrm{d}\right) / \mathrm{mi}^{2} \times .0027$.

${ }^{2}$ Values for water years 1957-66 from Collier, 1970, p. C27.

${ }^{3}$ Load based on annual runoff for 1963 and dissolved-solids load:runoff ratios for water years 1962 and 1964.

${ }^{4}$ Partial load data for water years 1964 and 1965 used to calculate an estimated total load for the 2 years. Proportioning of the total load between the 2 years was based on annual runoff for the 2 years.

${ }^{5}$ The identical estimated annual mean concentrations for water years 1964 and 1965 are the result of the nethod by which the annual loads for those 2 years were estimated.

The monthly runoff and yields of dissolved solids and sulfate transported by Cane Branch and Helton Branch are listed in tables 14 and 15. These data show that in the 1974 water year Cane Branch transported about 3.5 times more dissolved solids and about 8.5 times more sulfate than Helton Branch on a tons-persquare-mile basis. This is a substantial reduction from the 4.5 times more dissolved solids and about 10 times more sulfate reported by Collier and others (1964, p. B47) for the 2-year period 1957-58.

Noteworthy in table 13 and figure 12 (adapted from Collier and others, 1970 , fig. 16, p. C26) is that runoff, in cubic feet per second-day per square mile, for water year 1974 is the highest on record for water years 1957-66 and 1974 and that the dissolved-solids load for water year 1974, 237 tons per square mile is about 57 percent of the load for the high runoff year of 1960 and also is somewhat less than that for the high runoff year of 1962.

Musser and Pickering (in Collier and others, 1970, p. C27) discuss the difficulty of distinguishing maninduced changes in environmental studies: "Grouping of data on an annual basis can be used to mute seasonal variations, and expression of the leaching of soluble materials in terms of concentration can be used to mask the effect of year-to-year changes in precipita- 
elements in samples from Cane Branch near Parkers Lake, 1973-74

micrograms per liter]

\begin{tabular}{|c|c|c|c|c|c|c|c|c|c|c|}
\hline $\begin{array}{c}\text { Total } \\
\text { Cobalt } \\
\text { (Co) }\end{array}$ & $\begin{array}{c}\text { Dissolved } \\
\text { Cogper } \\
\text { (Cu) }\end{array}$ & $\begin{array}{c}\text { Total } \\
\text { Copper } \\
\text { (Cu) }\end{array}$ & $\begin{array}{c}\text { Dissolved } \\
\text { lead } \\
(\mathrm{Pb})\end{array}$ & $\begin{array}{l}\text { Total } \\
\text { lead } \\
(\mathrm{Pb})\end{array}$ & $\begin{array}{c}\text { Dissolved } \\
\text { mercury } \\
\text { (Hg) }\end{array}$ & $\underset{\substack{\text { Total } \\
\text { mercury } \\
\text { (Hg) }}}{\text { (Hg) }}$ & $\begin{array}{c}\text { Dissolved } \\
\text { selenium } \\
\text { (Se) }\end{array}$ & $\begin{array}{c}\text { Total } \\
\text { selenium } \\
\text { (Se) }\end{array}$ & $\begin{array}{l}\text { Dissolved } \\
\text { zinc } \\
\text { (Zn) }\end{array}$ & $\begin{array}{l}\text { Total } \\
\text { zinc } \\
(\mathrm{Zn})\end{array}$ \\
\hline -- & 3 & -- & 8 & -- & .0 & -- & -- & -- & 70 & --- \\
\hline 10 & 10 & 6 & 25 & 35 & .0 & --- & 18 & -- & 100 & 120 \\
\hline 6 & 2 & 10 & 0 & 0 & .2 & .2 & 1 & 3 & 80 & 100 \\
\hline 28 & 2 & 1 & 1 & 2 & .0 & .0 & 9 & 9 & 80 & 110 \\
\hline 58 & 9 & 12 & 10 & 17 & .1 & .1 & -- & 1 & 180 & 190 \\
\hline 40 & 5 & 7 & 2 & 0 & .0 & .0 & -- & -- & 110 & 110 \\
\hline
\end{tabular}

TABLE 14.-Dissolved solids and sulfate concentrations and loads, Cane Branch near Parkers Lake, October 1973 to September 1974

\begin{tabular}{|c|c|c|c|c|c|c|c|}
\hline \multirow{3}{*}{ Date } & \multirow{3}{*}{$\begin{array}{l}\text { Average } \\
\text { daily } \\
\left(\mathrm{ft}^{3} / \mathrm{s}\right)\end{array}$} & \multicolumn{2}{|c|}{ Mean discharge } & \multirow{2}{*}{\multicolumn{2}{|c|}{ Dissolved solids }} & \multirow{2}{*}{\multicolumn{2}{|c|}{ Sulfate }} \\
\hline & & \multirow{2}{*}{$\begin{array}{c}\text { Average daily } \\
\text { unit area } \\
{\left[\left(\mathrm{ft}^{3} / \mathrm{s} / / / \mathrm{mi}^{2}\right]\right.}\end{array}$} & \multirow{2}{*}{$\begin{array}{c}\text { Total daily } \\
\text { unit area } \\
{\left[\left[\mathrm{ft}^{3} / \mathrm{s}-\mathrm{d}\right) / \mathrm{mi}^{2}\right]}\end{array}$} & & & & \\
\hline & & & & $\overline{(\mathrm{mg} / \mathrm{L})}$ & (tons $\left./ \mathrm{mi}^{2}\right)$ & $\overline{(\mathrm{mg} / \mathrm{L})}$ & (tons $\left./ \mathrm{mi}^{2}\right)$ \\
\hline \multicolumn{8}{|l|}{1973} \\
\hline October ------ & 0.32 & 0.48 & 15.0 & 180 & 7.5 & 103 & 4.1 \\
\hline November ---- & 2.10 & 3.13 & 93.9 & 110 & 27.8 & 67 & 17.0 \\
\hline December ---- & 2.18 & 3.25 & 101.0 & 105 & 28.7 & 65 & 17.7 \\
\hline January ----- & 4.42 & 6.60 & 204.0 & 85 & 46.7 & 58 & 31.9 \\
\hline February -- --- & 2.51 & 3.75 & 105.0 & 100 & 28.4 & 65 & 18.4 \\
\hline March - - & - 1.80 & 2.69 & 83.4 & 110 & 24.5 & 70 & 15.8 \\
\hline April ------- & 2.42 & 3.61 & 108.0 & 100 & 20.1 & 65 & 19.0 \\
\hline May --- & 0.81 & 1.21 & 37.5 & 140 & 14.3 & 85 & 8.6 \\
\hline June - - & 1.04 & 1.55 & 46.4 & 130 & 16.6 & 80 & 10.0 \\
\hline July ------ & 0.13 & 0.19 & 5.9 & 230 & 3.7 & 125 & 2.0 \\
\hline
\end{tabular}

tion and runoff; but these analytical manipulations do not completely eliminate the effect of natural variations in the hydrologic cycle." However, the general picture obtained from figures 12 and 13 is the same. Chemical weathering in Cane Branch basin resulted from strip mining of coal in 1955, 1956, and 1959. Following cessation of mining, the rate of chemical weathering gradually decreased until water year 1966 , when it was slightly less than that observed in 1957 following initial mining in the study area. Heavy runoff in 1974 increased the load somewhat compared with the loads transported in several years of the 1960 's, but the rate per unit of runoff was sharply reduced. The rate of chemical weathering, however, was still greater than that prior to the initial disruption of bedrock in 1955 .
It has been assumed that any gross differences in chemical erosion between Cane Branch and Helton Branch observed during the study could be attributed to mining of coal in the Cane Branch basin.

A distinct difference was observed between the load of dissolved solids transported by the two basins. On a yearly basis, the dissolved-solids loads removed from the Cane Branch study area were four to eight times greater than those removed from the Helton Branch study area. A better quantitative comparison of rates can be made by considering what portion of the dissolved material is received by each area in precipitation.

The measured yields in table 16 show the dissolved solids contributed to the stream by precipitation and by chemical degradation in the study area. The mineral 


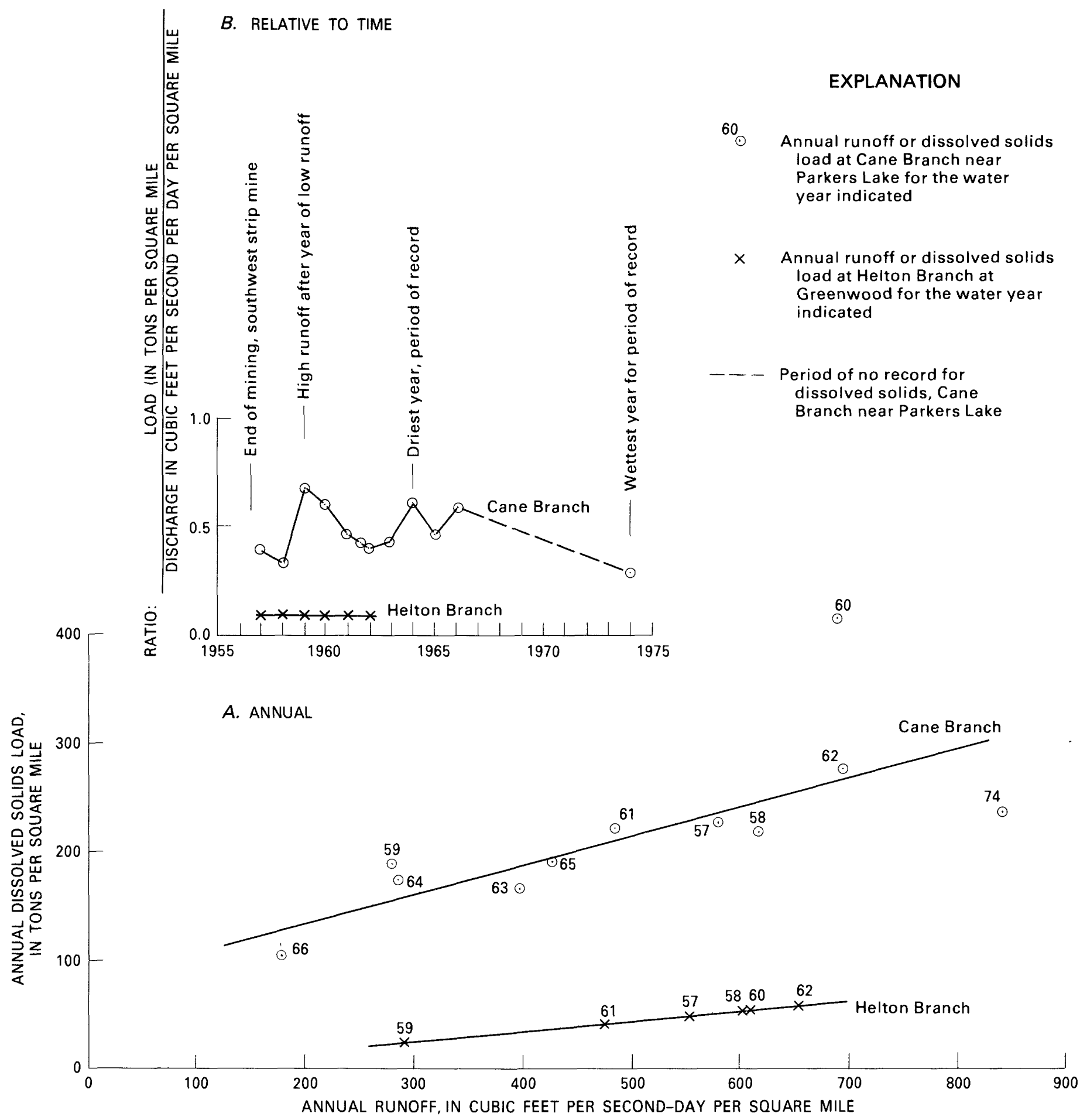

Figure 12.-Relation of runoff and dissolved-solids load, 1957-66 and 1974 water years: $A$, annually, and $B$, relative to time. 


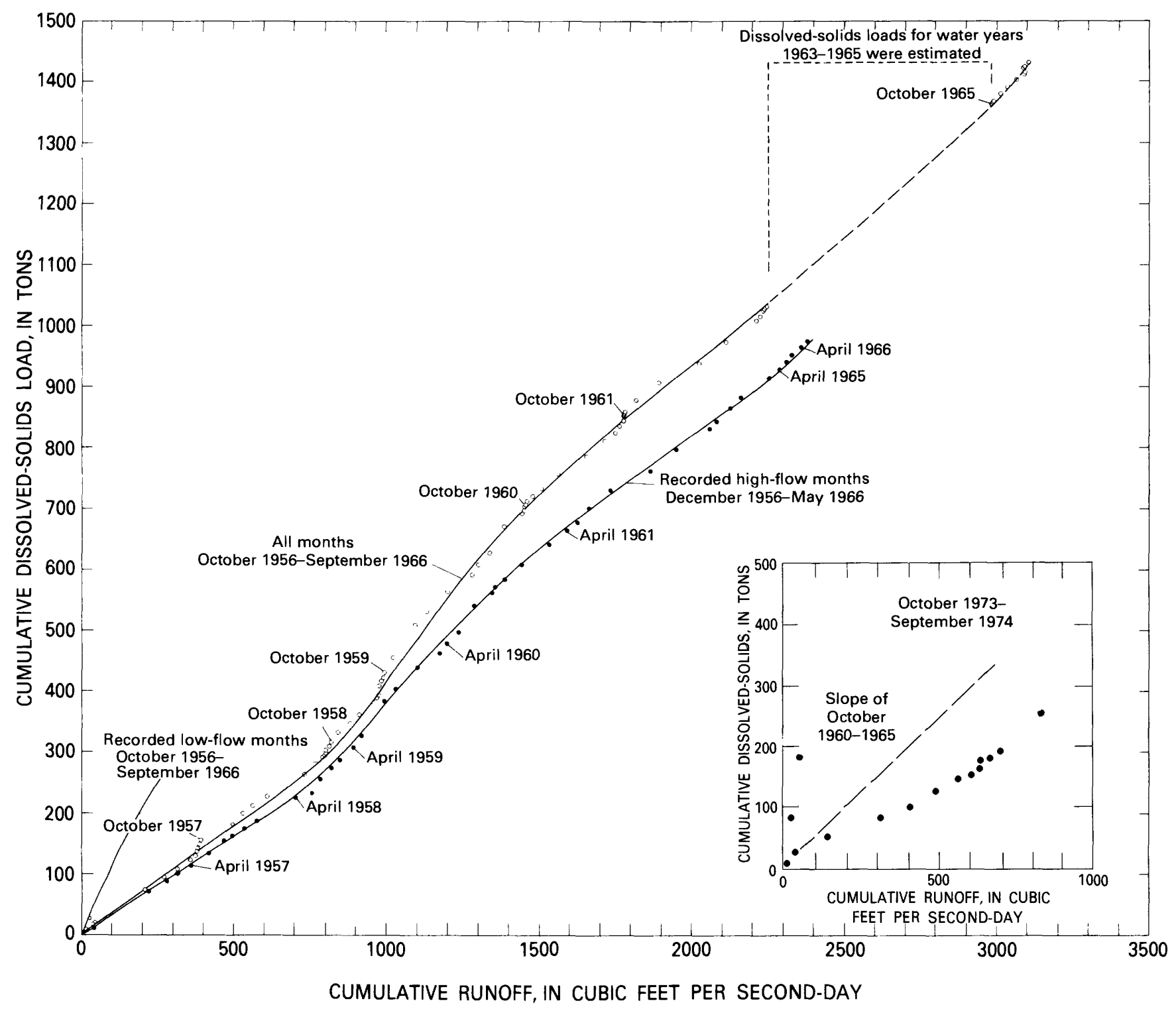

FIGURE 13.-Changes in relation of cumulative dissolved-solids load to cumulative runoff, Cane Branch gaging station, water years 1957-66 and 1974.

concentration attributable to precipitation, $8 \mathrm{mg} / \mathrm{L}$ (Collier and others, 1964, p. B46), was subtracted from the measured concentration in 1957-62. Corrected concentrations were used, $15 \mathrm{mg} / \mathrm{L}$ for Cane Branch and $13 \mathrm{mg} / \mathrm{L}$ for Helton Branch in 1974 , because the mineral concentration of precipitation increased about 1.9 times for Cane Branch and 1.6 times for Helton Branch, respectively, as part of the precipitation left the areas by evaporation. These assumptions were based on the relation of runoff to total precipitation for 1974 in the basins: runoff was 53.5 percent for Cane Branch and 64 percent for Helton Branch, by far the maximum annual runoff from each basin for the period of record.
For the purpose of this report, the net dissolvedsolids concentration is defined as the difference between the measured dissolved-solids concentration and the corrected concentration of the precipitation. The net loads of dissolved solids were computed from net concentrations.

During the water years 1957-62, Cane Branch transported a net dissolved load of about 1,370 tons per square mile of drainage area and Helton Branch, a net load of about 111 tons per square mile of drainage area. In water year 1974, the net loads of dissolved solids were 202 tons $/ \mathrm{mi}^{2}$ and 35 tons $/ \mathrm{mi}^{2}$ for Cane Branch and Helton Branch areas, respectively. Thus, the rate of chemical degradation for the Cane Branch area was 


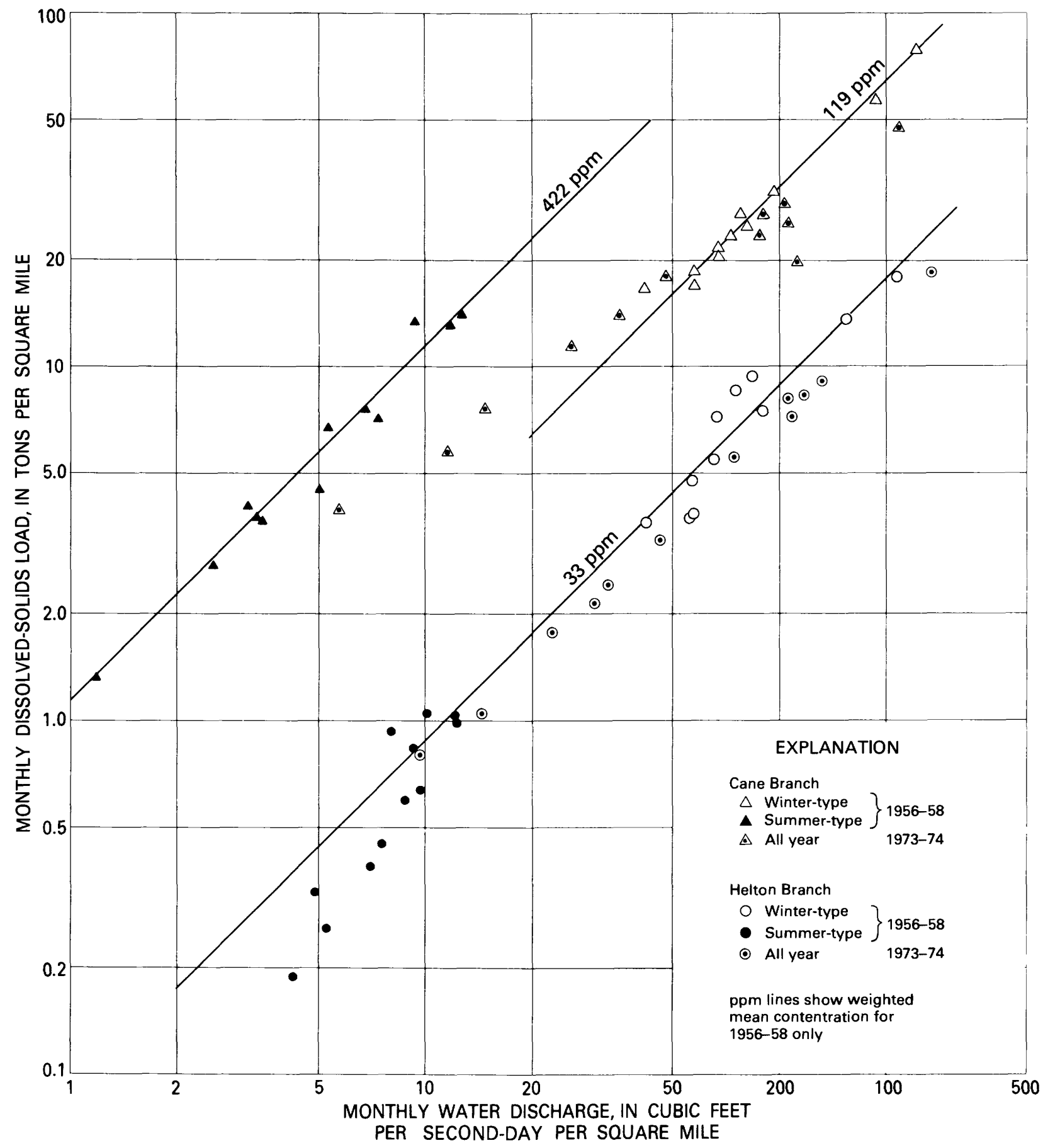

Figure 14.-Relation of monthly water discharge to monthly gross dissolved-solids load in Cane and Helton Branches from October 1956 to September 1958 and from October 1973 to September 1974. 
TABLE 15.-Dissolved solids and sulfate concentrations and loads, Helton Branch at Greenwood, October 1973 to September 1974

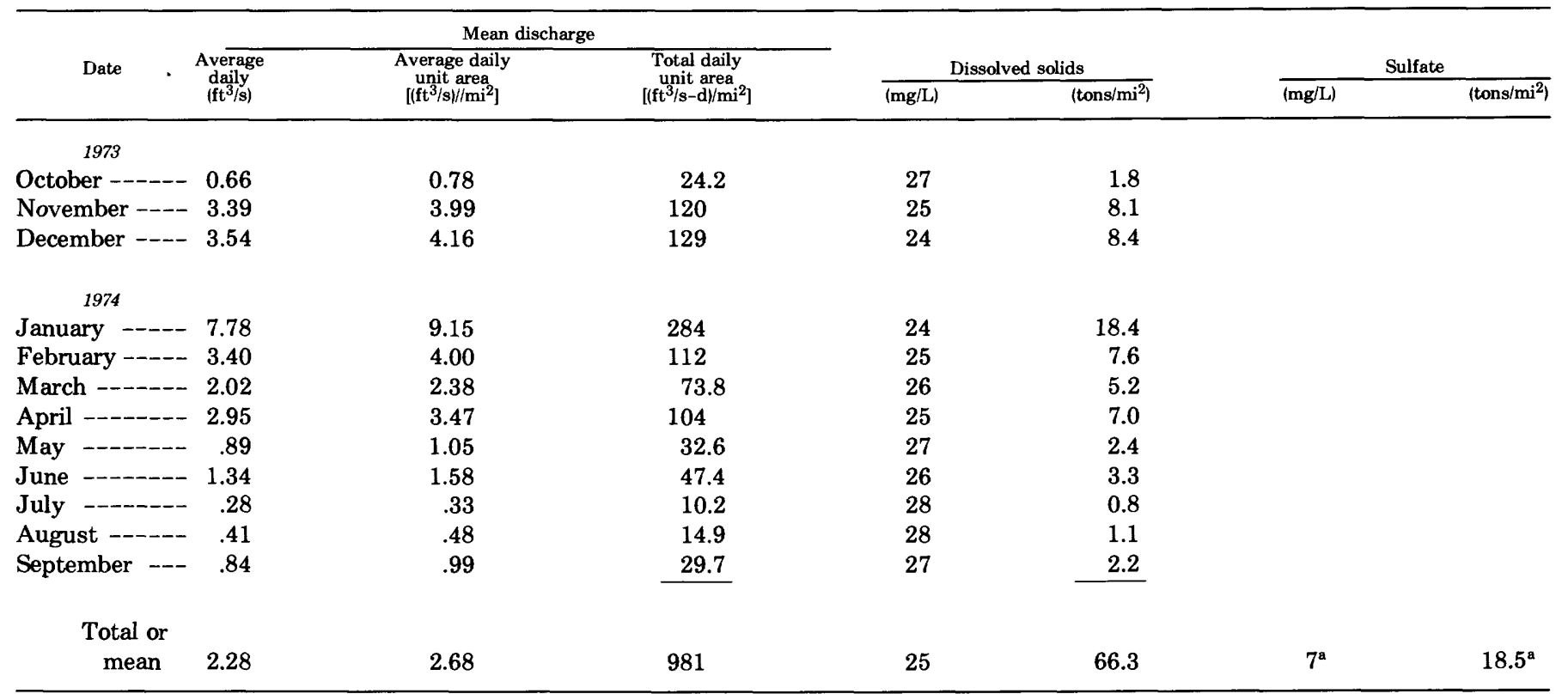

${ }^{\mathrm{a} M e d i a n}$ values.

TABLE 16.-Rates of chemical degradation and runoff in the Cane and Helton Branches study areas, water years 1957-62 and 1974 [e=estimated]

\begin{tabular}{|c|c|c|c|c|}
\hline \multirow[b]{2}{*}{$\begin{array}{l}\text { Water } \\
\text { year }\end{array}$} & \multirow[b]{2}{*}{$\begin{array}{c}\text { Runoff at } \\
\text { gaging station } \\
{\left[\left(\mathrm{ft}^{3} / \mathrm{s}-\mathrm{d}\right) / \mathrm{mi}^{2}\right]}\end{array}$} & \multicolumn{3}{|c|}{$\begin{array}{c}\text { Dissolved solids } \\
\text { (tons per square mile per year) }\end{array}$} \\
\hline & & $\begin{array}{l}\text { Total discharge } \\
\text { at gaging station }\end{array}$ & $\begin{array}{l}\text { Inches } \\
\text { precipitation }\end{array}$ & $\begin{array}{c}\text { Net from } \\
\text { degradation } \\
\text { of the area }\end{array}$ \\
\hline \multicolumn{5}{|c|}{ Cane Branch near Parkers Lake } \\
\hline $1957 \ldots--$ & 580 & 227 & 33 & 194 \\
\hline $1958 \ldots$ & 619 & 219 & 30 & 189 \\
\hline $1959 \ldots$ & 280 & 189 & 24 & 165 \\
\hline $1960 \ldots$ & 691 & 414 & 32 & 382 \\
\hline $1961 \ldots$ & 485 & 221 & 25 & 196 \\
\hline $1962 \ldots$ & 694 & 274 & 33 & 241 \\
\hline $1974 \ldots$ & 842 & 237 & 34 & 202 \\
\hline \multicolumn{5}{|c|}{ Helton Branch at Greenwood } \\
\hline $1957 \ldots$ & 554 & 46 & 32 & 13 \\
\hline 1958 & 607 & 56 & 30 & 26 \\
\hline $1959 \ldots$ & 292 & $25 e$ & 22 & 3 \\
\hline $1960 \ldots$ & 610 & $54 e$ & 30 & 24 \\
\hline $1961 \ldots$ & 478 & $42 e$ & 23 & 19 \\
\hline $1962-\cdots$ & 656 & $58 \mathrm{e}$ & 32 & 26 \\
\hline 1974 & 981 & 66 & 31 & 35 \\
\hline
\end{tabular}

about 12 times greater than that for the Helton Branch area during the 1957-62 water years and about 6 times greater in the wet water year 1974 .

The more rapid rate of chemical degradation in the Cane Branch area is attributed largely to strip mining of coal in 1955-56 and again in 1959, which exposed significant quantities of pyrite and other unweathered minerals to agents of weathering and erosion.

\section{CONCLUSIONS}

Cane Branch became a highly mineralized acidic stream in early 1956 as a result of strip mining of coal in the basin during the period May 1955 to April 1956 and again from December 1958 to August 1959. Concentrations of dissolved solids, sulfate, and acidity in the water of Cane Branch increased significantly after the mining. These concentrations began to decrease in 1960 and by 1962 had reached the 1957 level. Although fluctuations of annual mean concentrations due to climate variations made it difficult to identify a definite trend for the period 1962-66, it appears that there was little change in the rate of chemical weathering or in the chemical composition of the water in Cane Branch during those 5 years of the study. 
The picture that emerges from the water year 1974, even though it was a wet year, is that of a stream and drainage area gradually recovering to their premining quality.

An indication of the quality of the water in the Cane Branch study area prior to the April 1955 mining is given by data for several nearby streams not influenced by mining, which had a median dissolved-solids concentration of $20 \mathrm{mg} / \mathrm{L}$ and a $\mathrm{pH}$ range of 5.2 to 7.6. By June 1956-December 1959 the dissolved-solids concentration of Cane Branch water had risen to a range of 76 to $1,460 \mathrm{mg} / \mathrm{L}$. Sulfate accounted for about 70 percent of the dissolved solids and ranged from 46 to $1,220 \mathrm{mg} / \mathrm{L}$.

In contrast, from August 1967 to October 1974 dissolved solids had narrowed in range from 40 to $366 \mathrm{mg} / \mathrm{L}$ while sulfate ranged from 21 to $226 \mathrm{mg} / \mathrm{L}$.

Helton Branch, which drains a nearby similar basin that has not been mined, changed little in water quality from 1956 to 1974 and remains low in mineral content and with a nearly neutral $\mathrm{pH}$. In the 1973-74 study, the discharged-weighted average concentration of dissolved solids was about $25 \mathrm{mg} / \mathrm{L}$ and the median value for sulfate about $7 \mathrm{mg} / \mathrm{L}$.

Water in pools formed by the strip mining of coal had become less mineralized. Since 1956-59, some pool waters, for example, those in the southwest spoil bank, have shown a tenfold reduction in sulfate concentration and specific conductance and are less acidic. By 1973 , specific conductance of some pool waters had begun to level off at about 100 micromhos, or about that of natural surface-water drainage. The exceptions to large reductions in concentration are the metals aluminum, iron, and manganese which continue, collectively, to exceed $1 \mathrm{mg} / \mathrm{L}$ in acid waters.

Cane Branch in water year 1974 transported out of the basin a dissolved-solids load of 236 tons per square mile, about 57 percent of the load for the high runoff year 1960 and somewhat less than the gross load for water year 1962, also a high runoff year.

Nearby Helton Branch in water year 1974 transported about 66 tons per square mile of dissolvedsolids load. Corrected for the dissolved solids in precipitation during the water years 1957-62, Cane Branch transported a net dissolved-solids load of about 1,370 tons per square mile of drainage area and Helton Branch transported a net load of about 111 tons per square mile of drainage area. In water year 1974 , the net loads of dissolved solids were 202 tons $/ \mathrm{mi}^{2}$ and 35 tons $/ \mathrm{mi}^{2}$ for Cane Branch and Helton Branch areas, respectively. Thus, the rate of chemical degradation was about 12 times greater than that for the Helton Branch area during the 1957-62 water years and about 6 times greater in the wet water year 1974.
The rapid rate of chemical degradation in the Cane Branch area is attributed largely to strip mining of coal in 1955-56 and 1959, which exposed pyrite and other unweathered minerals to agents of weathering and erosion.

\section{EROSION AND DEPOSITION \\ By John A. McCabe \\ U.S. Geological Survey}

\section{INTRODUCTION}

The purpose of a restudy of erosion and deposition in 1974 was to document and evaluate changes in the rate of erosion from the southwest spoil bank and the deposition in the Cane Branch channel during the intervening 8 years. Areas 11 and 12 and gullies 14, 15, 16, and 17 on the southwest spoil bank were resurveyed in February and March 1974. Areas 1 and 2 in the Cane Branch channel were also resurveyed at this time. See figure 15 for the location of these areas and gullies.

\section{EROSION FROM THE SOUTHWEST SPOIL BANK}

Gullies 14 to 17 (see fig. 15) were well incised into the spoil bank at the time of the first survey in August 1959. As the gullies widened and deepened, the cutting action was greater upstream than downstream. Consequently, the channel gradient was reduced, as shown in the following list:

\begin{tabular}{|c|c|c|c|c|}
\hline \multirow{2}{*}{ Period } & \multicolumn{4}{|c|}{ Average gradient of gully- } \\
\hline & 14 & 15 & 16 & 17 \\
\hline August 1959 & 0.389 & 0.251 & 0.344 & 0.367 \\
\hline August 1962 & .382 & .246 & .342 & .336 \\
\hline October 1966 & .368 & .240 & .313 & .302 \\
\hline February-March 1974 & .360 & .230 & .296 & .281 \\
\hline
\end{tabular}

Profiles of gully 14 are shown in figure 16.

Downcutting of the gullies has continued since 1966 but at a decreasing rate. The following tabulation shows the total degradation for the periods and the average degradation per year of each gully.

\begin{tabular}{|c|c|c|c|c|}
\hline \multirow{2}{*}{ Period } & \multicolumn{4}{|c|}{ Mean degradation along profile, in feet, of gully } \\
\hline & 14 & 15 & 16 & 17 \\
\hline 1959-62-- & 1.17 & 1.51 & 1.88 & 1.48 \\
\hline per year -...- & .39 & .50 & .63 & .49 \\
\hline $1962-66$ & 1.12 & 2.32 & 1.02 & 1.86 \\
\hline per year - - & .28 & .58 & .26 & .46 \\
\hline $1966-74-$ & 1.92 & 1.88 & .36 & .48 \\
\hline per year - & .24 & .24 & .05 & .06 \\
\hline
\end{tabular}

Two small areas, 11 and 12, on top of the southwest spoil bank, were resurveyed in February and March 1974. Area 11 drains into one large gully. A contour map of area 11, as surveyed in 1974, is shown in figure 17. 


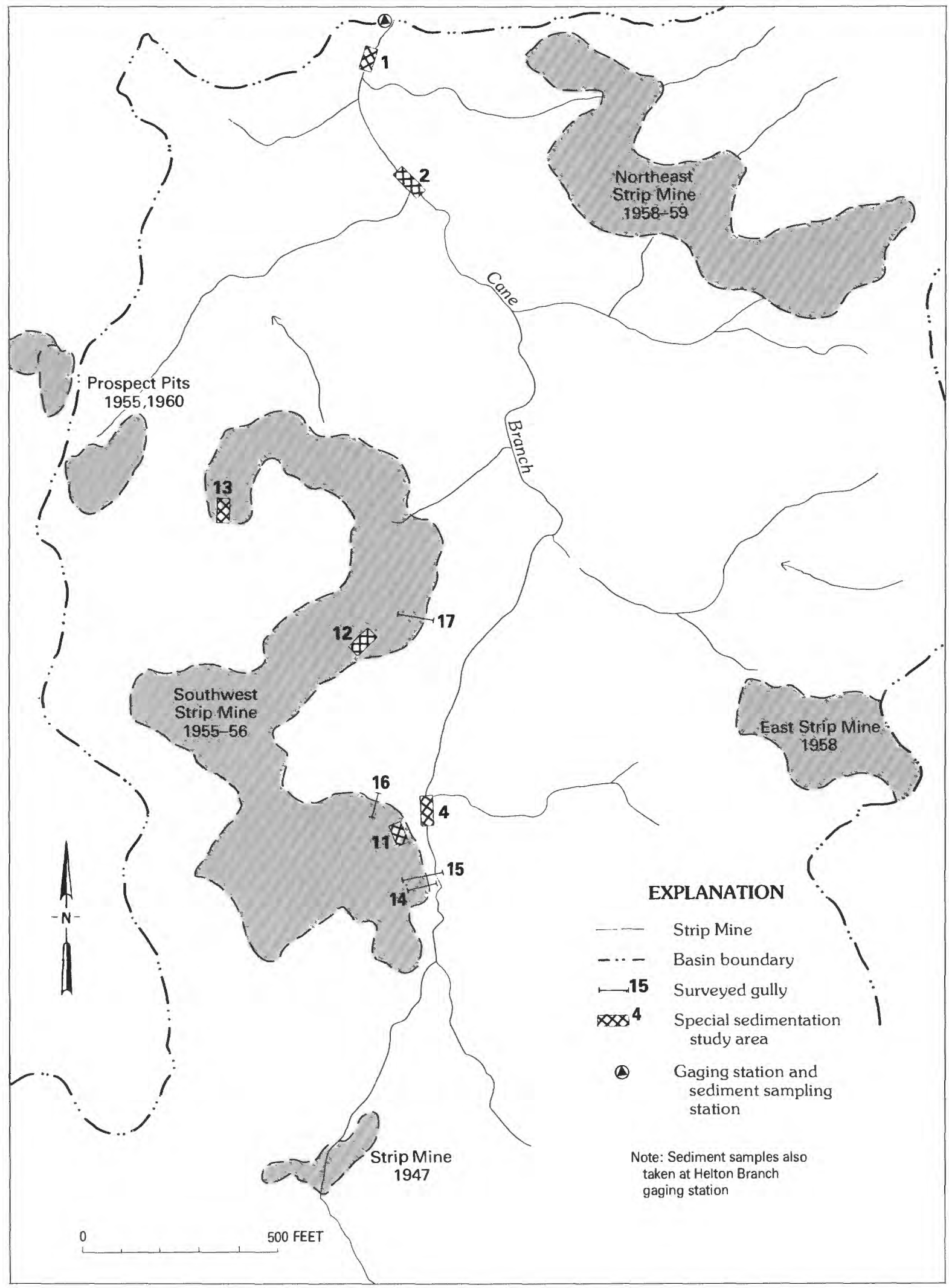

Figure 15.-Sediment sampling and study sites in the Cane Branch study area, 1973-74. 


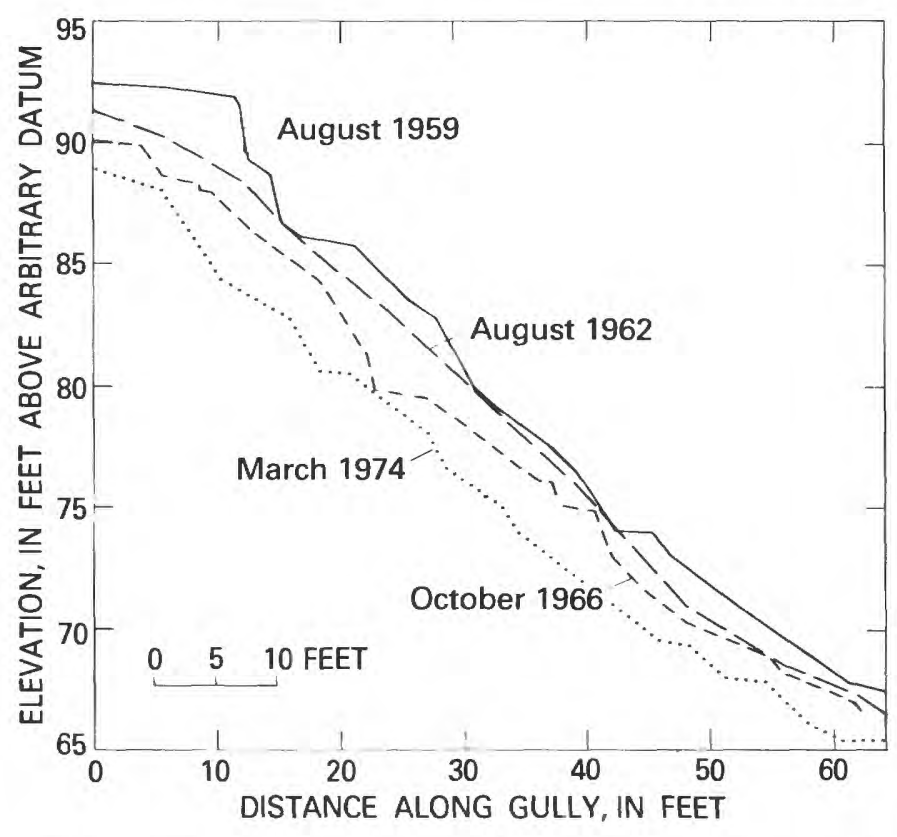

Figure 16.-Profiles of the floor of gully 14 showing erosion from - August 1959 to March 1974.

In area 11 , erosion was most noticeable along the main gully. The profiles shown in figure 18 illustrate the changes of section $A-A^{\prime}$ between October 1958 and March 1974. From October 1966 to March 1974 the top of the spoil bank was lowered less than $0.2 \mathrm{ft}$ by sheet erosion. During the same period, erosion from the gully part of the area (northeast) averaged about $2 \mathrm{ft}$.

Channel development in the spoil bank in area 11 is shown in the photographs in figure 19, and gully development is shown in the photographs in figure 20.

Area 12 (fig. 15) is a rilled and terraced part of the southwest spoil bank (see fig. 21). The 1974 survey indicated an average net fill on the area of less than $0.1 \mathrm{ft}$ since the 1966 survey, well within the margin of measurement error. A comparison of the two surveys indicates a movement of material from the edge of the top of the spoil bank to the toe of the bank.

Surveys of the two areas indicate greater losses from a single developing gully that drains a larger area, such as in figure 18, than from the development of many small gullies.

\section{SEDIMENT DEPOSITION \\ IN CANE BRANCH}

Areas 1 and 2 (see fig. 15), reaches of Cane Branch, were resurveyed in February 1974. The 1974 topographic survey of area 1 is shown in figure 22, and longitudinal and cross-section profiles are shown in figure 23 .
The October 1966 survey indicated that the channel has silted up since the 1958 and 1962 surveys. However, the February 1974 survey showed that the channel through area 1 has been scoured and the brush dam removed. It now approximates the channel surveyed in 1958 and 1962. Whether this has been a gradual change since 1966 or has happened in one or more stages is not known. Also, the channel may have experienced a number of scour-and-fill cycles since 1966 . The channel appears to be returning to its condition prior to strip mining. Material eroded from the spoil piles and deposited in the channel from 1958 to 1966 has been removed and transported farther downstream.

Comparative photographs of the Cane Branch channel in area 1 are shown in figure 24. The straight tree with the light-colored trunk in the 1958 and 1966 photographs on the left bank had been removed prior to the 1974 photograph.

Water discharges at the times of these photographs were $0.53 \mathrm{ft}^{3} / \mathrm{s}$ on April 20,1958, $0.11 \mathrm{ft}^{3} / \mathrm{s}$ on October 26, 1966, and $5.4 \mathrm{ft}^{3} / \mathrm{s}$ on April 2, 1974.

Area 2 was also resurveyed in February 1974 (see fig. 25). It had not been surveyed in 1966 , but a comparison of the profiles of the 1958,1962 , and 1974 surveys showed very little difference among the three. If surveyed in 1966, the channel might have been found to be filled compared with the other surveys, but this is speculation. The channel of Cane Branch probably alternatively scours and fills, depending on the distribution of streamflow.

\section{EROSION AND SEDIMENT YIELD \\ By Beecher J. Hines \\ U.S. Soil Conservation Service}

Gross-erosion and sediment-yield predictions were made for Cane Branch, West Fork of Cane Branch, and Helton Branch. The universal soil-loss equation (USLE) developed through cooperative efforts of the Agricultural Research Service, State Experiment Stations, and the Soil Conservation Service requires consideration of soil, topographic, rainfall, and cover factors.

The USLE is

$$
A=R K L S C P
$$

where

$A$ is the average annual soil loss, in tons per acre;

$R$ is the rainfall factor, the number of erosion-index units in a normal year's rain.

$K$ is a measure of the rate at which soil will erode, expressed as the soil loss per acre per unit of $R$ on a 


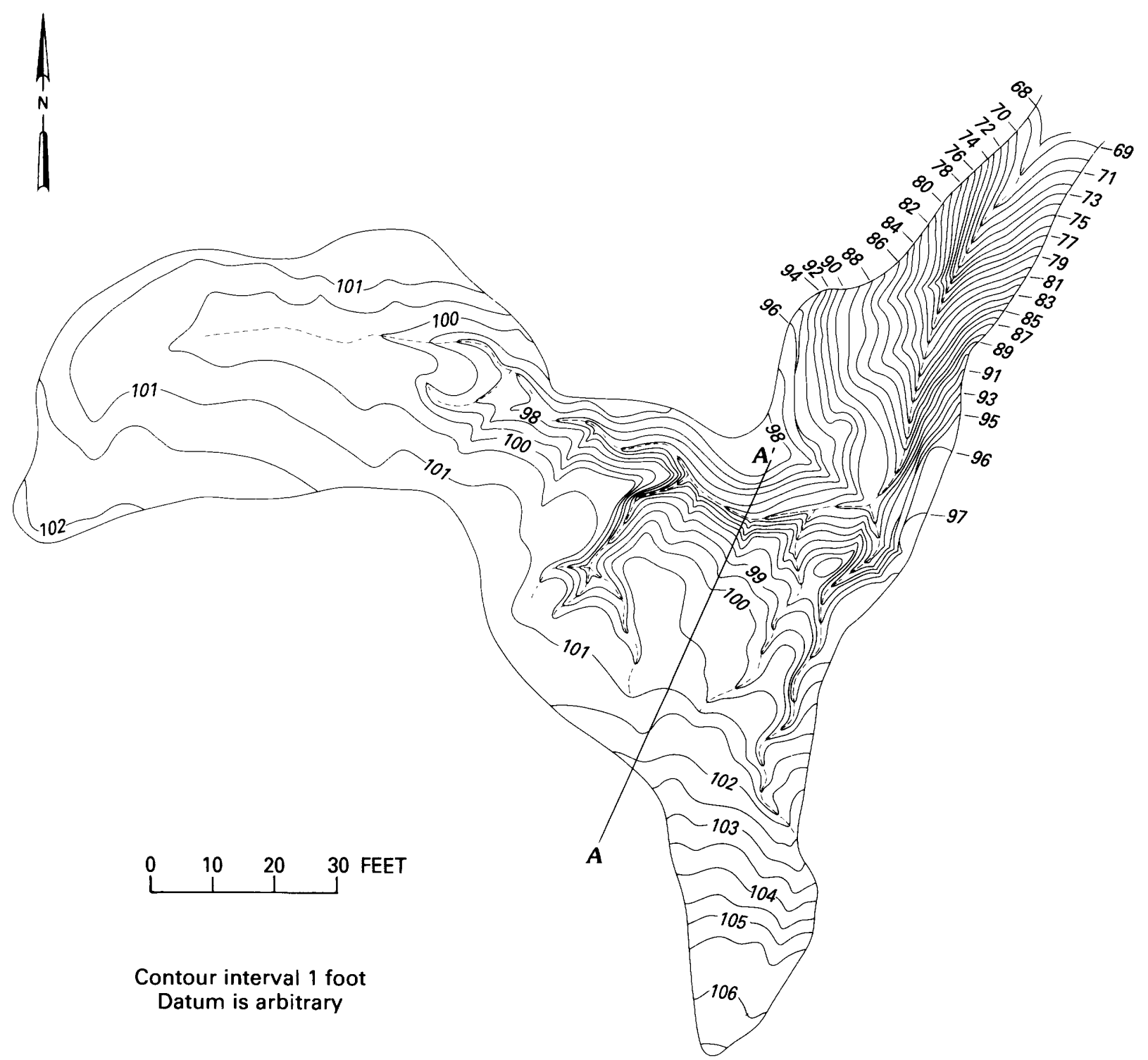

FIGURE 17.-Contour map of area 11, an area on the southwest spoil bank drained by a large gully, February to March 1974.

cultivated, continuous-fallow, 9-percent slope $72.6 \mathrm{ft}$ long. Different kinds of soil erode at different rates.

$L$ is the length-of-slope factor. Slope length is defined as the distance from the point of origin of overland flow to either of the following, whichever is limiting for the major portion of the area under consideration: (1) the point where the slope decreases to the extent that deposition begins, or (2) the point where runoff enters a well-defined chan- nel which may be part of a drainage network or a constructed channel such as a terrace or diversion.

$S$ is the steepness-of-slope factor, the ratio of soil loss from the field gradient to that from a 9-percent slope.

$C$ is the cover factor, the expected ratio of soil loss from land used under specified cover conditions to corresponding soil loss from continuous bare fallow under the same soil, slope, and rainfall conditions. 


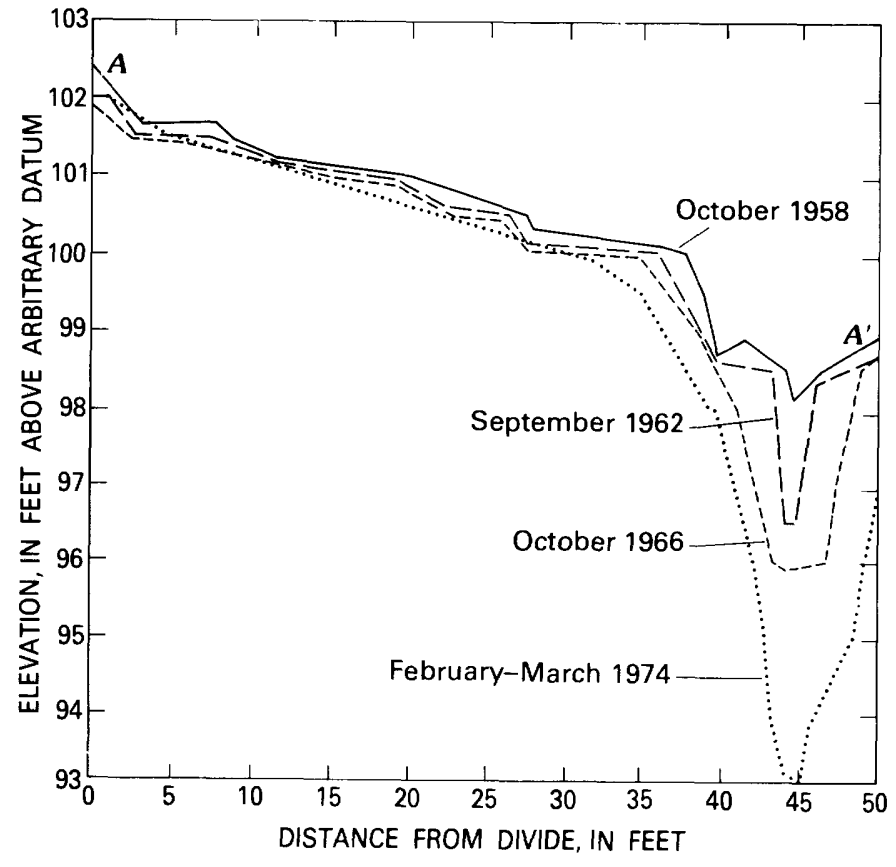

FIGURE 18.-Profiles of upper surface of spoil bank, area 11, section $A-A^{\prime}$ showing erosion from October 1958 to March 1974.

$P$ is the erosion-control-practice factor, the ratio of soil loss with a specified practice to soil loss occurring from uphill and downhill field operations when soil, slope, and rainfall remain equal. (The practice factor is applicable only on cropland.)

Soils information was developed by A. S. Johnson and J. W. Roehl in 1959 (Musser, 1963, table 1) and was kept current by J. W. Roehl, A. S. Johnson, C. R. Collier, and others (Collier and others, 1964, 1970).

Sediment-delivery ratios are the ratios, expressed in percentages of sediment yields at a specified location to the gross erosion of the watershed or subwatershed unit.

The total suspended sediment yield for Cane Branch, as shown in table 17 , is the measured cumulative annual yield of 784 tons per year to the Cane Branch gaging station in the 1974 water year. To determine an average sediment-delivery ratio, the magnitude of the suspended sediment yield and the total amount of erosion must be known. For Cane Branch, the gross erosion in the 1974 water year was 1,604 tons per year and the suspended sediment yield was 784 tons per year $\left[1,170\left(\right.\right.$ tons $\left.\left./ \mathrm{mi}^{2}\right) / \mathrm{yr}\right]$. The sediment-delivery ratio is then $784 / 1,604$, or 49 percent. See tables 18 and 19 for similar data for Helton and West Fork Cane Branches. Sediment-delivery ratios for Helton Branch were based primarily on sediment-yield data collected before 1964 (see Collier and others, 1964, p. B53). Present land use and cover conditions were used in computing current gross erosion.
TABLE 17.-Gross erosion and average annual sediment yield for Cane Branch basin, 1974 water year

[Basin area, 0.67 square mile]

\begin{tabular}{|c|c|c|c|c|}
\hline Acres & $\begin{array}{c}\text { Soil loss } \\
\text { (tons per acre) }\end{array}$ & $\begin{array}{c}\text { Total } \\
\text { soil loss } \\
\text { (tons) }\end{array}$ & $\begin{array}{c}\text { Delivery } \\
\text { ratio } \\
\text { (percent) }\end{array}$ & $\begin{array}{c}\text { Suspended } \\
\text { sediment } \\
\text { yield } \\
\text { (tons) }\end{array}$ \\
\hline Idle ------- 24.7 & 0.48 & 12 & 16 & 19.2 \\
\hline Woodland $\cdots-360.8$ & .25 & 92 & 16 & 14.7 \\
\hline Mine spoil --- 43.1 & 34.80 & 1,500 & 50 & 750.0 \\
\hline Total ----- 428.6 & & 1,604 & & 784 \\
\hline \multicolumn{5}{|c|}{ Annual gross erosion (tons per square } \\
\hline Delivery ratio (percent) & $---\infty-\infty--$ & 49.0 & -- & --- \\
\hline
\end{tabular}

TABLE 18.-Gross erosion and average annual sediment yield for Helton Branch basin

[Basin area, 0.85 square mile]

\begin{tabular}{|c|c|c|c|c|c|}
\hline & Acres & $\begin{array}{c}\text { Soil loss } \\
\text { (tons per acre) }\end{array}$ & $\begin{array}{l}\text { Total } \\
\text { soil loss } \\
\text { (tons) }\end{array}$ & $\begin{array}{c}\text { Delivery } \\
\text { ratio } \\
\text { (percent) }\end{array}$ & $\begin{array}{l}\text { Suspended } \\
\text { sediment } \\
\text { yield } \\
\text { (tons) }\end{array}$ \\
\hline Idle --------- & 11.8 & 0.42 & 5 & 10 & 0 \\
\hline Pasture -- - - - & 32.3 & .06 & 2 & 10 & 0 \\
\hline Woodland -- - & 494.9 & .58 & 286 & 10 & 29 \\
\hline Urbanizing ---- & 2.0 & 100.00 & 200 & 10 & 20 \\
\hline Roadbank --- - & 1.6 & 300.00 & 180 & 70 & 126 \\
\hline Total -- - - & 541.0 & & 673 & & 175 \\
\hline
\end{tabular}

Annual gross erosion (tons per square mile) - - -

Delivery ratio (percent) - -

Sub-watershed delivery ratio (percent) --- 26

${ }^{1}$ Roadbank units shown under acres are bank miles.

TABLE 19.-Gross erosion and average annual sediment yield for West Fork Cane Branch basin [Basin area, 0.26 square mile]

\begin{tabular}{|c|c|c|c|c|}
\hline Acres & $\begin{array}{c}\text { Soil loss } \\
\text { (tons per acre) }\end{array}$ & $\begin{array}{l}\text { Total } \\
\text { soil loss } \\
\text { (tons) }\end{array}$ & $\begin{array}{c}\text { Delivery } \\
\text { ratio } \\
\text { (percent) }\end{array}$ & $\begin{array}{c}\text { Suspended } \\
\text { sediment } \\
\text { yield } \\
\text { (tons) }\end{array}$ \\
\hline Idle --_-_-- $\quad 0.3$ & 0.10 & 0 & 10 & 0 \\
\hline Woodland -- --162.0 & .26 & 42 & 10 & 4 \\
\hline Mine Spoil ---- & 34.00 & 102 & 50 & 50 \\
\hline Total -- - 165.3 & & 244 & & 54 \\
\hline \multicolumn{2}{|c|}{$\begin{array}{l}\text { Annual gross erosion (tons per square } \\
\text { mile) }\end{array}$} & 554 & -- & 208 \\
\hline \multirow{2}{*}{\multicolumn{2}{|c|}{$\begin{array}{l}\text { Delivery ratio (percent) - } \\
\text { Sub-watershed delivery ratio } \\
\text { (percent) }\end{array}$}} & 38 & -- & --- \\
\hline & & 38 & -- & --- \\
\hline
\end{tabular}




\section{A}

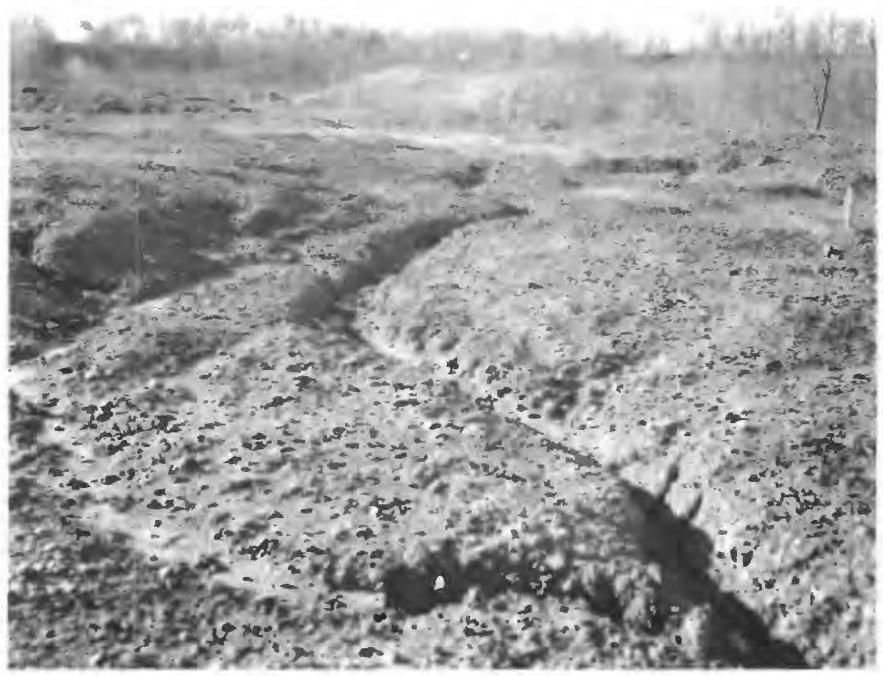

$\boldsymbol{B}$

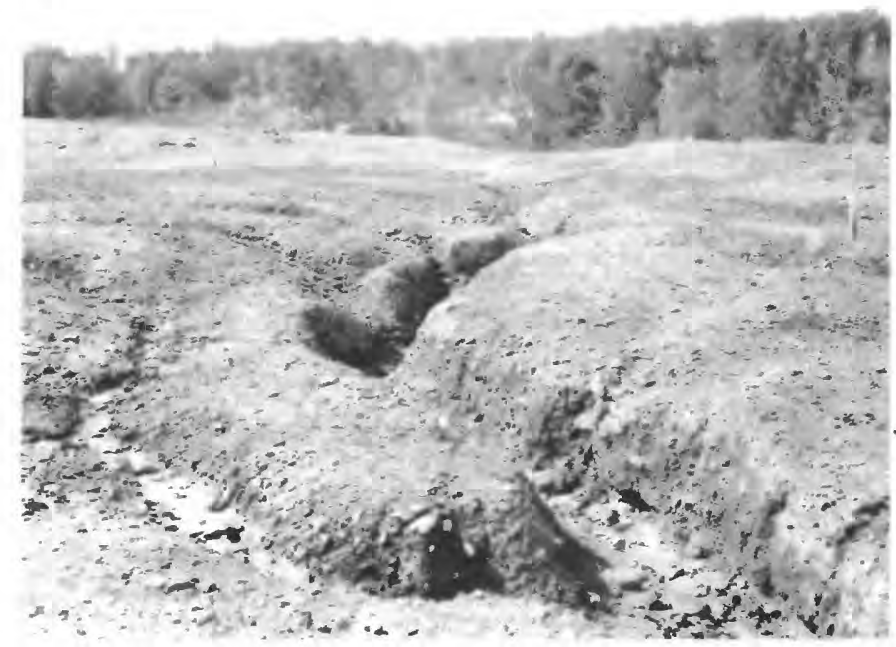

C

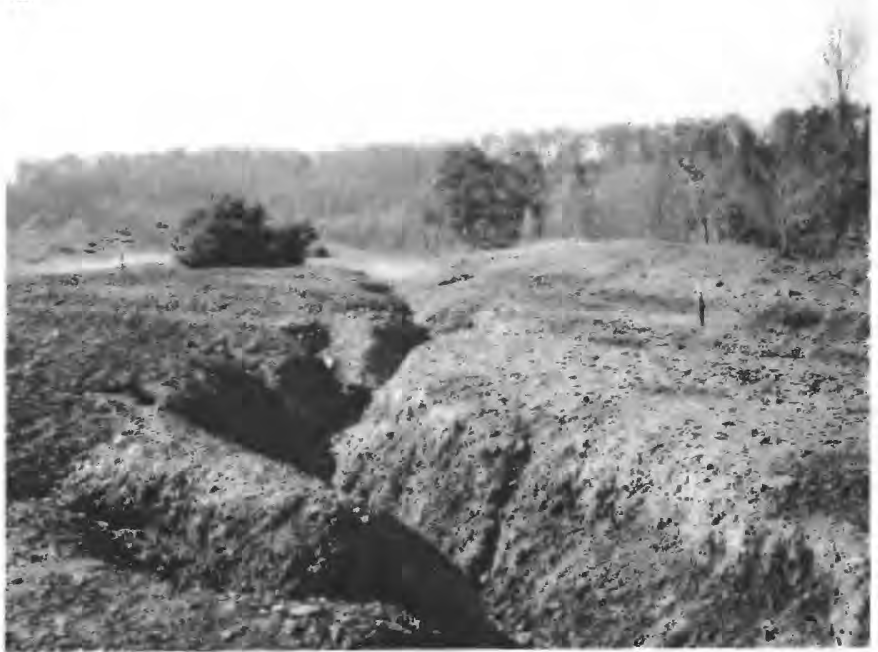

D

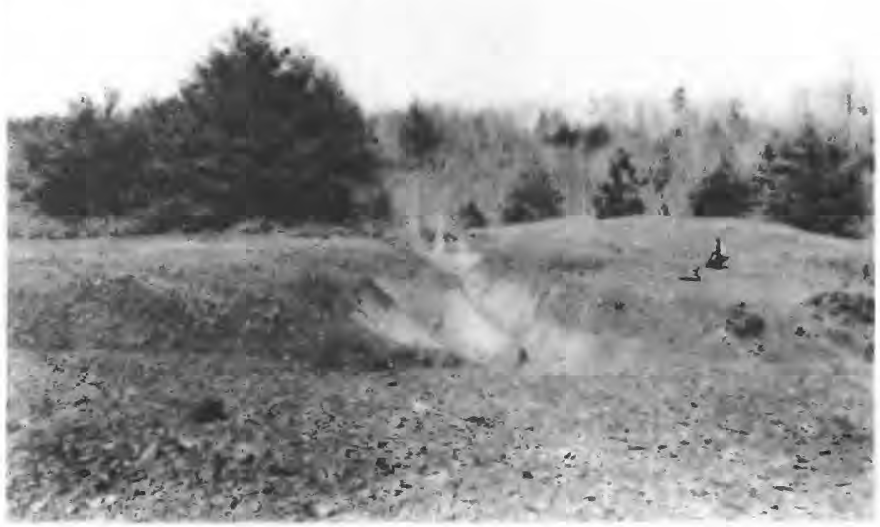

FIGURE 19.-Comparative photographs showing channel development of upper surface of spoil bank, area 11. Photographed $(A)$ December 10, 1958, (B) September 30, 1962, (C) October 20, 1966, and $(D)$ April 2, 1974.

\section{CONCLUSIONS}

Erosion is still occurring on the southwest spoil bank. Resurveys of two small areas and several gullies indicate that most of this erosion is in gullies rather than on the top of the spoil bank.

Annual gross erosion in the 0.67-square-mile Cane Branch study area is about 2,400 tons $/ \mathrm{mi}^{2}$ and the annual measured suspended sediment yield at the gaging station is 1,170 tons $/ \mathrm{mi}^{2}$. Thus, about 49 percent of the sediment eroded is delivered to the streams. The bulk of the soil loss, 1,500 tons, or nearly 94 percent, comes from the spoil piles, which account for 10 percent of the basin area.

These observations are in sharp contrast with the undisturbed (unmined) Helton Branch basin, where the annual gross erosion is about 796 tons $/ \mathrm{mi}^{2}$ and the sediment yield is about 207 tons $/ \mathrm{mi}^{2}$.

Thus, Cane Branch is eroding at 3 times and sediment yield is more than 5 times the rate observed for Helton Branch.

With only about 2 percent of West Fork Cane Branch acreage in mine spoil, there is no apparent increase in erosion or sediment yield in comparison with values compiled for Helton Branch basin. 

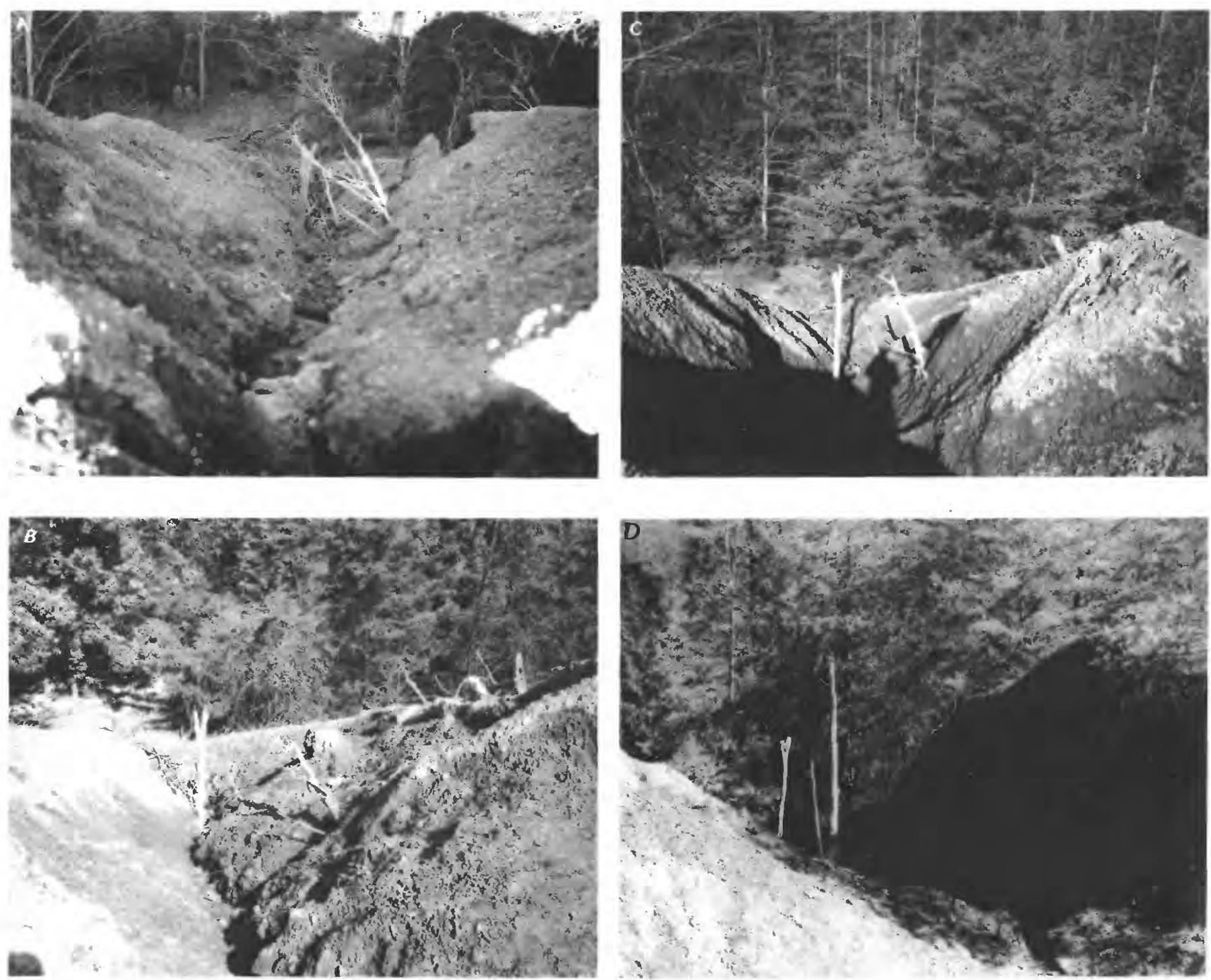

FiguRE 20.-Comparative photographs showing gully development in area 11 . Photographed $(A)$ December $10,1958,(B)$ September 30,1962 , (C) October 20, 1966, and (D) April 2, 1974.

\section{SUSPENDED-SEDIMENT TRANSPORT}

By John F. Santos

U.S. Geological Survey

\section{SUSPENDED-SEDIMENT TRANSPORT AT}

CANE BRANCH GAGING STATION

Two previous studies of suspended-sediment yields (Collier and others, 1964, 1970) were based on a comparison of suspended-sediment yield from Cane Branch (strip mined) basin to that of Helton Branch (undisturbed) basin. The present study (1974) was made to identify the changes in suspended-sediment yields, if any, that have taken place in Cane Branch since mining stopped in 1959. No samples or data were collected from Helton Branch. It is assumed that since no development of any consequence had occurred in Helton Granch basin, the suspended-sediment yield would be the same as before.

The relation of suspended-sediment concentration to precipitation and water discharge for an individual storm is shown in figure 26. Comparison with previous data of Collier (in Collier and others, 1970, p. C39) shows that this relation has not changed appreciably. Peak suspended-sediment discharge generally occurs at, or slightly before, peak water discharge.

The annual suspended-sediment yield from Cane Branch ranged from 617 to 3,010 tons $/ \mathrm{mi}^{2}$ during 1957-66 (table 20). The greatest weighted mean con- 


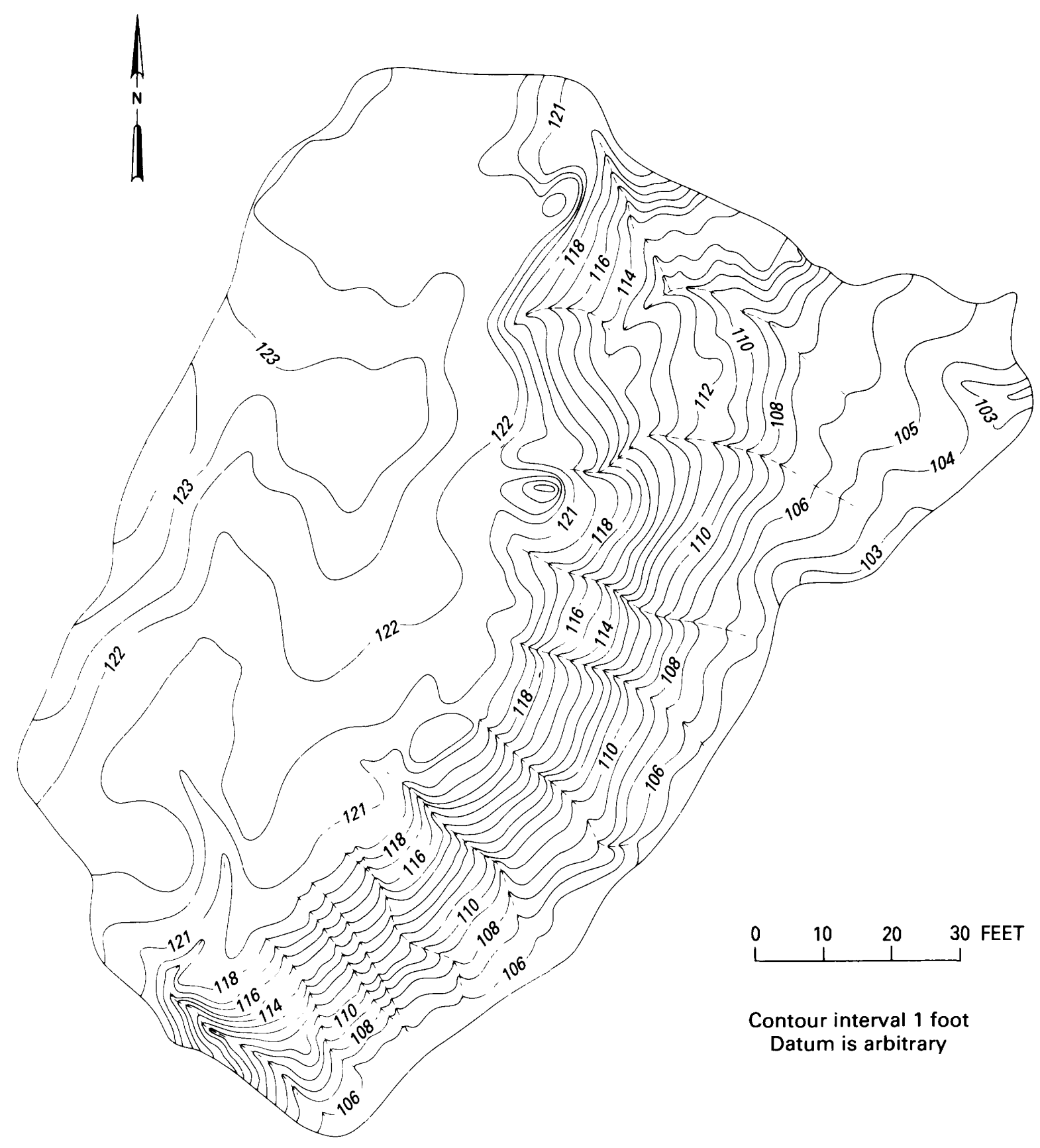

FIGURE 21.-Area 12, a rilled and terraced part of the southwest spoil bank, February 1974.

centration was $1,640 \mathrm{mg} / \mathrm{L}$. In 1974 the suspended- For the combined periods 1957-62 and 1965-66, the sediment yield was 1,170 tons $/ \mathrm{mi}^{2}$ with a weighted average annual-water discharge was $332\left(\mathrm{ft}^{3} / \mathrm{s}\right) / \mathrm{d}$ with mean concentration of $416 \mathrm{mg} / \mathrm{L}$. This weighted mean an average annual suspended-sediment yield of concentration is the smallest for the period of record $1,614 \mathrm{tons} / \mathrm{mi}^{2}$. Apparently, the suspended-sediment even though water discharge was 21 percent more than yield from Cane Branch has decreased since the prethe previous highest annual-water discharge (1962). vious studies. 


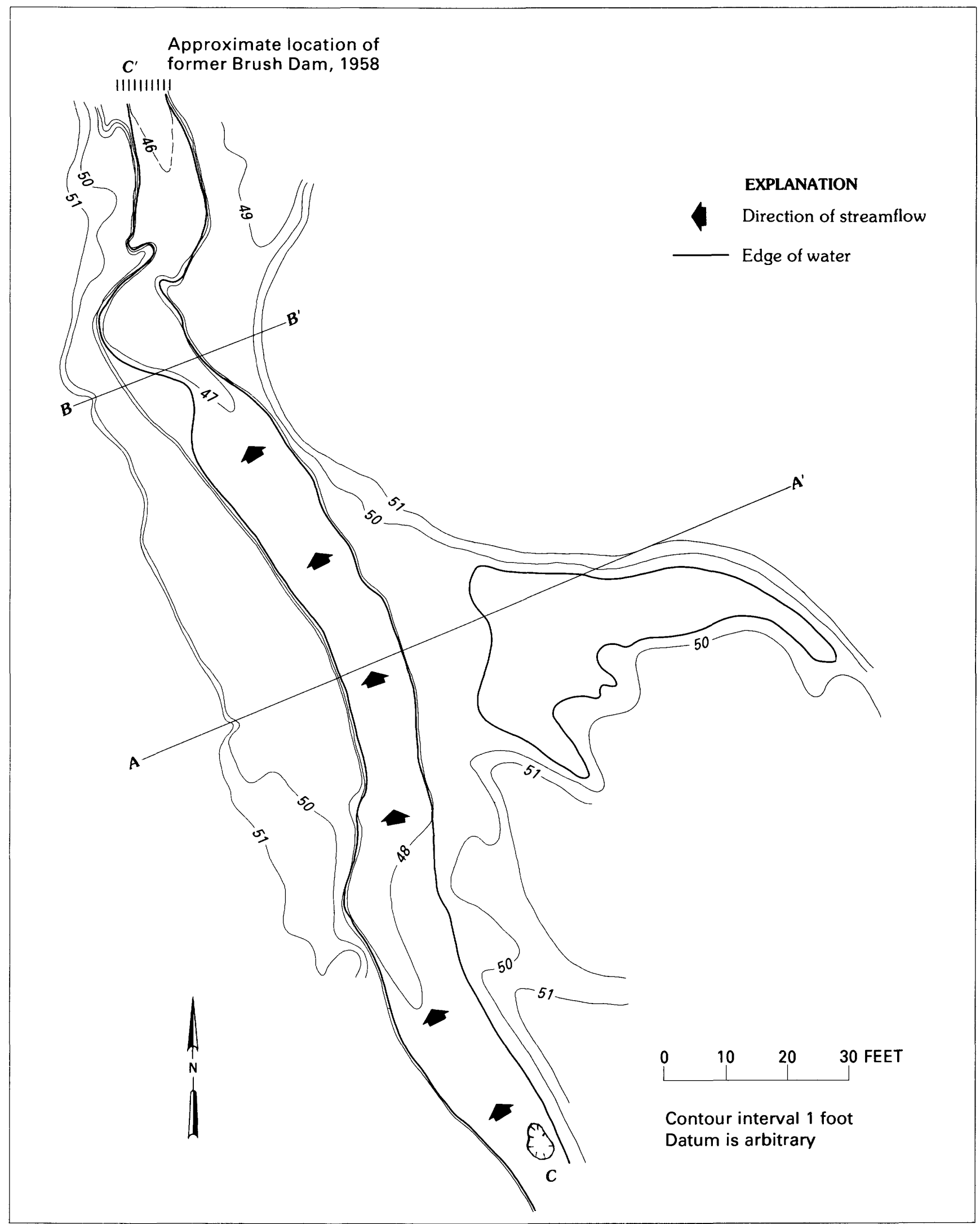

Figure 22.-Area 1, a reach of Cane Branch channel, February 1974. 

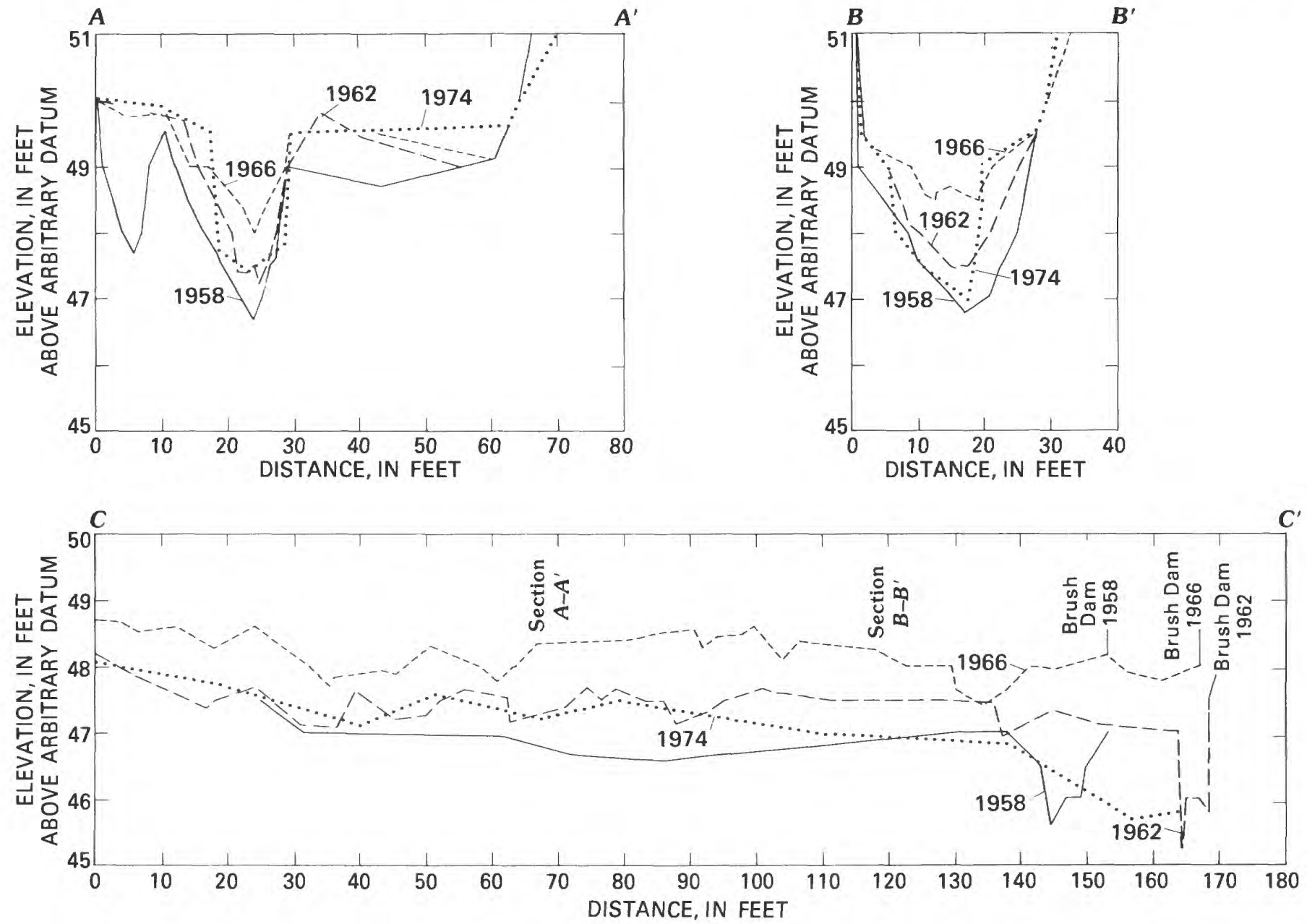

FIGURE 23.-Cross-section and longitudinal profiles of Cane Branch in area 1.

TABLE 20.-Summary of sediment discharge by water year, Cane Branch near Parkers Lake

\begin{tabular}{|c|c|c|c|c|c|}
\hline Water year & $\begin{array}{c}\text { Water } \\
\text { discharge } \\
\left(\mathrm{ft}^{3} / \mathrm{s}-\mathrm{d}\right)\end{array}$ & $\begin{array}{l}\text { Water discharge } \\
\text { as a percentage of } \\
\text { 1974 water discharge }\end{array}$ & $\begin{array}{l}\text { Suspended- } \\
\text { sediment } \\
\text { concentration } \\
(\mathrm{mg} / \mathrm{L})^{1}\end{array}$ & $\begin{array}{l}\text { Suspended- } \\
\text { sediment } \\
\text { discharge } \\
\text { (tons) }\end{array}$ & $\begin{array}{c}\text { Suspended- } \\
\text { sediment } \\
\text { yield } \\
\text { (tons } / \mathrm{mi}^{2} \text { ) }\end{array}$ \\
\hline $1956^{2}$ & 333 & - & 437 & 394 & 588 \\
\hline 1957 & 389 & 69 & 537 & 563 & 840 \\
\hline 1958 & 415 & 73 & 1,160 & 1,295 & 1,930 \\
\hline 1959 & 188 & 33 & 1,640 & 831 & 1,240 \\
\hline 1960 & 464 & 82 & 1,380 & 1,731 & 2,580 \\
\hline 1961 & 325 & 56 & 689 & 604 & 901 \\
\hline 1962 & 464 & 82 & 1,600 & 2,018 & 3,010 \\
\hline 1963 & 266 & -- & $\ldots--$ & --- & $-\cdots$ \\
\hline 1964 & 190 & -- & -.-- & ---- & $-\cdots$ \\
\hline $1964^{3} \ldots$ & 28 & -- & 2,510 & 192 & 286 \\
\hline 1965 & 286 & 51 & 1,550 & 1,200 & 1,790 \\
\hline 1966 & 121 & 21 & 1,270 & 413 & 617 \\
\hline 1974 & 565 & -- & 416 & 784 & 1,170 \\
\hline
\end{tabular}



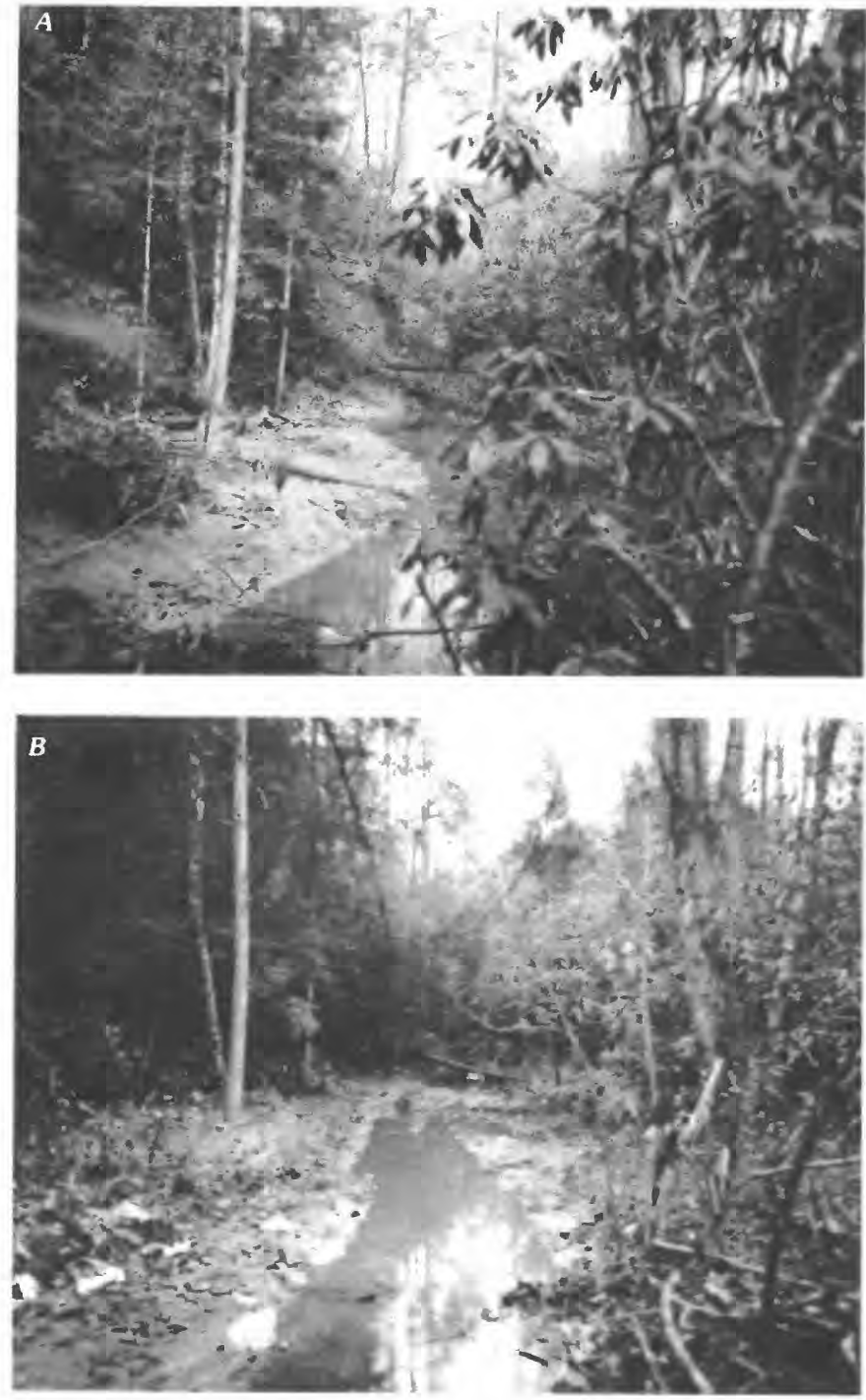

Figure 24.-Comparative photographs of the Cane Branch channel in area 1. Photographed (A) April 20, 1958, (B) October 26, 1966, and (C) April 2, 1974.

Figure 27 shows how the suspended-sediment discharge and water discharge varied for the period of record, and table 21 summaries the 1974 water year data.

\section{STORMS}

Collier and Musser (in Collier and others, 1964, p. B58) and Collier (in Collier and others, 1970, p. C40) used precipitation and water discharge to characterize two types of suspended-sediment discharge. They called them winter-type and summer-type storms. The summer-type storms are characterized by intense rainfall of short duration that produces a rapid rise and fall in water discharge (fig. 26). The winter-type storms are produced by rainfall of lesser intensity and longer

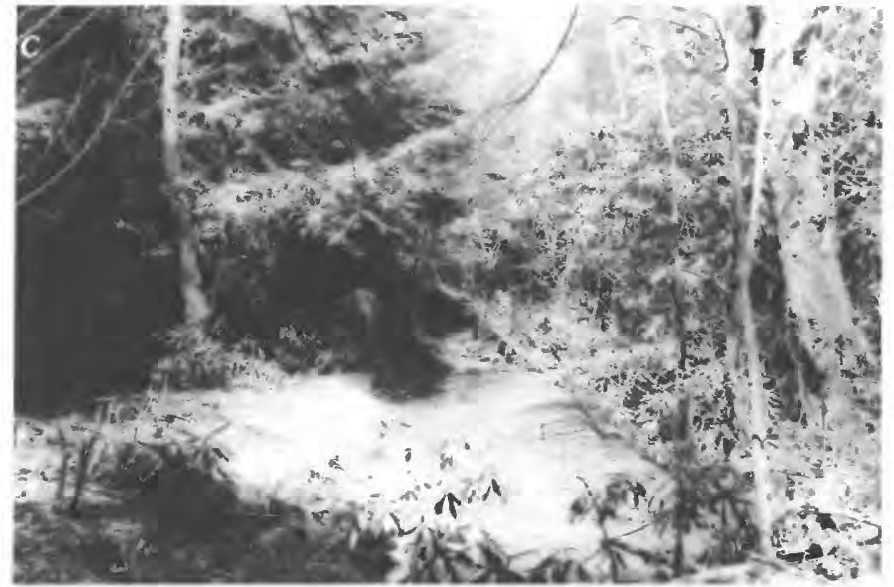

duration that produces a more gradual rise in water discharge followed by a gradual decrease in water discharge (fig. 28). As in the previous studies (Collier and others, 1964, p. B58), the part of water discharge considered to be base flow was subtracted from the total flow of each storm. The suspended-sediment discharge attributable to base flow was estimated to be negligible. Figure 29 compares $1956-59$ storm data with 1973-74 data for Cane Branch (see also Collier and others, 1964, fig. 39, p. B59). In 1973-74 there was much greater variability in sediment yield than there was during the earlier period. For the earlier years, only one summer-type storm plotted in the area of winter-type storms, but some winter-type storms plotted with the summer-type storms. During 1973-74, the type of storm had less influence on the sediment yield, and the resulting data points were intermingled for the two types of storms. This shows that for some of the intense, summer-type storms the amount of sediment available for transport was not as large as in the past.

\section{CONCLUSIONS}

The present data (1973-74) support the conclusion that sufficient revegetation has taken place in the Cane Branch study area to cause a significant decrease in suspended-sediment yields. The discharge-weighted concentration of suspended sediment in the 1974 water year was the minimum for the study years while the water discharge was a maximum. This significant change in water discharge versus sediment indicates that there is less material readily available for transport out of the basin. Although Cane Branch shows some sign of recovery toward the natural sediment discharge characteristics of Helton Branch, it will be many years, if ever, before the two basins are equivalent in sediment discharge. A practical and acceptable similarity can be reached much sooner if no more mining, farming, or other land-use change occurs. 


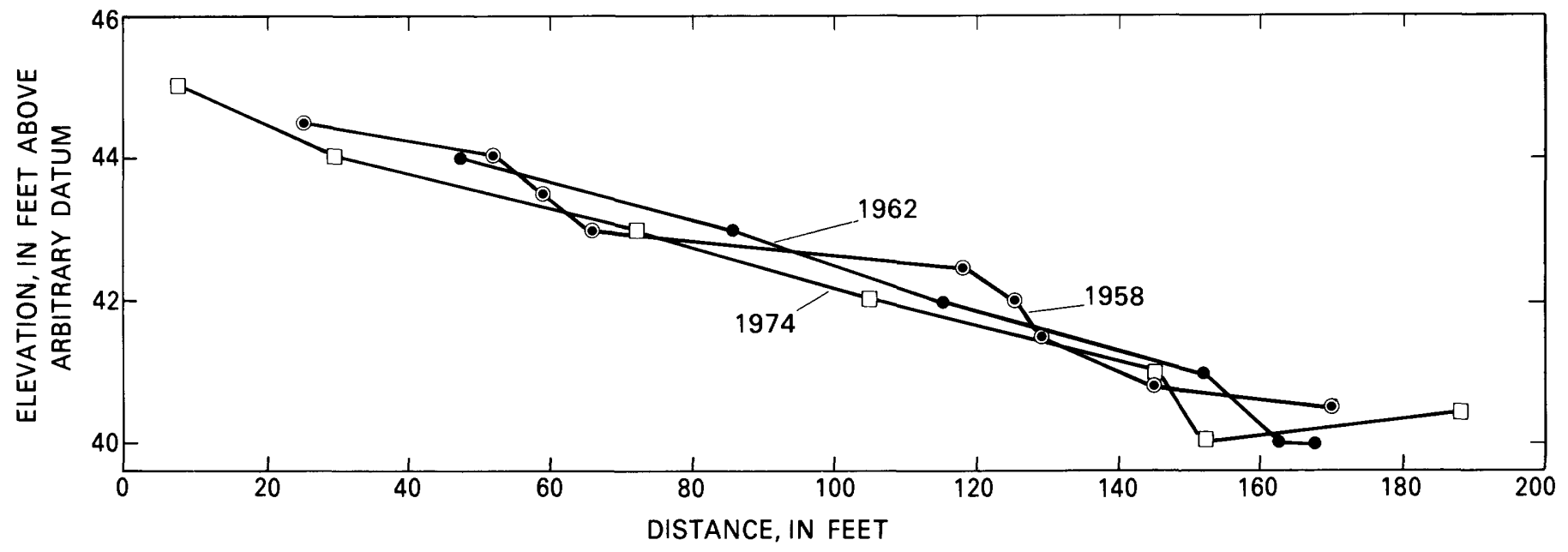

Figure 25.-Longitudinal profile of Cane Branch in area 2.
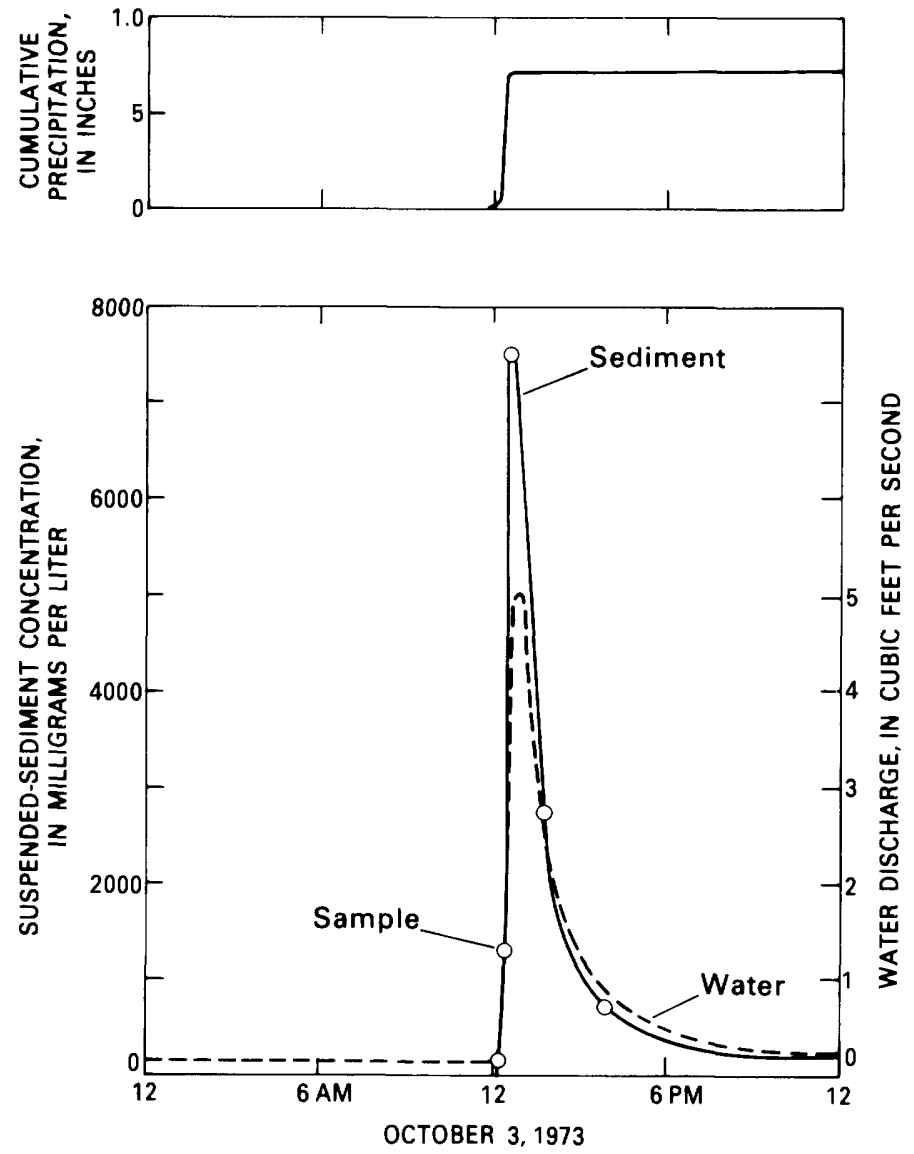

FIGURE 26.-Relation of suspended-sediment concentration to precipitation and water discharge, Cane Branch near Parkers Lake, October 3, 1973.

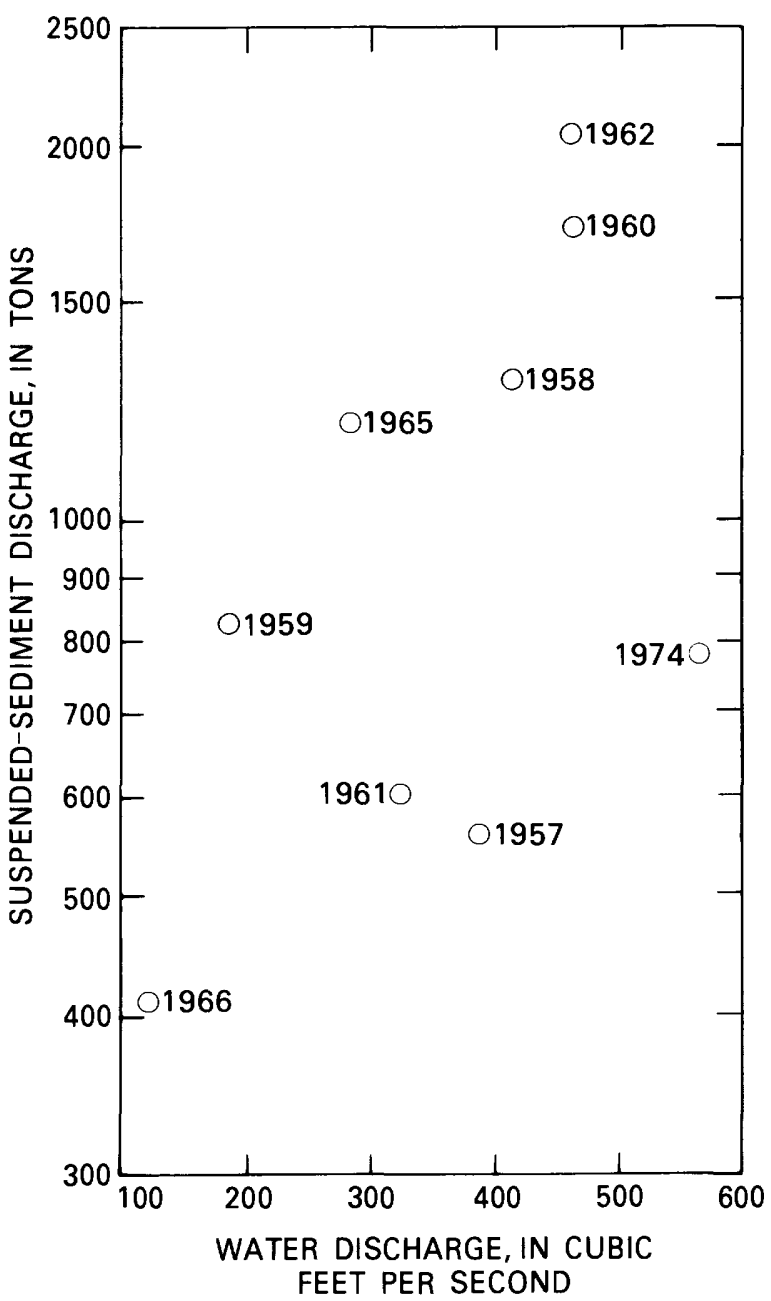

FIGURE 27.-Variation in suspended-sediment discharge and water discharge, Cane Branch and Parkers Lake, by water year. 
TABLE 21.-Summary of suspended sediment discharge by month, Cane Branch near Parkers Lake

\begin{tabular}{|c|c|c|c|}
\hline $\begin{array}{l}\text { Year and } \\
\text { month }\end{array}$ & $\begin{array}{c}\text { Water } \\
\text { discharge } \\
\left(\mathbf{f t} \mathbf{t}^{3 / s}-\mathbf{d}\right)\end{array}$ & $\begin{array}{c}\text { Suspended- } \\
\text { sediment } \\
\text { concentration } 1 \\
(\mathrm{mg} / \mathrm{L})\end{array}$ & $\begin{array}{c}\text { Suspended } \\
\text { sediment } \\
\text { discharge } \\
\text { (tons) }\end{array}$ \\
\hline \multicolumn{4}{|l|}{1973} \\
\hline October -- --- & 10 & 193 & 12.2 \\
\hline November ------ & 63 & 810 & 139 \\
\hline December --- & 68 & 691 & 144 \\
\hline \multicolumn{4}{|l|}{1974} \\
\hline January --_-_-- & 137 & 373 & 144 \\
\hline February -- & 70 & 141 & 29.2 \\
\hline March -- & 56 & 42 & 6.7 \\
\hline April $\ldots$ & 73 & 351 & 156 \\
\hline May _-_- & 25 & 467 & 47.1 \\
\hline June --_- & 31 & 551 & 57.5 \\
\hline July -- - & 4.0 & 56 & .60 \\
\hline August ------ & 7.8 & 444 & 9.3 \\
\hline September ------ & 20 & 674 & 37.1 \\
\hline
\end{tabular}

${ }^{1}$ Weighted with water discharge.
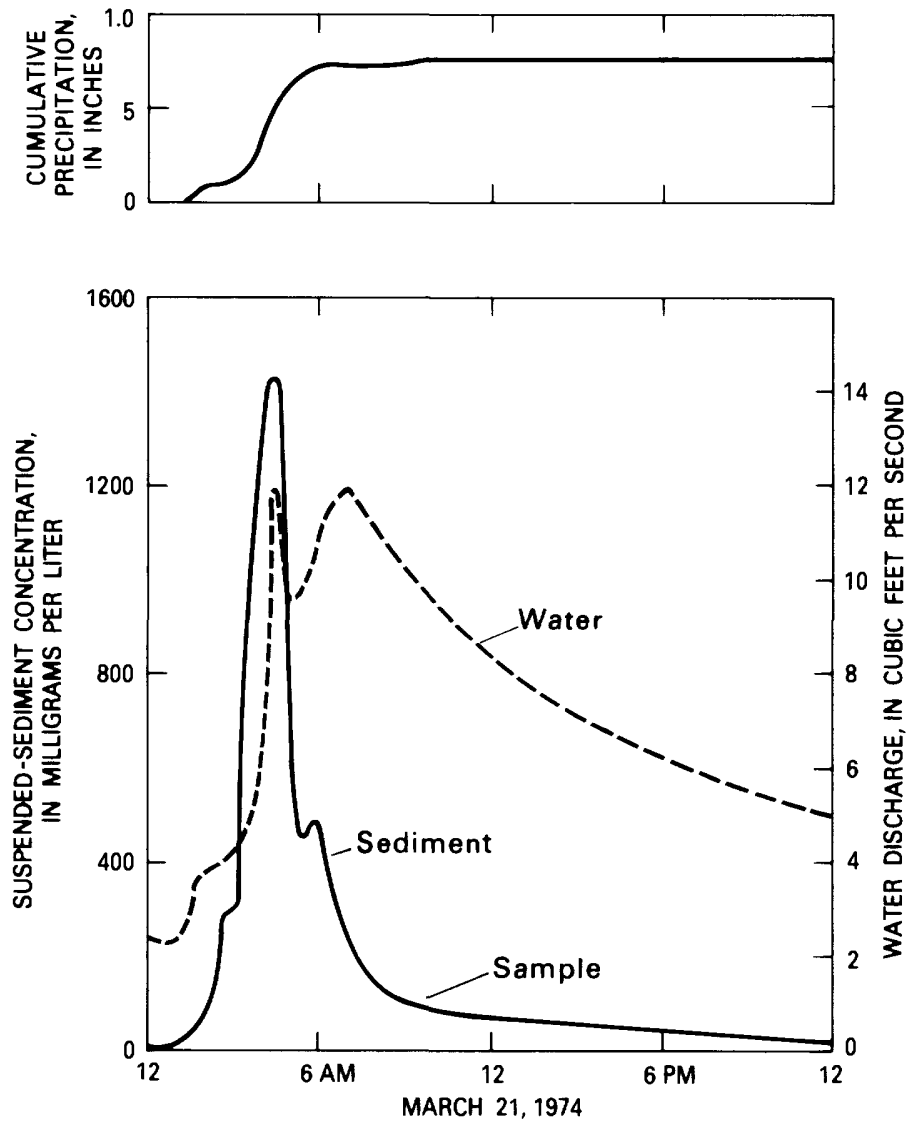

Figure 28.-Relation of suspended-sediment concentration to precipitation and water discharge. Cane Branch near Parkers Lake, March 21, 1974.

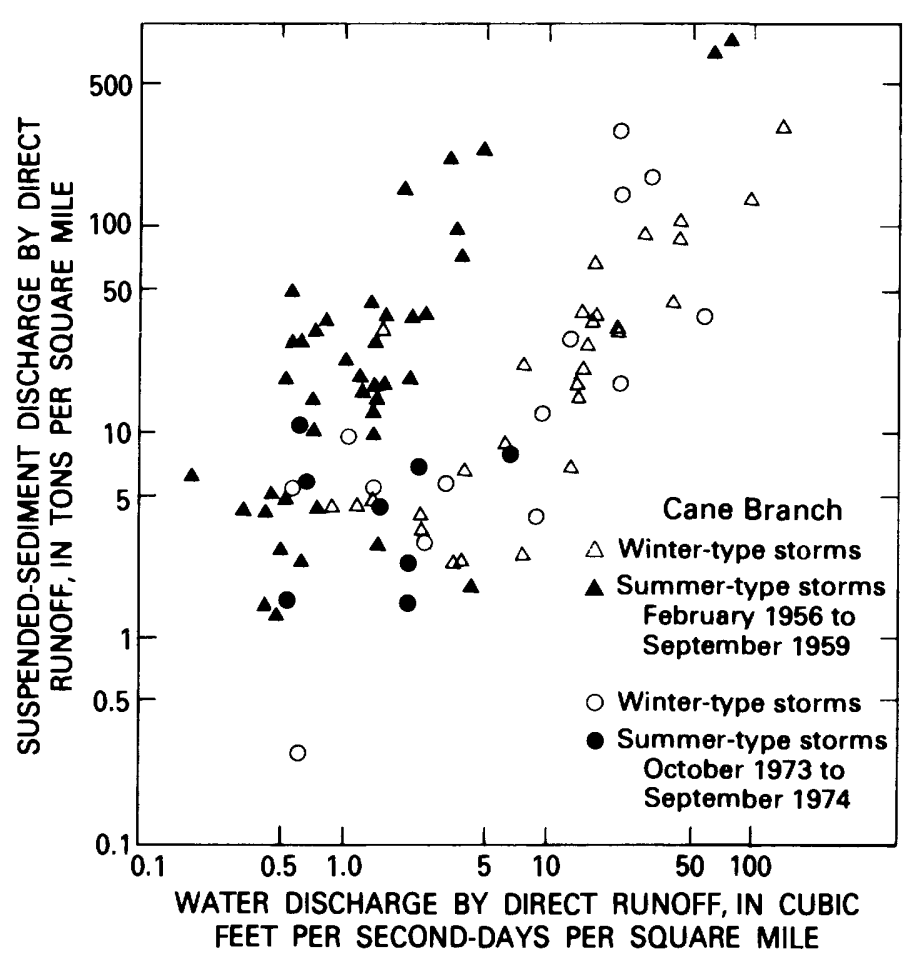

FIGURE 29.-Relation of suspended-sediment discharge to water discharge by storms, Cane Branch near Parkers Lake.

\section{STREAM-BOTTOM FAUNA}

By Albert R. Jones

Kentucky Department of

Fish and Wildlife Resources

The purposes of this study were to describe and evaluate the bottom-fauna composition of streams receiving strip-mine acid effluent, specifically Cane Branch and Hughes Fork, and to relate this information to the bottom-fauna composition of two control streams, Helton Branch and Little Hurricane Fork. The results of bottom-fauna studies in these streams during 1956-58 were reported by Bernard T. Carter (in Collier and others, 1964, p. B80-B83); results of studies during 1959-65 were reported by James P. Henley (Collier and others, 1970 , p. C46-C49). In this report, data on bottom fauna in the sampled streams for 1974 are presented, and relative abundance of key-insect orders in Hughes Fork and Little Hurricane Fork are compared for the entire study period.

\section{METHODS}

Bottom-fauna samples were taken throughout the length of each stream during June 1974; sample sites used by Henley from 1959 through 1965 were duplicated whenever possible. 
All samples were taken from the riffle areas at each station with a Surber square-foot sampler. The macrobenthos was separated from the large bottom materials, and the remaining benthic organisms and detritus were preserved in alcohol for later identification. The data are presented on a square-foot basis.

TABLE 22.-Average number of bottom-fauna organisms per square foot in tributaries to Beaver Creek, June 1974

\begin{tabular}{|c|c|c|c|c|}
\hline \multirow[b]{2}{*}{ Class and order } & \multicolumn{2}{|c|}{ Affected streams } & \multicolumn{2}{|c|}{ Unaffected streams } \\
\hline & $\begin{array}{c}\text { Cane } \\
\text { Branch }\end{array}$ & $\begin{array}{l}\text { Hughes } \\
\text { Fork }\end{array}$ & $\begin{array}{l}\text { Helton } \\
\text { Branch }\end{array}$ & $\begin{array}{c}\text { Little } \\
\text { Hurricane } \\
\text { Fork }\end{array}$ \\
\hline \multicolumn{5}{|l|}{ Crustacea: } \\
\hline Decapoda - - & 0 & 0 & 0.5 & 0.2 \\
\hline \multicolumn{5}{|l|}{ Insecta: } \\
\hline Trichoptera ----- & 0 & 2.5 & 6.5 & 6.8 \\
\hline Plecoptera - & 0 & 2.8 & 5.5 & 4.8 \\
\hline Diptera - - & 0 & .3 & 1.0 & .7 \\
\hline Ephemeroptera --- & 0 & 1.7 & 8.0 & 4.3 \\
\hline Odonata - & .5 & .5 & 1.0 & .5 \\
\hline Megaloptera -.---- & 0 & .2 & 0 & 0 \\
\hline Coleoptera - - - & 0 & .2 & .5 & 1.8 \\
\hline Collembola -- & .5 & 0 & 0 & 0 \\
\hline Neuroptera --_--- & 0 & .3 & 0 & .3 \\
\hline \multicolumn{5}{|l|}{ Amphibia: } \\
\hline Caudata -- & 0 & 0 & .5 & 0 \\
\hline Total - - & 1.0 & 8.5 & $\overline{23.5}$ & $\overline{19.4}$ \\
\hline
\end{tabular}

\section{RESULTS}

The results of bottom-fauna sampling during June 1974 are presented in table 22 by class and order, to permit comparision of bottom-fauna production in streams affected by acid-mine drainage with production in unaffected streams.

There is definite evidence that adverse environmental factors were still present and affecting the production of stream-bottom fauna in Cane Branch when samples were taken in June 1974. In Helton Branch, 23.5 organisms per square foot of stream bottom were present, while in an equal area of stream bottom in Cane Branch only 1 organism was present.

An analysis of data collected from Hughes Fork below the mouth of Cane Branch and Little Hurricane Fork (the stream to which Helton Branch is a tributary) further illustrates the adverse effect of Cane Branch effluent on the bottom fauna in 1974. The samples from these two streams were similar with respect to types of bottom fauna present; however, Hughes Fork supported a mean of 8.5 organisms per square foot, while Little Hurricane Fork supported a mean of 19.4 organisms per square foot.

\section{COMPARISON OF ACCUMULATED BOTTOM-FAUNA DATA}

Mayfly nymphs (Ephemeroptera), caddis fly larvae (Trichoptera), and beetle larvae (Coleoptera) are important aquatic insect groups and are indicative of clean, unpolluted streams in eastern Kentucky. Therefore, the relative abundance of these three orders in Little Hurricane Fork and Hughes Fork was used to test for possible stream-habitat improvement in Hughes Fork (table 23).

This comparison reveals considerable variation in the relative abundance of these orders throughout the study period. However, these data reveal that from 1960 through 1964 , and again in 1974 , the ratio of the combined mean for these organisms at Little Hurricane Fork and Hughes Fork decreased during each sampling period (from 192:trace in 1960 to 13:5 in 1974). It is axiomatic, from these data, that the production of these organisms in these two streams is approaching equality. This is due primarily to an improvement of habitat in Hughes Fork.

\section{CONCLUSIONS}

Bottom-fauna data from the Beaver Creek basin taken during 1956-66 and again in 1974 reveal that the acid and sediment drainage from coal-strip mining has resulted in a loss of invertebrate bottom fauna in Cane Branch and Hughes Fork. Some recovery apparently had occurred by 1974 in Hughes Fork.

\section{FISH POPULATION \\ By John L. Boaze \\ U.S. Fish and Wildlife Service}

The purpose of this phase of the work was to describe the changes that have taken place in the fish populations of the streams of Beaver Creek basin since 1966. Previous fishery studies by Smith (in Collier and others, 1964) during 1956-58 and Sheridan (in Collier and others, 1970) during 1959-66 have documented the effects of acid-mine drainage on the fish populations in the basin.

Cane Branch became devoid of fish life when its water became highly acidic as a result of surface mining of coal during 1955-56 (Smith, in Collier and others, 1964, p. B81). Between 1956 and 1964, the fish population below the confluence of Cane Branch and Hughes Fork, which receives the acidic water, was very limited (Sheridan, in Collier and others, 1970, p. C53).

Fish-population sampling was not conducted on any of the streams within the study area prior to surface mining in the Beaver Creek basin. However, it is 
TABLE 23.-Average number per square foot of Ephemeroptera, below the mouth of Cane Branch in [LHF $=$ Little Hurricane Fork;

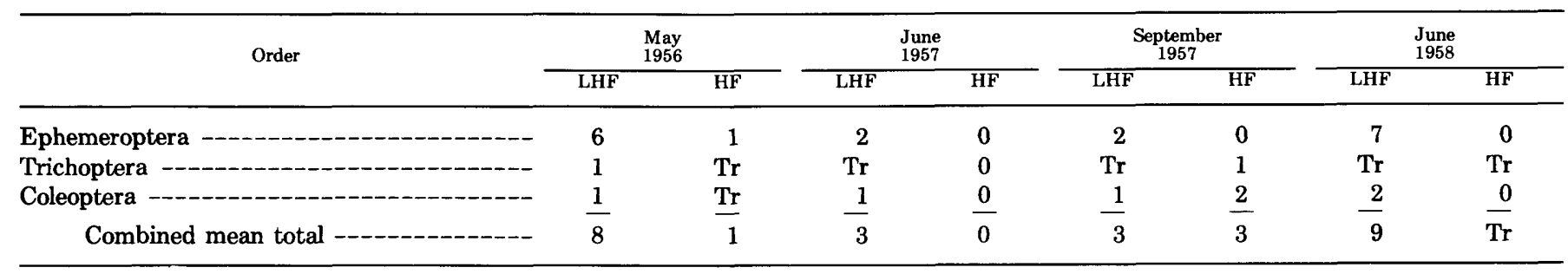

reasonable to assume that the affected streams supported fish populations similar to the reference streams. Smith (in Collier and others, 1964) reported a reduced fish population in Cane Branch until June 1956, after which time all fish life disappeared.

\section{METHODS OF CONDUCTING FISH-POPULATION STUDIES}

Fish-population sampling was conducted in conjunction with bottom-fauna sampling during the early summer of 1973 and 1974, but only the fish population was sampled during the fall of 1973.

In both previous studies and in this study, Helton Branch, Little Hurricane Fork, and Hughes Fork above the confluence with Cane Branch were used as unaffected reference streams. Cane Branch and Hughes Fork below the confluence with Cane Branch were sampled to determine the continuing influence of the acidmine drainage (fig. 30).

All samples were collected by the use of cresol, which was applied by the Kentucky Fish and Wildlife Resources biologist. Streamflows were estimated but surface areas and $\mathrm{pH}$ of the water were measured prior to the cresol application. Each sampling section consisted of approximately equal areas of riffles and pools.

Virtually all fish were captured with dip nets for identification and measurement and released back into the streams.

\section{RESULTS OF SAMPLING FISH POPULATIONS}

The results of the 1973-74 fish-population sampling in the Beaver Creek basin are presented in table 24. As in previous studies, Cane Branch was devoid of fish life during the sampling periods of this study. Hughes Fork supported only a limited fish population below the confluence of Cane Branch in contrast to the reference streams.

\begin{tabular}{|c|c|c|c|c|}
\hline Date & $\underset{\left(\mathrm{ft}^{2}\right)}{\text { Sample area }}$ & $\begin{array}{c}\text { Fish per } \\
\text { acre } \\
\text { (numbers) }\end{array}$ & $\begin{array}{l}\text { Fish per } \\
\text { acre } \\
\text { (pounds) }\end{array}$ & $\underset{\text { (units) }}{\mathrm{pH}}$ \\
\hline \multicolumn{5}{|c|}{ Affected streams } \\
\hline \multicolumn{5}{|c|}{ Cane Branch at gaging station } \\
\hline $7-12-73$ & 670 & 0 & 0 & 4.2 \\
\hline $10-29-73$ & 670 & $\mathbf{0}$ & 0 & 3.4 \\
\hline $6-26-74$ & 670 & 0 & 0 & 3.7 \\
\hline Mean & & 0.0 & 0.0 & \\
\hline \multicolumn{5}{|c|}{ Hughes Fork (station 2) } \\
\hline $6-26-73$ & 3,960 & 11 & 0.4 & 6.9 \\
\hline $10-30-73$ & 3,960 & 66 & 3.5 & 6.0 \\
\hline $6-25-74$ & 3,960 & 66 & 2.2 & 8.0 \\
\hline Mean & & 47.7 & 2.0 & \\
\hline \multicolumn{5}{|c|}{ Hughes Fork (station 1) } \\
\hline $6-26-73$ & 3,000 & 494 & 6.4 & 6.8 \\
\hline $10-30-73$ & 3,000 & 0 & 0 & 6.5 \\
\hline $6-25-74$ & 3,000 & 160 & 3.4 & 6.8 \\
\hline Mean & & 218.0 & 3.3 & \\
\hline \multicolumn{5}{|c|}{ Reference streams } \\
\hline \multicolumn{5}{|c|}{ Helton Branch at gaging station } \\
\hline $6-27-73$ & 2,160 & 102 & 3.0 & 6.8 \\
\hline $10-29-73$ & 2,160 & 101 & 2.4 & 6.6 \\
\hline $6-26-74$ & 2,160 & 202 & 1.3 & 7.9 \\
\hline Mean & & 135.0 & 2.2 & \\
\hline \multicolumn{5}{|c|}{ Hughes Fork above Cane Branch (station 3) } \\
\hline $6-26-73$ & 2,320 & 583 & 8.8 & 6.7 \\
\hline $10-30-73$ & 2,320 & 132 & 3.5 & 7.0 \\
\hline $6-25-74$ & 2,320 & 864 & 15.9 & 8.0 \\
\hline Mean & & 526.3 & 9.4 & \\
\hline \multicolumn{5}{|c|}{ Little Hurricane Fork (station 1) } \\
\hline $7-13-73$ & 1,165 & 373 & 6.6 & 7.3 \\
\hline $10-30-73$ & 1,165 & 299 & 3.4 & 6.3 \\
\hline $6-24-74$ & 1,165 & 187 & 2.4 & 7.4 \\
\hline Mean & & 286.3 & 4.1 & \\
\hline \multicolumn{5}{|c|}{ Little Hurricane Fork (station 2) } \\
\hline $6-27-73$ & 1,600 & 182 & 1.6 & 7.1 \\
\hline $10-29-73$ & 1,600 & 681 & 3.4 & 6.4 \\
\hline $6-24-74$ & 1,600 & 218 & 2.1 & 7.7 \\
\hline Mean & & 360.3 & 2.4 & \\
\hline
\end{tabular}


Trichoptera, and Coleoptera in Little Hurricane Fork and Hughes Fork selected months, 1956-62, 1964, and 1974

$\mathrm{HF}=$ Hughes Fork; $\mathrm{Tr}=$ trace]

\begin{tabular}{|c|c|c|c|c|c|c|c|c|c|c|c|}
\hline \multicolumn{2}{|c|}{$\begin{array}{l}\text { June } \\
1959\end{array}$} & \multicolumn{2}{|c|}{$\begin{array}{l}\text { June } \\
1960\end{array}$} & \multicolumn{2}{|c|}{$\begin{array}{l}\text { June } \\
1961\end{array}$} & \multicolumn{2}{|c|}{$\begin{array}{l}\text { June } \\
1962\end{array}$} & \multicolumn{2}{|c|}{$\begin{array}{c}\text { August } \\
1964\end{array}$} & \multicolumn{2}{|c|}{$\begin{array}{l}\text { June } \\
1974\end{array}$} \\
\hline LHF & HF & LHF & $\mathrm{HF}$ & LHF & $\mathrm{HF}$ & $\overline{\text { LHF }}$ & $\overline{\mathrm{HF}}$ & LHF & $\mathrm{HF}$ & LHF & $\overline{\mathrm{HF}}$ \\
\hline 44 & $\operatorname{Tr}$ & 102 & $\operatorname{Tr}$ & 117 & $\mathrm{Tr}$ & 21 & $\mathrm{Tr}$ & 20 & 1 & 4 & 2 \\
\hline 10 & $\operatorname{Tr}$ & 42 & $\operatorname{Tr}$ & 53 & 6 & 16 & 2 & 15 & 4 & 7 & 3 \\
\hline 6 & $\operatorname{Tr}$ & 48 & $\mathrm{Tr}$ & 55 & 1 & 12 & $\operatorname{Tr}$ & 8 & 1 & 2 & $\operatorname{Tr}$ \\
\hline 60 & $\operatorname{Tr}$ & 192 & $\operatorname{Tr}$ & 225 & 7 & 49 & 2 & 43 & 6 & 13 & 5 \\
\hline
\end{tabular}

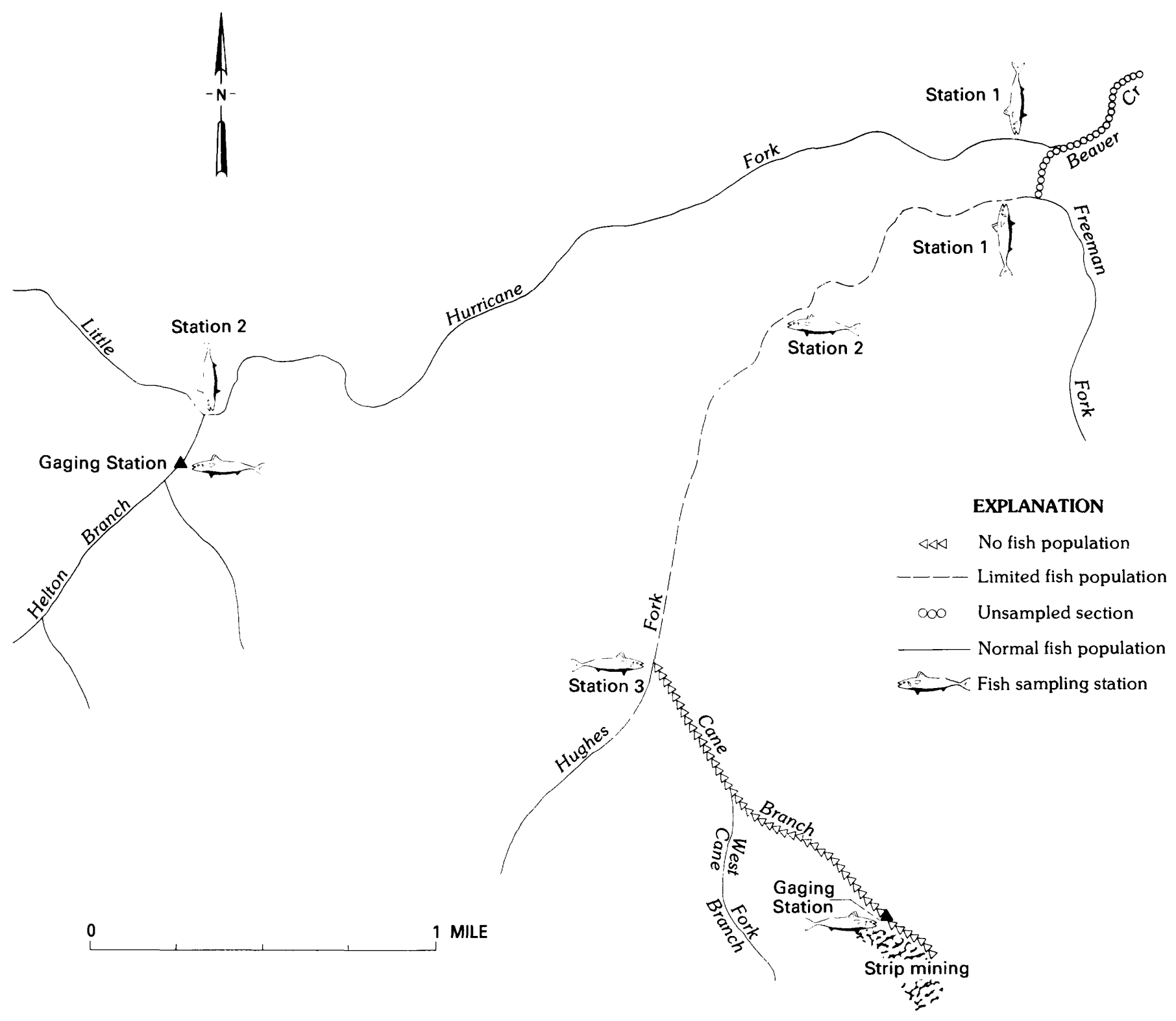

FIGURE 30.-Location of fish-sampling stations and distribution of fish within the Beaver Creek basin, 1973-74. 
Above the confluence with Cane Branch, Hughes Fork was supporting an average of 526.3 fish, or 9.4 pounds of fish per acre. At station 2, located below the confluence with Cane Branch, the fish population of Hughes Fork averaged 47.7 fish, or 2.0 pounds per acre; at station 1, in the lower section of Hughes Fork, the fish population increased to an average of 218.0 fish, or 3.3 pounds per acre. Thus, the relative population abundance at these stations $(1,2$, and 3$)$ probably indicates that the fish fauna in Hughes Fork was most severely degraded just below the confluence with Cane Branch and that population recovery had started farther downstream. During his investigation in 1964, Sheridan (in Collier and others, 1970) reported the presence of fish at stations 1 and 3 but not at station 2 .

Lower $\mathrm{pH}$ values were recorded for Cane Branch than for the reference streams (table 24). The acidity (pH 3.4-4.2 units) of Cane Branch is in the range known to be lethal to fish (Ellis, 1937), although the $\mathrm{pH}$ levels reported for the affected section of Hughes Fork were probably not critical for all species during the 1973-74 sampling period. Prior lower levels may have accounted for their population reduction.

Comparison of the standing stock of the reference of the reference streams with the stock of Cane Branch and Lower Hughes Fork seems to indicate that the effect of surface mining is responsible for depressing or eliminating the fish population in the streams receiving the acid runoff (table 25). The reference streams were supporting 3.7 times as many fish by number and 2.5 times as many fish by weight as the affected streams.

In addition to the quantitative differences in the affected and reference streams, there is indication that surface mining caused qualitative changes in the fish populations of the affected streams. Major differences are seen in the number of species collected in the comparable streams (table 26). The affected streams were supporting no more than two species of fish, while the reference streams supported six or more species of fish. In both the reference and affected streams, the creek chub was the dominant species. The creek chub has been the dominant species of fish in Hughes Fork since 1956 and was the last known species to be present in Cane Branch (Smith, in Collier and others, 1964). This indicates that it is more acid tolerant than other species.

The presence of trout in the streams of the Beaver Creek basin was a result of the National Forest Service's stocking program. Each fall, 600 subadult rainbow trout are planted in Little Hurricane Fork. This small number of fish probably exerts little or no influence on the native fish population within the study area.
TABLE 25.-Comparison of the standing stocks of the affected and reference streams within the Beaver Creek basin, 1973-74

\begin{tabular}{ccc}
\hline Station & $\begin{array}{c}\text { Number of fish collected } \\
\text { per acre per station }\end{array}$ & $\begin{array}{c}\text { Number of pounds of fish collected } \\
\text { per acre per station }\end{array}$ \\
\hline \multicolumn{4}{c}{$327.0^{\text {Reference streams }}$} \\
9 & \multicolumn{2}{c}{4.5} \\
9 & $88.5{ }^{\text {Affected streams }}$ & 1.8 \\
\hline
\end{tabular}

\section{CONCLUSIONS}

Results of fish-population sampling in the Beaver Creek basin indicate that Cane Branch is still devoid of fish due to the low $\mathrm{pH}$ of the water draining from the strip-mined area. The fish population in Hughes Fork below the confluence with Cane Branch was severely restricted in both numbers and species. However, natural stream recovery appears to be taking place, as indicated by the increase in fish population in the lower section of Hughes Fork of Beaver Creek.

\section{TREE GROWTH ON SPOILS}

$$
\begin{aligned}
& \text { By Thomas M. Yanosky } \\
& \text { and Robert S. Sigafoos } \\
& \text { U.S. Geological Survey }
\end{aligned}
$$

Natural reforestation of the mine spoils of 1956 has created a stand of pine trees that by 1974 covered slightly more than one-half of the spoils area. Other species are present, but their basal area is less than 2 percent of that of the pines. This study examined the degree of reforestation and growth rates of trees on the

TABLE 26.-Relative abundance of various species of fish collected

\begin{tabular}{|c|c|c|}
\hline Species & $\begin{array}{l}\text { Number of } \\
\text { fish per } \\
\text { acre }\end{array}$ & Percentage \\
\hline \multicolumn{3}{|l|}{ Affected streams } \\
\hline Creek chub (Semotilus atromaculatus) ---- & 716 & 89.8 \\
\hline Striped darter (Etheostoma virgatum) ---- & 81 & 10.2 \\
\hline Total -- & 797 & 100.0 \\
\hline \multicolumn{3}{|l|}{ Reference streams } \\
\hline Creek chub (Semotilus atromaculatus) ---- & 3,620 & 92.2 \\
\hline Striped darter (Etheostoma virgatum) ---- & 226 & 5.8 \\
\hline Northern hogsucker (Hypentelium nigri- & & \\
\hline cans) - & 19 & .5 \\
\hline Spotted bas (Micropterus punctulatus) --- & 19 & .5 \\
\hline Arrow darter (Etheostoma sagitta) - & 19 & .5 \\
\hline Rainbow trout (Salmo gairdneri) - & 21 & .5 \\
\hline Total -- & 3,924 & 100.0 \\
\hline
\end{tabular}
from the affected and reference stations within the Beaver Creek study area, 1973-74 
mine spoils compared with those of the forest that has grown on an abandoned farm in the same valley and concluded that significantly less vegetation grows on the young (1956) mine spoils than on older mine spoils and on the abandoned farmland. Previous botanical studies were concerned with the effects of acid-mine drainage on trees growing below the mine (see Sigafoos in Collier and others, 1964, p. B66-B76 and in Collier and others, 1970, p. C57-C60) and with the natural establishment of trees on the spoils (Sigafoos in Collier and others, 1964, p. B75-B76). This earlier phase showed that, 10 years after mining, tree seedlings grew on spoils in numbers insufficient to ensure full reforestation and stands of Virginia and shortleaf pine on the spoils exhibited poorer form and fewer numbers of trees than on abandoned farmlands of comparable age.

\section{METHODS}

Fourteen plots were arbitrarily established to sample the trees growing on the spoils of two mines (Musser, 1963, p. A22), on abandoned farmland, and on the upland above the younger mine (fig. 31). The plots, each measuring 0.1 acre, were distributed among four general areas as follows: seven on spoils (plots 7-13, fig. 31) and one above the highwall (plot 6) of the mine abandoned in 1956; two on the mine abandoned in 1947 (plots 1 and 2); three on abandoned farmland southeast of the younger mine (plots 3-5); and one in nearby upland forest above the younger mine (plot 14).

In each plot, trees having trunks 1 inch or more in diameter were identified and measured, and the basal area (the total cross-sectional area of stems at the points of measurement) was calculated. Representative cores were taken to determine ages and radial growth rates of stems on the younger mine spoils, above the high wall, and on the abandoned farmland.

\section{COMPOSITION AND DISTRIBUTION OF VEGETATION IN SAMPLED AREAS}

The forests of Cane Branch basin consist of secondgrowth hardwoods with admixtures of pine and hemlock locally on cut-over land and nearly pure stands of pine species on abandoned farmland. On the uplands above the strip mine are oak-pine and oakhickory forests (Musser, 1963, p. A21). Virginia pine and shortleaf pine account for the largest number (51 percent) of trees tallied on spoils plots. Blackgum, sweetgum, red maple, serviceberry, persimmon, and princess tree are less common. Woody shrubs (blackberry, gooseberry, and sumac) and greenbrier and poison-ivy vines are sporadically present, as is a variety of herbaceous forms not considered in this report. Lichens are common on rocks and tree trunks throughout the mine area.
More species are present and growth is more dense on the spoils of the mine abandoned in 1947 than on the younger mine. Vegetation has had nearly 10 more years to grow on the older spoils, and the site is a moist valley bottom near the head of Cane Branch. Additional time and water and possible differences in soil characteristics may account for the denser and more diverse vegetation. The uncommon climbing fern (Lygodium palmatum (Bernh.)) is abundant on the older mine spoils.

According to J. E. Patrick, Honeybee, Ky., at least part of the bottom and gentle slopes on the southeastern side of the valley enclosing plots 3,4 , and 5 were once farmed (personal commun., January 10, 1974). Ages of trees on the site suggest that part of the farm was not cultivated after 1938 . Patrick moved onto the land in 1941, but he did not farm the area and all cultivation ceased. Natural reforestation that followed has resulted in the growth of dense pine woods on the slopes. The bottom is covered with dense growths of grass and blackberries along with scattered deciduous trees.

The upland area (plot 14) is near the northwestern end of the younger mine, and the forest is composed primarily of oak species, pignut hickory, and sourgum. Sourwood, red maple, and Virginia and shortleaf pines are also present. Dogwood, shagbark hickory, silverbell, and staghorn sumac account for the remaining woody plants in the basal area plot. The forest was poorly stocked when first surveyed (Musser, 1963, p. A21); that is, it contained fewer trees than needed for maximum forest growth, and probably remains so, partly because it was lumbered prior to the start of the study in 1958.

\section{QUANTITY OF VEGETATION}

The distribution and density of vegetation on mine spoils reflects the great variability of site factors in the mined areas. Many sites, particularly on the highwall or on the steep outer slopes of spoils, or those with internal drainage, support little or no woody vegetation. The trees on these sites exhibit poorer form and size than those growing in denser stands on the spoils.

The number of woody stems, basal area, and the crown density of the trees are variable in the four general areas. Table 27 summarizes the number and basal area for all species measured in one-tenth acre plots. Basal area for trees on each plot is shown in figure 32 . Crown density of pine trees on the younger mine spoils and the abandoned farmland was estimated from 1:10,000 scale aerial photographs using a dot grid. The pine trees on the mine spoils are not discernible on the 1959 photographs, whereas they have a density of 55 


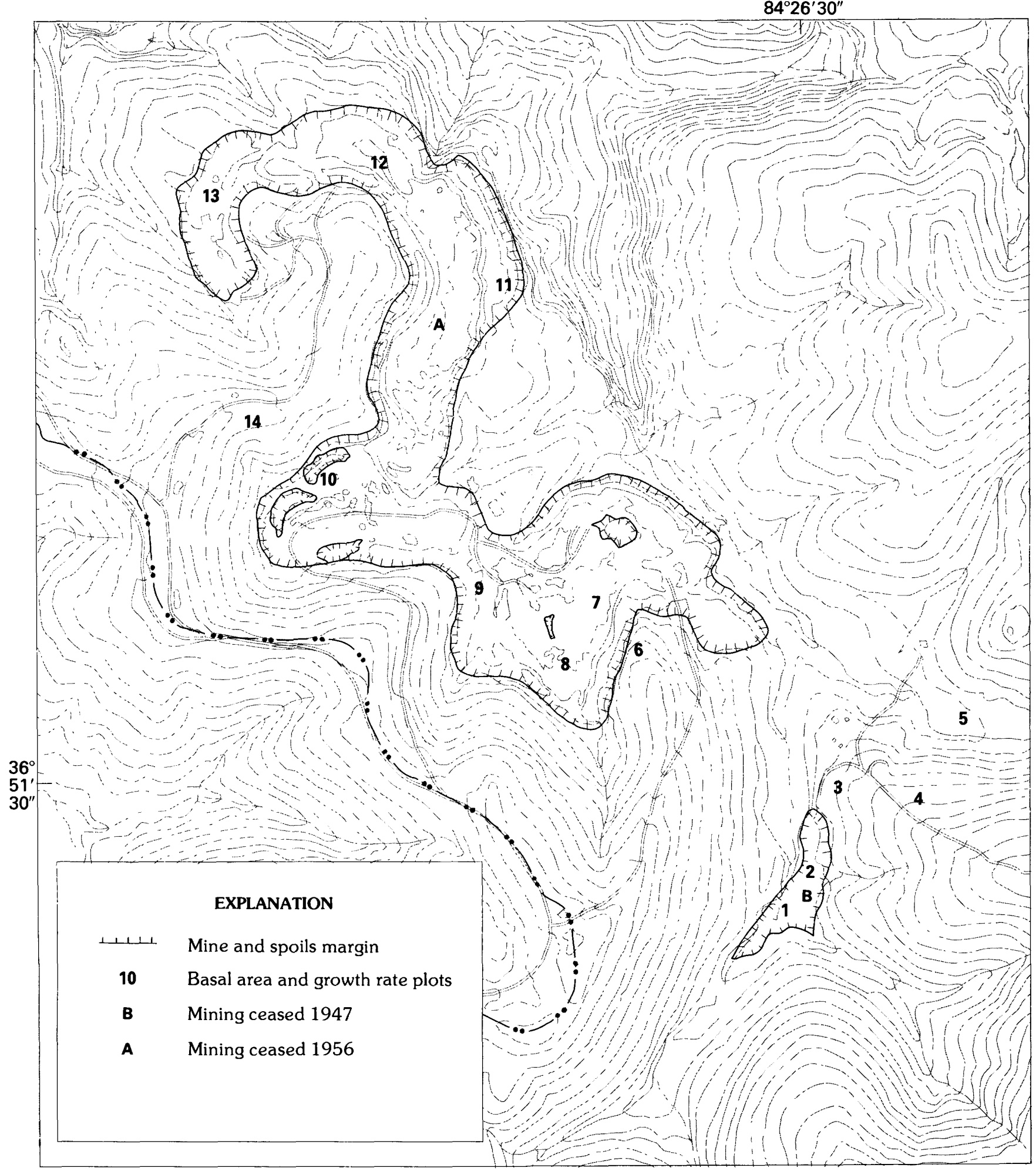

Figure 31.-Cane Branch basin and location of forest plots. 
TABLE 27.-Mean number and mean basal area of species ${ }^{1}$ in four areas in Cane Branch basin [Basal area, BA, in square feet per acre]

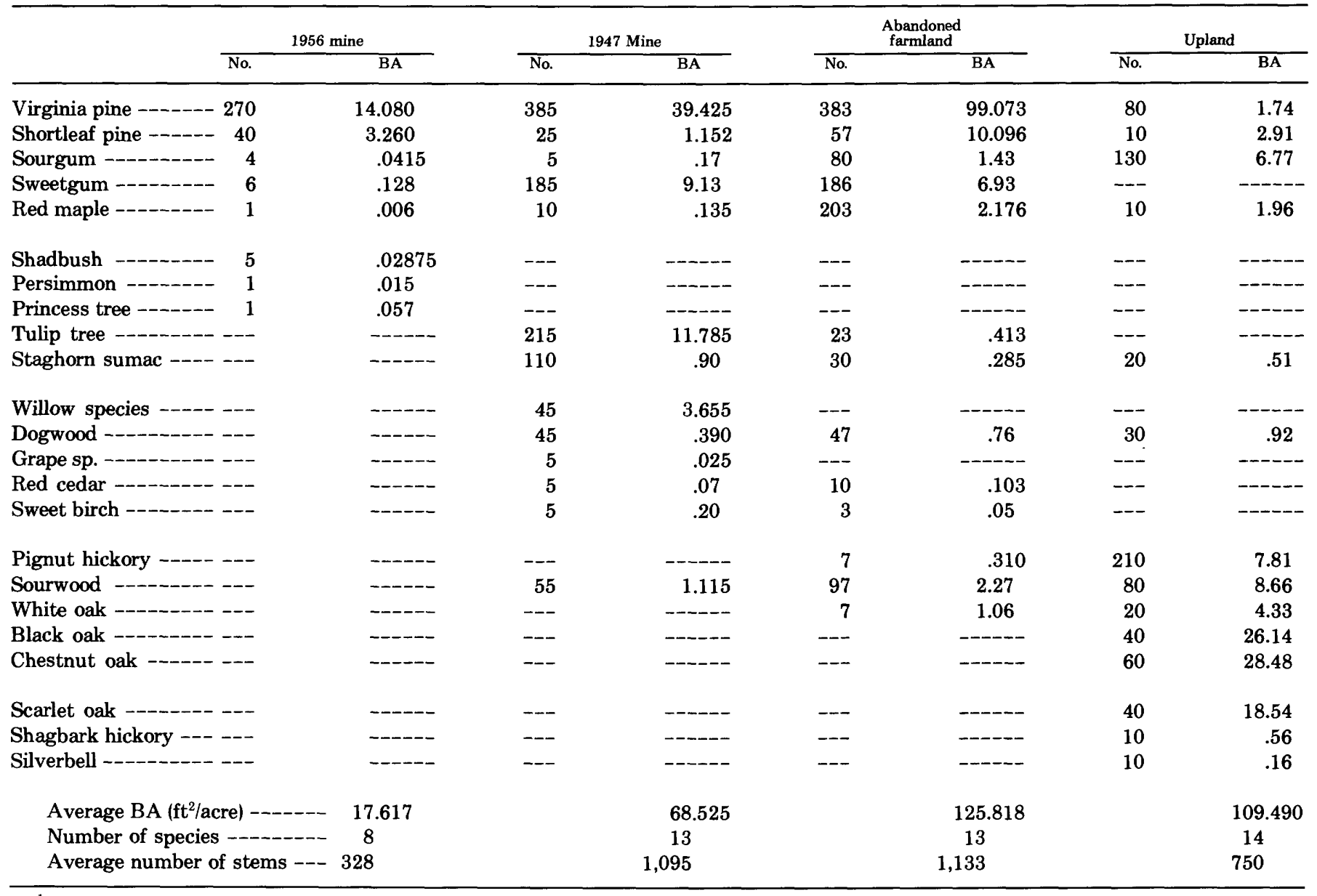

${ }^{1}$ See table 29 for scientific names of tree species.

percent in the January 1974 photographs. Crown density of pines on the abandoned farmland was 92 percent in 1959 and 93 percent in 1974. The density of pines on the abandoned farmland is essentially the same for these two years, but the area covered by pines was slightly larger in 1974 .

The number of species, number of stems, and basal area of trees are markedly different on the young spoils compared with the other three areas. Crown densities are also different between trees on the young spoils and abandoned farmland. The lower basal-area values for trees on the young spoils can be due to lower number of stems per unit area or to slower growth rates on the spoils.

\section{GROWTH RATE OF TREES ON SPOILS AND ON AN ABANDONED FARM}

To determine rate of radial tree growth, 66 cores were collected from trees on the young mine spoils and
14 from trees on the abandoned farmland. Trees on the spoils ranged in age from 12 to 17 years and in diameter from 1.0 inch to 11.4 inches, whereas on the abandoned farmland they ranged in age from 31 to 35 years and in diameter from 7.5 inches to 12.4 inches.

The majority of cores (53) from trees on the spoils were Virginia or shortleaf pine. These species are presently most abundant and are the original woody vegetation that invades bare spoils areas (Sigafoos in Collier and others, 1964, p. B75). Owing to dissimilar patterns of development, comparisons of growth data for different genera must be made with caution. In the present study, deciduous genera are insufficient in both age and sample numbers, and thus those data are not included in the calculations. Virginia and shortleaf pine, however, show no discernible growth differential; the larger proportion of Virginia pine is probably due to this species' greater ability to become established in open environments (U.S. Department of Agriculture, 1965a, p. 474). 


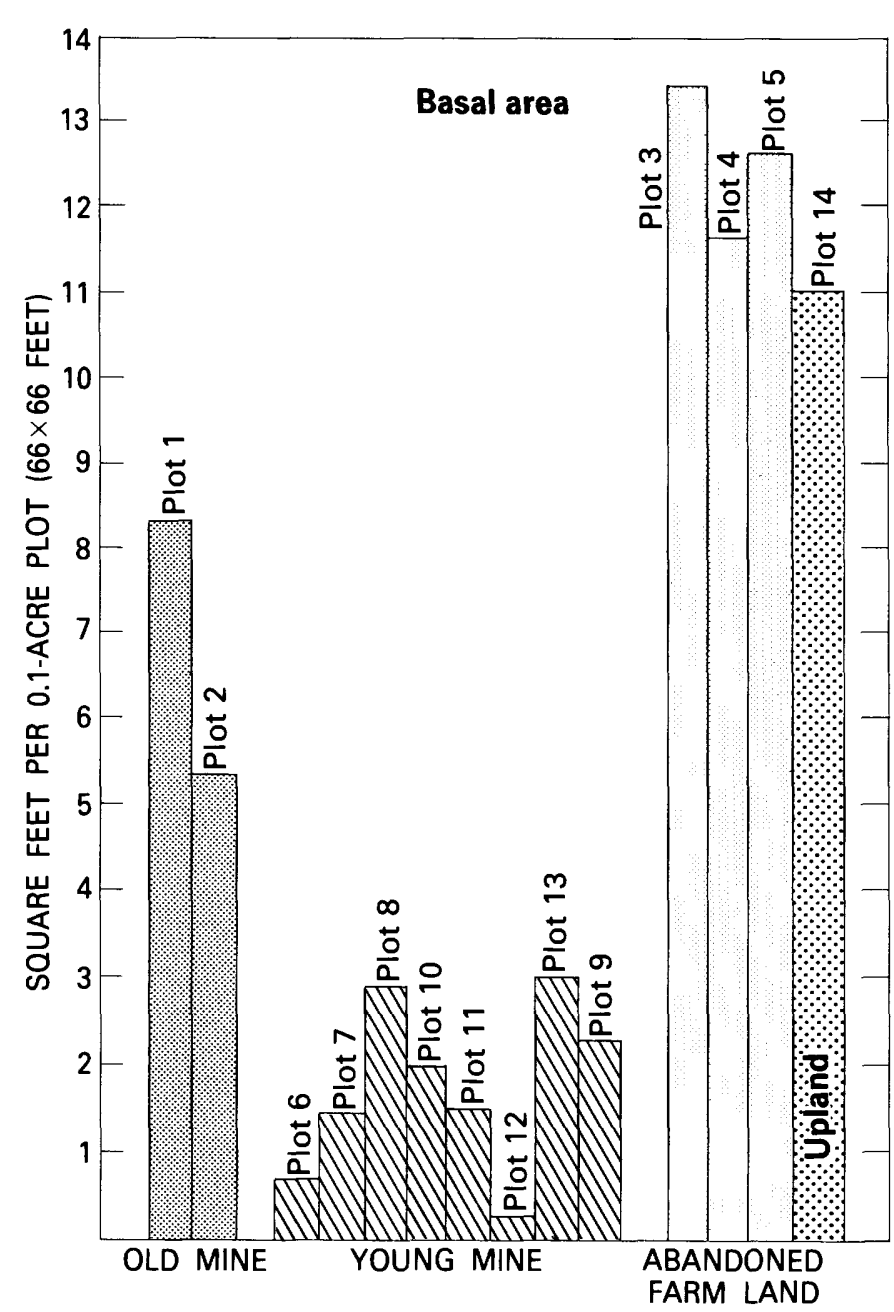

FIGURE 32.-Basal area of all woody stems 1 inch or larger in diameter for all plots.

Mining activities ceased in June 1956, and natural reforestation of bare spoils probably began the following spring, resulting in a maximum possible age of 17 years for the present trees. Only two sampled trees were of maximum age, a result consistent with the previous observation that initial seedling numbers were insufficient for adequate reforestation (Collier and others, 1964, p. B76). As a result, the growth rate of woody vegetation invading bare spoils soon after mining ceased was calculated from 37 individuals germinating within 5 years following abandonment. Only the older trees were studied to compare growth rates of trees in similar climates on sites that probably had a similar degree of weathering. Growth rates of younger trees might well be different from older trees because the younger trees may have started to grow in the shade of older trees, and because younger trees started to grow on sites where weathering of minerals had progressed beyond that characteristic of the initial seed bed in 1956.
TABLE 28.-Growth rates of pine trees on the young mine spoils and on abandoned farmland

\begin{tabular}{lccc}
\hline & $\begin{array}{c}\text { First 25-mm } \\
\text { increment }\end{array}$ & $\begin{array}{c}\text { Second 25-mm } \\
\text { increment }\end{array}$ & $\begin{array}{c}\text { Range in age } \\
\text { of sampled } \\
\text { trees } \\
\text { (years) }\end{array}$ \\
\hline High wall ------------- & 11.93 & --- & $12-15$ \\
Young mine spoils ------- & 5.49 & 5.34 & $12-17$ \\
Abandoned farmland ------ & 5.34 & 4.30 & $31-35$ \\
\hline
\end{tabular}

${ }^{1}$ Average of total radial growth (radii of five out of six trees are less than $35 \mathrm{~mm}$ ).

Rings were counted in two successive 25-millimeter increments from the pith to the cambium. Fractions were adjusted to the nearest half-ring. From these data the average width of rings in each 25 -millimeter increment was calculated. Ring widths of cores from trees on the young spoils (plots $7-13$ ) averaged $5.49 \mathrm{~mm}$ in the first 25-millimeter increment and $5.34 \mathrm{~mm}$ in the second increment (table 28).

Trees were also sampled in the plot above the highwall to evaluate the growth rate on the site disturbed but not as drastically altered as the spoils. The trees (plot 6) showed significantly poorer growth, as the radii of five out of six individuals were less than $35 \mathrm{~mm}$. Total ring width of high wall trees averaged $1.93 \mathrm{~mm}$ (table 28). The slower growth rate is probably due to dry soils in summer, as the site and forested slope above it is a gently rounded slope.

Growth data based on core samples of trees growing on young spoils were compared to trees on the abandoned farmland. Table 28 summarizes these growth rates. No significant difference exists in the first $25 \mathrm{~mm}$ of radial growth between trees on young mine spoils and those on the abandoned farmland. In the second $25 \mathrm{~mm}$ increment, however, tree growth on young spoils was greater than tree growth on the abandoned farmland, suggesting either accelerated stimulation of growth on spoils or slowing of growth on the farmland because of closing of the canopy. Due to scattered distributional patterns on the mine spoils, the effects of crowding were minimized. On the other hand, the greater number of stems supported on variable tracts of abandoned farmland is well documented, with as many as 1,600 pines per acre tallied on a 20-year-old plantation (McIntire, 1933). Crowded stems generally show less growth than comparable individuals growing in open conditions.

\section{CONCLUSIONS}

The significantly smaller amount of vegetation on the younger mine spoils than on the older mine spoils, 
abandoned farmland, and upland probably is related to poorer site conditions on the younger spoils. Basal area of pines on the spoils is less than on the abandoned farmland because fewer trees per unit area grow on the spoils, as reflected in density values. Although trees on the young spoils are younger than those on the abandoned farmland, time alone cannot account for the differences in quantity of vegetation. Comparable growth rates of trees on the two sites indicate that, in places on the spoils, trees grow as well as on unmined areas. The number, form, and density indicate the overall negative influence of strip mining on woody vegetation. Reforestation of those parts of the mined areas now inadequately forested will undoubtedly continue, and future studies are needed to document their rate of recovery.

\section{SELECTED REFERENCES}

Collier, C. R., and others, 1964, Influences of strip mining on the hydrologic environment of parts of Beaver Creek basin, Kentucky, 1955-59: U.S. Geological Survey Professional Paper $427-\mathrm{B}, 85 \mathrm{p}$.

Collier, C. R., Pickering, R. J., and Musser, J. J., 1970, Influences of strip mining on the hydrologic environment of parts of
Beaver Creek basin, Kentucky, 1955-66: U.S. Geological Survey Professional Paper 427-C, 80 p.

Ellis, M. M., 1937, Detection and measurement of stream pollution: U.S. Bureau of Fish and Wildlife Bulletin 22, v. 48, p. 365-437.

Gleason, H. A., and Cronquist, Arthur, 1963, Manual of vascular plants of northeastern United States and adjacent Canada: New York, van Nostrand, $810 \mathrm{p}$.

Little, E. L., 1953, Check list of native and naturalized trees of the United States: U.S. Forest Service Agricultural Handbook 41, $472 \mathrm{p}$.

McIntyre, A. C., 1933, Virginia pine in Pennsylvania: Pennsylvania Agricultural Experiment Station Bulletin 300, 31 p.

Musser, J. J., 1963, Description of physical environment and of strip-mining operations in parts of Beaver Creek basin, Kentucky: U.S. Geological Survey Professional Paper 427-A, 25 p.

U.S. Department of Agriculture, 1965a, Sylvics of forest trees of the United States: U.S. Forest Service Agriculture Handbook 271, 762 p.

1965b, Predicting rainfall-erosion losses from cropland east of the Rocky Mountains: U.S. Department of Agriculture Handbook 282 .

1972, Procedure for computing sheet and rill erosion on project areas: U.S. Department of Agriculture, Soil Conservation Service, Engineering Technical Release 51.

Wilkins, L. P., 1955, Observations on the field use of cresol as a stream-survey method: Progressive Fish Culturist, v. 17, April, p. $85-86$. 

TABLES 29-36 
TABLE 29.-List of common and scientific names of woody species

Common name

Scientific name

Birch, sweet --_-_-- Betula Lenta L.

Blackberry -------- Rubus L.

Blackgum -..---- Nyssa sylvatica Marsh.

Dogwood -..-_-_- Cornus florida L.

Gooseberry --.---- Ribes L.

Grape -.-_-_-_-- Vitis L.

Greenbrier --..-...- Smilax rotundifolia L.

Hickory, pignut ----- Carya glabra (Mill.) Sweet

Hickory, shagbark --- Carya ovata (Mill.) K. Koch

Maple, red --.--.--- Acer rubrum L.

Oak, black --_-_--- Quercus velutina Lam.

Oak, chestnut -.---- Quercus prinus L.

Oak, scarlet -...--- Quercus coccinea Muenchh.

Oak, white --_-_-_ Quercus alba $\mathrm{L}$.

Persimmon -...--- Diospyros virginiana $\mathrm{L}$.

Pine, shortleaf --.---- Pinus echinata Mill.

Pine, Virginia -_-_--- Pinus virginiana Mill.

Poison ivy - -..-- Rhus radicans $\mathrm{L}$.

Princess tree --.--- Paulownia tomentosa (Thumb.) Sieb. \& Zucc

Redcedar, eastern --- Juniperus virginiana L.

Serviceberry -..----- Amelanchier Med.

Silverbell ---------- Halesia carolina $\mathrm{L}$.

Sourwood --_-_-- Oxydendrum arboreum (L.) D.C.

Sumac, staghorn ---- Rhus typhina L.

Sweetgum -------- Liquidambar styraciflua $\mathrm{L}$.

Yellow-poplar -------- Liriodendron tulipifera L.

Willow --_-.--- Salix L.

Note: Nomenclature of trees follows that of Little (1953), and vines that of Gleason and Cronquist (1963).
TABLE 30.-Discharge and runoff at the Cane Branch near Parkers Lake stream-gaging station

Location-Lat. $36^{\circ} 52^{\prime} 05^{\prime \prime}$, long. $84^{\circ} 26^{\prime} 57^{\prime \prime}$, McCreary County, on left bank $2,100 \mathrm{ft}$ up stream from West Fork 2.5 mi northeast of Parkers Lake and 2.6 mi east of Greenwood. Drainage area- $0.67 \mathrm{mi}^{2}$.

Period of record-February 1956 to September 1966 (continuous record station); October 1966 to April 1973 (annual maximums and occasional low-flow measurements); May 1973 to September 1974 (continuous-record station).

Gage-Water-stage recorder and concrete control. Datum of gage is $979.4 \mathrm{ft}$ above sea level (levels by U.S. Forest Service).

Average discharge-11 years $(1956-66,1974), 0.914 \mathrm{ft}^{3} / \mathrm{s}, 18.53 \mathrm{in} . / \mathrm{yr}$.

Extremes-Period of record: Maximum discharge, $236 \mathrm{ft}^{3} / \mathrm{s}$, August 9, 1970 (gage height, $2.00 \mathrm{ft}$ ); maximum gage height, $2.43 \mathrm{ft}$, January 29, 1957 (backwater from ice); minimum discharge, $0.005 \mathrm{ft}^{3} / \mathrm{s}$, September $7,8,1957$.

\begin{tabular}{|c|c|c|}
\hline & & Runoff \\
\hline Month & $\begin{array}{c}\text { discharge } \\
\left(\mathrm{ft}^{3} / \mathrm{s}\right)\end{array}$ & $\left(\mathrm{ft}^{3} / \mathrm{s}\right) / \mathrm{mi}^{2} \quad$ inches \\
\hline
\end{tabular}

Water year ending September 30, 1973

\begin{tabular}{|c|c|c|c|}
\hline May - & 1.89 & 2.82 & 3.25 \\
\hline June - - & .54 & .81 & .90 \\
\hline July & .77 & 1.15 & 1.33 \\
\hline August & .18 & .27 & .30 \\
\hline eptember & .32 & .48 & .53 \\
\hline
\end{tabular}

September

Water year ending September 30, 1974

\begin{tabular}{|c|c|c|c|}
\hline October --_- & 0.32 & 0.48 & 0.56 \\
\hline November -- & 2.10 & 3.13 & 3.49 \\
\hline December --_ & 2.18 & 3.25 & 3.76 \\
\hline January --_- & 4.42 & 6.60 & 7.60 \\
\hline February - - & 2.51 & 3.75 & 3.91 \\
\hline March - & 1.80 & 2.69 & 3.10 \\
\hline April --_- & 2.42 & 3.61 & 4.03 \\
\hline May - & .81 & 1.21 & 1.40 \\
\hline June - & 1.04 & 1.55 & 1.73 \\
\hline July - - & .13 & .19 & .22 \\
\hline August -- & .25 & .37 & .44 \\
\hline September - - - & .67 & 1.00 & 1.12 \\
\hline Mean --_-- & 1.55 & 2.31 & - \\
\hline Total - & --- & -- & 31.36 \\
\hline
\end{tabular}


TABLE 31.-Discharge and runoff at the Helton Branch at Greenwood stream-gaging station Location-Lat. $36^{\circ} 53^{\prime} 07^{\prime \prime}$, long. $84^{\circ} 28^{\prime} 55^{\prime \prime}$. McCreary County, on left bank $250 \mathrm{ft}$ upstream from mouth and

Period of record-January 1956 to September 1974 Gage-Water-stage recorder and concrete control. Datum of gage is $993.8 \mathrm{ft}$ above sea

Average discharge -18 years, $1.22 \mathrm{ft}^{3} / \mathrm{s}, 19.49 \mathrm{in} / \mathrm{yr}$

Extremes-Period of record: Maximum discharge, $182 \mathrm{ft}^{3} / \mathrm{s}$, February 27, 1962 (gage height, $1.45 \mathrm{ft}$ in gage well, from rating curve extended above $65 \mathrm{ft}^{3} / \mathrm{s}$; maximum height, $1.52 \mathrm{ft}$, August 9, 1970; minimum discharge, $0.05 \mathrm{ft}^{3} / \mathrm{s}$, October $2,1956$.

\begin{tabular}{|c|c|c|c|}
\hline \multirow[b]{2}{*}{ Month } & \multirow{2}{*}{$\begin{array}{c}\text { Mean } \\
\text { discharge } \\
\left(\mathrm{ft}^{3} / \mathrm{s}\right)\end{array}$} & \multicolumn{2}{|c|}{ Runoff } \\
\hline & & $\left(\mathrm{ft}^{3} / \mathrm{s}\right) / \mathrm{mi}^{2}$ & $\begin{array}{l}\text { Total } \\
\text { inches }\end{array}$ \\
\hline \multicolumn{4}{|c|}{ Water year ending September 30, 1967} \\
\hline ctober -- & 0.26 & 0.31 & 0.35 \\
\hline November --_- & .84 & .99 & 1.10 \\
\hline December - & 2.46 & 2.90 & 3.34 \\
\hline January ----_- & 1.06 & 1.25 & 1.44 \\
\hline February - - & .95 & 1.12 & 1.16 \\
\hline March - & 4.55 & 5.36 & 6.18 \\
\hline April -- & 1.11 & 1.31 & 1.46 \\
\hline May - & 2.06 & 2.43 & 2.80 \\
\hline June --_- & .85 & 1.00 & 1.12 \\
\hline July --_--_-_- & 2.20 & 2.58 & 2.98 \\
\hline August - & .32 & .38 & .43 \\
\hline September - - & .19 & .22 & .25 \\
\hline Mean - & 1.40 & 1.65 & -- \\
\hline Total --_-_- & --- & --- & 22.61 \\
\hline
\end{tabular}

Water year ending September 30, 1968

\begin{tabular}{|c|c|c|c|}
\hline October -- & .26 & .30 & .35 \\
\hline November -- & .78 & .92 & 1.02 \\
\hline December --_- & 2.37 & 2.78 & 3.21 \\
\hline January - - & 2.03 & 2.38 & 2.75 \\
\hline February -- & .78 & .92 & .99 \\
\hline March - & 3.28 & 3.85 & 4.44 \\
\hline April - - & 2.28 & 2.68 & 2.99 \\
\hline May - & 2.27 & 2.67 & 3.08 \\
\hline June - - & .51 & .60 & .67 \\
\hline July --_--_-_-_- & .17 & .20 & .23 \\
\hline August - & .23 & .27 & .31 \\
\hline September - - & .17 & .20 & .22 \\
\hline - & 1.26 & 1.48 & -1 \\
\hline - & -- & --- & 20.26 \\
\hline
\end{tabular}

Water year ending September 30, 1969

\begin{tabular}{|c|c|c|c|}
\hline October - - & 0.21 & 0.25 & 0.29 \\
\hline November - & .27 & .32 & .3 \\
\hline December -- & .66 & .77 & .89 \\
\hline January --1-0- & .94 & 1.10 & 1.27 \\
\hline February - - & 2.13 & 2.50 & 2.61 \\
\hline March - & .89 & 1.05 & 1.21 \\
\hline April -- & 1.70 & 2.00 & 2.23 \\
\hline May - & .79 & .94 & 1.08 \\
\hline June - - & .36 & .43 & .48 \\
\hline July - - & .31 & .36 & .42 \\
\hline August -- & .24 & .28 & .32 \\
\hline September - - & .30 & .35 & .39 \\
\hline - & 0.73 & 0.86 & - \\
\hline -...-. & --- & --- & 11.53 \\
\hline
\end{tabular}

TABLE 31.-Discharge and runoff at the Helton Branch at Greenwood stream-gaging station-Continued

\begin{tabular}{|c|c|c|}
\hline & & Runoff \\
\hline Month & $\begin{array}{c}\text { discharge } \\
\left(\mathrm{ft}^{3} / \mathrm{s}\right)\end{array}$ & $\begin{array}{lc}\left(\mathrm{ft}^{3} / \mathrm{s}\right) / \mathrm{mi}^{2} & \begin{array}{c}\text { Total } \\
\text { inches }\end{array}\end{array}$ \\
\hline
\end{tabular}

Water year ending September 30,1970

\begin{tabular}{|c|c|c|c|}
\hline tok & .24 & .28 & .33 \\
\hline November -- - & .37 & .44 & .48 \\
\hline December - & 2.44 & 2.87 & 3.31 \\
\hline nuary --------- & .99 & 1.16 & 1.34 \\
\hline February - & 2.62 & 3.08 & 3.21 \\
\hline March - & 1.21 & 1.42 & 1.65 \\
\hline April -1- & .22 & 2.61 & 2.92 \\
\hline May - & .46 & .54 & .63 \\
\hline June --_- & .19 & .22 & .25 \\
\hline July - - - & .16 & .19 & .21 \\
\hline August -- & 1.24 & 1.46 & 1.68 \\
\hline September - & .64 & .75 & .84 \\
\hline - & 1.05 & 1.24 & -0 \\
\hline - & -- & -- & 6.85 \\
\hline
\end{tabular}

Water year ending September 30, 1971

\begin{tabular}{|c|c|c|c|}
\hline October ----_- & 0.73 & 0.86 & 0.99 \\
\hline November --_-_- & 1.19 & 1.40 & 1.56 \\
\hline December -- & 1.69 & 1.99 & 2.30 \\
\hline January --_--_- & 3.16 & 3.72 & 4.28 \\
\hline February -- & 3.57 & 4.20 & 1.38 \\
\hline March -- & 1.39 & 1.64 & .8 \\
\hline April --_- & 1.64 & 1.93 & .1 \\
\hline May - & 1.75 & 2.06 & 2.37 \\
\hline June - - & .26 & .31 & .3 \\
\hline July - - & .66 & .78 &. \\
\hline August - - & .67 & .79 & .9 \\
\hline September -- & .18 & .21 & .2 \\
\hline 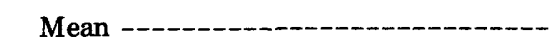 & 1.40 & 1.65 & \\
\hline- & -- & --- & \\
\hline
\end{tabular}

Water year ending September 30, 1972

\begin{tabular}{|c|c|c|c|}
\hline - & .21 & .25 & \\
\hline November - & .24 & .28 & .31 \\
\hline December -- & .46 & .54 & .63 \\
\hline January --- & 3.11 & 3.66 & 4.22 \\
\hline February --- & 4.12 & 4.85 & .23 \\
\hline March - & 2.98 & 3.51 & 4.04 \\
\hline 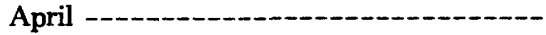 & 4.08 & 4.80 & 5.35 \\
\hline May -- & 1.95 & 2.29 & 2.65 \\
\hline June -- & .28 & .33 & .37 \\
\hline July & .30 & .35 & .4 \\
\hline August -- & .26 & .31 & .3 \\
\hline September - - & .31 & .36 & .4 \\
\hline 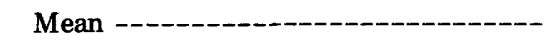 & 1.52 & 1.29 & \\
\hline -...-. & - & -- & 24.2 \\
\hline
\end{tabular}

Water year ending September 30, 1973

\begin{tabular}{|c|c|c|}
\hline 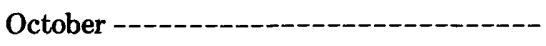 & 0.25 & 0.29 \\
\hline er --n--_- & .65 & .76 \\
\hline 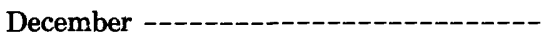 & 3.03 & 3.56 \\
\hline
\end{tabular}


TABLE 31.-Discharge and runoff at the Helton Branch at Greenwood stream-gaging station-Continued

\begin{tabular}{|c|c|c|c|}
\hline \multirow[b]{2}{*}{ Month } & \multirow{2}{*}{$\begin{array}{c}\text { Mean } \\
\text { discharge } \\
\left(\mathrm{ft}^{3} / \mathrm{s}\right)\end{array}$} & \multicolumn{2}{|c|}{ Runoff } \\
\hline & & $\left(\mathrm{ft} \mathrm{t}^{3} / \mathrm{s}\right) / \mathrm{mi}^{2}$ & $\begin{array}{l}\text { Total } \\
\text { inches }\end{array}$ \\
\hline \multicolumn{4}{|c|}{ Water year ending September 30, 1973-Continued } \\
\hline February - - & 2.22 & 2.61 & 2.72 \\
\hline March -- & 3.60 & 4.24 & 4.89 \\
\hline April - - & 2.28 & 2.68 & 3.00 \\
\hline May - - & 3.25 & 3.82 & 4.41 \\
\hline June - - - & 1.00 & 1.18 & 1.32 \\
\hline July - - & 1.73 & 2.04 & 2.35 \\
\hline August -- & .32 & .38 & .43 \\
\hline September --- & .55 & .65 & .72 \\
\hline Mean - & 1.69 & 1.99 & \\
\hline Total -- & --- & --- & 27.04 \\
\hline \multicolumn{4}{|c|}{ Water year ending September 30,1974} \\
\hline October - & .66 & .78 & .90 \\
\hline November --- & 3.39 & 3.99 & 4.45 \\
\hline December --_-_-_-_- & 3.54 & 4.16 & 4.80 \\
\hline January ------_-- & 7.78 & 9.15 & 10.56 \\
\hline February -- & 3.40 & 4.00 & 4.17 \\
\hline March - & 2.02 & 2.38 & 2.74 \\
\hline April ------- & 2.95 & 3.47 & 3.88 \\
\hline May -- & .89 & 1.05 & 1.20 \\
\hline June - - & 1.34 & 1.58 & 1.75 \\
\hline July -- & .28 & .33 & .3 \\
\hline August - & .41 & .48 & .55 \\
\hline September -- & .84 & .99 & 1.10 \\
\hline Mean - & 2.28 & 2.68 & \\
\hline 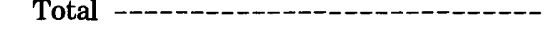 & -- & -- & 36.49 \\
\hline
\end{tabular}

TABLE 32.-Annual maximum discharges for Cane Branch near Parkers Lake

\begin{tabular}{|c|c|c|c|}
\hline \multirow[b]{2}{*}{$\begin{array}{l}\text { Wate } \\
\text { year }\end{array}$} & \multirow[b]{2}{*}{ Date } & \multicolumn{2}{|c|}{ Discharge } \\
\hline & & $\mathrm{ft}^{3} / \mathrm{s}$ & $\left(\mathrm{ft}^{3} / \mathrm{s}\right) \mathrm{mi}^{2}$ \\
\hline 1956 & -- Apr. 6 & 98 & 146 \\
\hline 1957 & --- Jan. 29 & 198 & 296 \\
\hline 1958 & --- Apr. 24 & 154 & 230 \\
\hline 1959 & --- July 19 & 30 & 45 \\
\hline 1960 & --- July 10 & 71 & 106 \\
\hline 1961 & -- Mar. 8 & 44 & 66 \\
\hline 1962 & --- Feb. 27 & 184 & 275 \\
\hline 1963 & --- Mar. 11 & 127 & 190 \\
\hline 1964 & -- Sept. 29 & 27 & 40 \\
\hline 1965 & --- Mar. 29 & 54 & 81 \\
\hline 1966 & --- Mar. 4 & 24 & 36 \\
\hline 1967 & -- Mar. 6 & 151 & 225 \\
\hline 1968 & --- May 26 & 60 & 90 \\
\hline 1969 & --- Apr. 18 & 21 & 31 \\
\hline 1970 & -- Aug. 9 & 236 & 352 \\
\hline 1971 & --- Jan. 4 & 106 & 158 \\
\hline 1972 & --- Feb. 24 & 96 & 143 \\
\hline 1973 & --Dec. 9 & 98 & 146 \\
\hline 1974 & --- Apr. 4 & 82 & 122 \\
\hline
\end{tabular}

TABLE 33.-Annual maximum discharges for Helton Branch at Greenwood

\begin{tabular}{|c|c|c|}
\hline \multirow[b]{2}{*}{$\begin{array}{l}\text { Water } \\
\text { year }\end{array}$} & \multicolumn{2}{|c|}{ Discharge } \\
\hline & $\mathrm{ft}^{3} / \mathrm{s}$ & $\left(\mathrm{ft}^{3} / \mathrm{s}\right) \mathrm{mi}^{2}$ \\
\hline 1956 --- Apr. 6 & 104 & 122 \\
\hline 1957 --- Jan. 29 & 136 & 160 \\
\hline $1958--$ Nov. 18 & 54 & 64 \\
\hline 1959 --- June 2 & 18 & 21 \\
\hline $1960--$ July 10 & 65 & 76 \\
\hline 1961 -- Mar. 8 & 32 & 38 \\
\hline $1962---$ Feb. 27 & 182 & 214 \\
\hline $1963--$ Mar. 11 & ${ }^{1} 130$ & ${ }^{1} 153$ \\
\hline 1964 --- Mar. 8 & 21 & 25 \\
\hline $1965--$ Mar. 29 & 46 & 54 \\
\hline 1966 -- Apr. 28 & 26 & 31 \\
\hline 1967 --- Mar. 6 & 69 & 81 \\
\hline $1968--$ Mar 12 & 36 & 42 \\
\hline $1969---$ May 18 & 10 & 12 \\
\hline $1970---$ Aug. 9 & 122 & 144 \\
\hline 1971 -- Jan. 4 & 67 & 79 \\
\hline $1972---$ Feb. 24 & 54 & 64 \\
\hline 1973 --- May 27 & 76 & 89 \\
\hline $\begin{array}{r}1974 \text {--- Nov. 27, } \\
\text { June } 1\end{array}$ & 67 & 79 \\
\hline
\end{tabular}

TABLE 34.-Annual maximum discharges for West Fork Cane Branch near Parkers Lake

\begin{tabular}{|c|c|c|}
\hline \multirow[b]{2}{*}{$\begin{array}{l}\text { Water } \\
\text { year }\end{array}$} & \multicolumn{2}{|c|}{ Discharge } \\
\hline & $\mathrm{ft}^{3} / \mathrm{s}$ & $\left(\mathrm{ft}^{3} / \mathrm{s}\right) \mathrm{mi}^{2}$ \\
\hline $1956---$ Mar. 14 & ${ }^{1} 92$ & ${ }^{13} 354$ \\
\hline $1957---$ Jan. 29 & 129 & 496 \\
\hline 1958 -- Apr. -- & 65 & 250 \\
\hline 1959 --- July -- & 62 & 238 \\
\hline 1960 --- July -- & 20 & 77 \\
\hline 1961 --- Mar. 8 & 28 & 108 \\
\hline $1962---$ Feb. 27 & 48 & 185 \\
\hline 1963 --- Mar. 11 & 24 & 92 \\
\hline $1964--$ Mar. 8 & 20 & 77 \\
\hline $1965---$ Mar. 29 & 53 & 204 \\
\hline 1966 --- Mar. 4 & 21 & 81 \\
\hline 1967 --- Mar. 6 & 26 & 100 \\
\hline $1968---$ Mar. 12 & 26 & 100 \\
\hline 1969 -- Apr. 18 & 14 & 54 \\
\hline $1970---$ Feb. 15 & 45 & 173 \\
\hline 1971 --- Jan. 4 & 34 & 131 \\
\hline $1972---$ Apr. 12 & 28 & 108 \\
\hline $1973--$ May 28 & 35 & 135 \\
\hline $1974--$ Apr. 4 & 67 & 258 \\
\hline
\end{tabular}


TABLE 35.-Precipitation, in inches, at recording gages, October 1966 to September 1974

\begin{tabular}{|c|c|c|c|c|c|c|}
\hline \multirow{2}{*}{ Month and year } & \multicolumn{3}{|c|}{ Cane Branch basin } & \multicolumn{3}{|c|}{ Helton Branch basin } \\
\hline & Gage 1 & Gage 2 & Average & Gage 5 & Gage 6 & Average \\
\hline \multicolumn{7}{|l|}{1966} \\
\hline October - & 2.15 & 2.33 & 2.24 & 1.44 & 1.58 & 1.51 \\
\hline November - & 4.62 & 4.58 & 4.60 & 3.64 & 4.17 & 3.91 \\
\hline December - & 5.43 & 5.05 & 5.24 & 4.85 & 4.79 & 4.82 \\
\hline \multicolumn{7}{|l|}{1967} \\
\hline 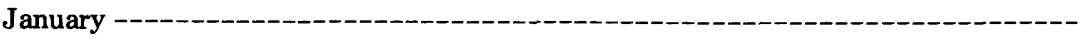 & 2.55 & 2.32 & 2.44 & 1.93 & 1.94 & 1.94 \\
\hline February -- & 2.49 & 2.45 & 2.47 & 1.98 & 2.01 & 2.00 \\
\hline March - & 7.75 & 7.27 & 7.51 & 7.15 & 8.46 & 7.80 \\
\hline Year ending March 31 & 50.80 & 49.49 & 50.14 & 40.83 & 46.57 & 43.73 \\
\hline 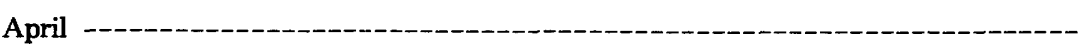 & 4.20 & 3.60 & 3.90 & 3.12 & 3.20 & 3.16 \\
\hline May & 5.26 & 4.92 & 5.09 & 5.37 & 4.27 & 4.82 \\
\hline June - & 5.67 & 5.61 & 5.64 & 5.31 & 4.33 & 4.82 \\
\hline - - - - - - - - - - - - - - - - & 9.70 & 8.92 & 9.31 & 7.21 & 7.97 & 7.59 \\
\hline August - & 3.58 & 3.05 & 3.32 & 3.14 & 2.87 & 3.00 \\
\hline September - & 3.50 & 3.58 & 3.54 & 2.83 & 3.52 & 3.18 \\
\hline Year ending September 30 & 56.90 & 53.68 & 55.29 & $\mathbf{4 7 . 9 7}$ & 49.12 & 48.54 \\
\hline October - & 2.48 & 2.44 & 2.46 & 2.01 & 2.03 & 2.02 \\
\hline November -- - - - & 4.76 & 4.42 & 4.59 & 4.10 & 4.42 & 4.26 \\
\hline December - - & 4.62 & 4.17 & 4.40 & 4.22 & 4.38 & 4.30 \\
\hline \multicolumn{7}{|l|}{1968} \\
\hline January - - - - - - - - & 1.97 & 1.71 & 1.81 & 1.57 & 1.73 & 1.65 \\
\hline 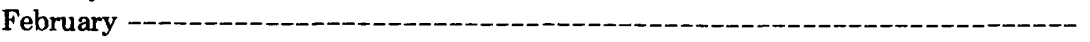 & .37 & .45 & .41 & .27 & .21 & .24 \\
\hline March -- & 6.18 & 6.52 & 6.35 & 6.10 & 6.06 & 6.08 \\
\hline Year ending March 31 & $\underline{52.23}$ & 49.39 & 50.81 & 45.25 & 44.99 & 45.12 \\
\hline April - & 5.00 & 4.65 & 4.82 & 4.29 & 4.44 & 4.36 \\
\hline May & 8.26 & 7.79 & 8.02 & 6.04 & 6.38 & 6.21 \\
\hline - & 2.32 & 2.30 & 2.31 & 2.47 & 1.75 & 2.11 \\
\hline July - - - - - & 2.67 & 2.23 & 2.45 & 2.39 & 1.93 & 2.16 \\
\hline 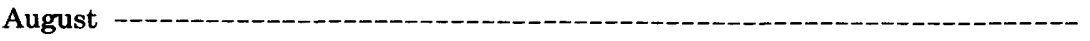 & 2.23 & 1.93 & 2.08 & 3.39 & 3.51 & 3.45 \\
\hline September - - & 2.26 & 2.13 & 2.20 & 2.63 & 2.43 & 2.53 \\
\hline Year ending September 30 & 43.06 & 40.74 & 41.90 & 39.48 & 39.27 & 39.38 \\
\hline October - - - - - - - - - - - - - - - - - - - & 2.58 & 2.48 & 2.53 & 2.83 & 2.88 & 2.86 \\
\hline November -- & 2.43 & 2.29 & 2.36 & 2.79 & 2.58 & 2.68 \\
\hline December - & 3.66 & 3.34 & 3.50 & 2.86 & 2.86 & 2.86 \\
\hline \multicolumn{7}{|l|}{1969} \\
\hline January - - - & 2.58 & 2.54 & 2.56 & 2.22 & 2.32 & 2.27 \\
\hline February - & 3.98 & 2.88 & 3.43 & 2.68 & 2.31 & 2.50 \\
\hline March - - & 1.67 & 1.68 & 1.68 & 1.25 & 1.10 & 1.18 \\
\hline Year ending March 31 & 39.64 & 36.24 & 37.94 & 35.84 & 34.49 & 35.17 \\
\hline April -- & 4.48 & 4.76 & 4.52 & 3.80 & 4.52 & 4.16 \\
\hline May & 3.55 & 3.58 & 3.56 & 2.76 & 3.14 & 2.95 \\
\hline June - & 4.80 & 4.62 & 4.71 & 4.13 & 4.68 & 4.40 \\
\hline 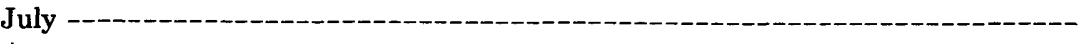 & 3.64 & 3.14 & 3.39 & 2.83 & 2.97 & 2.90 \\
\hline August & 1.61 & 1.51 & 1.56 & 1.49 & 1.25 & 1.37 \\
\hline September - & 3.42 & 3.45 & 3.46 & 3.64 & 4.53 & 4.08 \\
\hline Year ending September 30 & 38.95 & 36.27 & 37.36 & 33.28 & 35.14 & 34.21 \\
\hline October -- & 1.88 & 1.62 & 1.75 & 1.11 & 1.25 & 1.18 \\
\hline November - & 2.53 & 2.49 & 2.51 & 2.28 & 2.39 & 2.34 \\
\hline December -- - & 6.20 & 5.88 & 6.04 & 5.43 & 5.93 & 5.68 \\
\hline
\end{tabular}


TABLF 35.-Precipitation, in inches, at recording gages, October 1966 to September 1974 -Continued

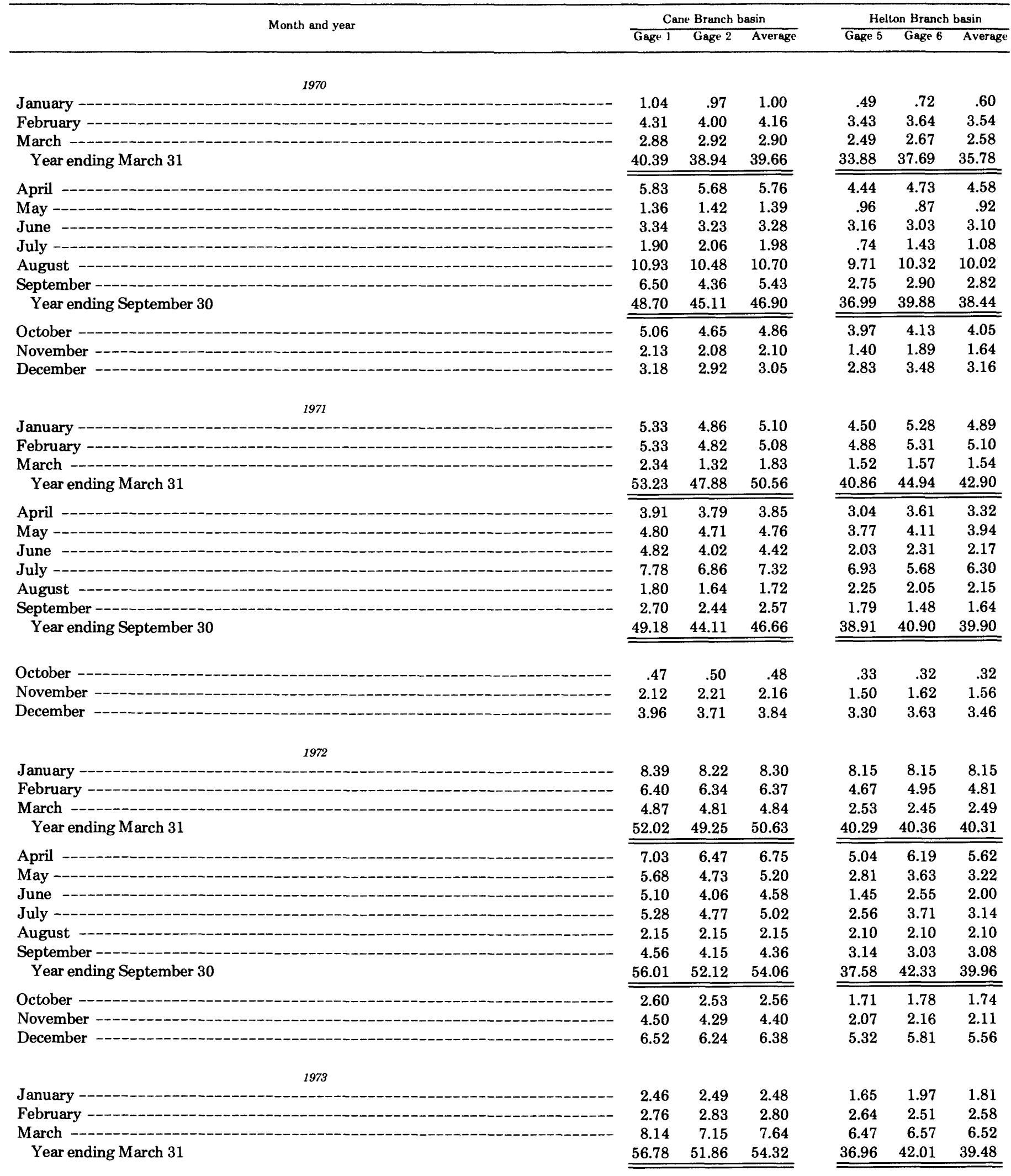


TABlE: 35.-Precipitation, in inches, at recording gages, October 1966 to September 1974-Continued

\begin{tabular}{|c|c|c|c|c|c|c|}
\hline \multirow{2}{*}{ Month and year } & \multicolumn{3}{|c|}{ Cane Branch basin } & \multicolumn{3}{|c|}{ Helton Branch basin } \\
\hline & Gage 1 & Gage 2 & Average & $\overline{\text { Gage } 5}$ & Gage 6 & Average \\
\hline \multicolumn{7}{|l|}{ 1973-Continued } \\
\hline April - & 4.38 & 4.34 & 4.36 & ${ }^{1} 3.77$ & 3.80 & 3.78 \\
\hline May - & 7.09 & 6.48 & 6.78 & 6.52 & 6.49 & 6.50 \\
\hline 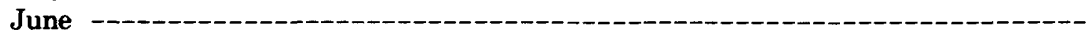 & 5.73 & 4.42 & 5.08 & 3.86 & 4.01 & 3.94 \\
\hline 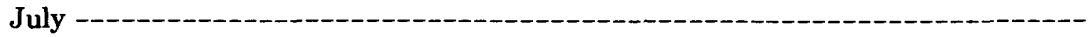 & 6.80 & 5.85 & 6.32 & 7.34 & 6.85 & 7.10 \\
\hline August - & 2.24 & 1.99 & 2.12 & 2.25 & 2.24 & 2.24 \\
\hline September - & 4.86 & 4.12 & 4.49 & 3.85 & 3.74 & 3.80 \\
\hline Year ending September 30 & 58.08 & 52.73 & 55.40 & 47.45 & 47.93 & 47.69 \\
\hline 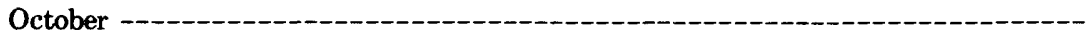 & 4.44 & 4.04 & 4.24 & 3.70 & 3.65 & 3.68 \\
\hline - - - - - - - - - - & 7.00 & 6.21 & 6.60 & 6.30 & 6.30 & 6.30 \\
\hline December -- - - & 4.90 & 4.73 & 4.82 & 4.50 & 4.56 & 4.53 \\
\hline \multicolumn{7}{|l|}{1974} \\
\hline - - - - - - - - - - - - - - & 7.45 & 7.43 & 7.44 & 7.00 & 7.10 & 7.05 \\
\hline February - & 3.90 & 3.85 & 3.88 & 3.49 & 3.84 & 3.66 \\
\hline March - & 4.45 & 4.27 & 4.36 & 4.05 & 4.10 & 4.08 \\
\hline Year ending March 31 & 63.24 & 57.73 & 60.48 & 56.63 & 56.68 & 56.66 \\
\hline - - - - - - - - - - - & 4.45 & 4.57 & 4.51 & 4.31 & 4.35 & 4.33 \\
\hline C-n- & 5.86 & 5.04 & 5.45 & 3.50 & 4.15 & 3.82 \\
\hline June $-1-1-1$ & 5.11 & 4.18 & 4.64 & 3.79 & 3.09 & 3.44 \\
\hline July & 1.13 & .95 & 1.04 & 1.35 & 1.35 & 1.35 \\
\hline August $-(-\infty-1$ & 8.15 & 6.49 & 7.32 & 5.15 & 4.80 & 4.98 \\
\hline September - & 4.62 & 4.00 & 4.31 & 3.60 & 3.00 & 3.30 \\
\hline Year ending September 30 & 61.46 & 53.76 & 58.61 & 50.74 & 50.29 & 50.52 \\
\hline
\end{tabular}

\footnotetext{
${ }^{1}$ Record for gage 5 from April 1973 to September 1974 is estimated from record of gage 6 due to malfunction of gage 5 recorder.
} 
TABLE 36.-Maximum precipitation amounts recorded in Cane Branch basin during selected storms [Maximum precipitation amounts, in inches, for indicated periods based on gage that recorded the greater amount]

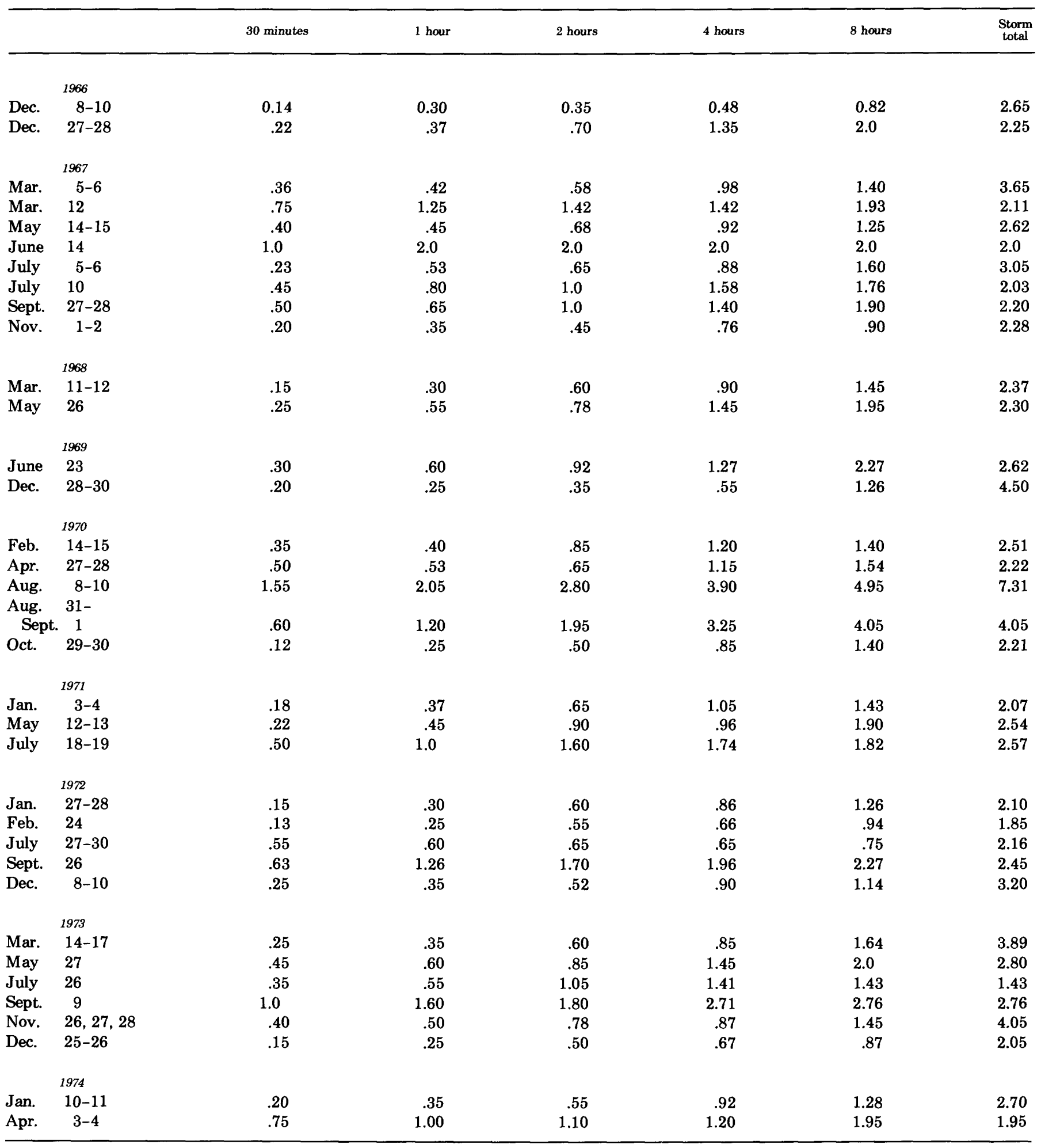




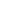


